NELMA ELISA FARIAS KUNRATH ALBANEZ

\title{
PREPARAÇÃO E CARACTERIZAÇÃO DE NANOCOMPÓSITOS PREPARADOS COM ARGILAS ESMECTITAS (BENTONITA), AMIDO E SACAROSE
}




\section{PREPARAÇÃO E CARACTERIZAÇÃO DE NANOCOMPÓSITOS} PREPARADOS COM ARGILAS ESMECTITAS (BENTONITA), AMIDO E SACAROSE

Tese apresentada à Escola Politécnica da Universidade de São Paulo, para obtenção do Título de Doutor em Engenharia.

Área de concentração:

Engenharia Metalúrgica e de Materiais.

Orientador: Professor Dr. Francisco Rolando Valenzuela-Díaz . 


\section{FICHA CATALOGRÁFICA}

Albanez, Nelma Elisa Farias Kunraath

Preparação e caracterização de nanocompósitos preparados com argilas esmectitas (bentonita), amido e sacarose / N.E.F.K. Albanez. -- São Paulo, 2008.

p.

Tese (Doutorado) - Escola Politécnica da Universidade de São Paulo. Departamento de Engenharia Metalúrgica e de Materiais.

1. Argilas (Características; Aplicações) 2. Argilas (Tratamento químico) I. Universidade de São Paulo. Escola Politécnica. Departamento de Engenharia Metalúrgica e de Materiais II. t. 


\section{Nelma Elisa Farias Kunrath Albanez}

Formada em Química Industrial, pela Universidade Federal de Santa Maria RS (UFSM/RS) no ano de 1980. Mestre em Ciências na Área de Tecnologia Nuclear Básica, pelo Instituto de Pesquisas Energéticas e Nucleares (IPENCNEN/USP) no ano de 1996, com o trabalho intitulado: "Obtenção de Óxido de Cério com Alta Área Superficial Específica", orientada pelo Dr. José Carlos Bressiani. 


\section{AGRADECIMENTOS}

Ao professor Dr. Francisco Rolando Valenzuela-Díaz, pelo seu empenho na orientação deste Doutorado e acima de tudo pela sua compreensão.

Aos amigos, Valquíria Kozievitch, Carolina Pinto, Guilermo Ruperto Martín Cortés, Kleberson Pereira, Wilson pela amizade, carinho e apoio dispensados à minha pessoa, principalmente às amigas Miriam de Abreu e Shirley Cosin, que me incentivaram em todos os momentos.

Aos colegas do Laboratório de Matérias-Primas Particuladas e Sólidos Não Metálicos (LMPSol).

Aos professores da Escola Politécnica de Engenharia Metalúrgica e de Materiais que contribuíram com seus conhecimentos e equipamentos para a execução deste trabalhos. Aos amigos que estiveram e estão ao meu lado, principalmente quando preciso de mais atenção.

À minha família. Meu marido e meus filhos.

A todos, que de alguma forma, contribuíram para a realização deste trabalho. 
"O valor de todo o conhecimento está no seu vínculo com as nossas necessidades, aspirações e ações; de outra forma, o conhecimento torna-se um simples lastro de memória, capaz apenas - como um navio que navega com demasiado peso - de diminuir a oscilação da vida quotidiana." V. O. Kliutchevski 


\section{A meu marido \\ Ant oni o Apareci do Al banez.}

\section{Meus filhos}

Daniel

Bruno

Minha gratidão por participarem da minha vida.

Raul

Com muita saudade, sempre presente em nossos corações. 


\section{RESUMO}

A necessidade de materiais modernos, isto é, com características diferenciadas, é cada vez maior e tornou muito grande a pesquisa por novos materiais. Nos últimos anos materiais carbonáceos têm sido utilizados na sorção em estações de tratamento de águas residuais. A desvantagem apresentada por esses materiais é o seu alto custo. Para a obtenção dos nanocompósitos, utilizaram-se materiais de baixo custo: argila chocolate proveniente do Estado da Paraíba, Brasil, amido de milho e sacarose. Para diminuir o custo do carvão ativado estudaram-se compostos do mesmo com bentonita. As amostras foram tratadas termicamente a $110^{\circ} \mathrm{C}, 350^{\circ} \mathrm{C}, 500^{\circ} \mathrm{C}$, $700^{\circ} \mathrm{C}$ e $900^{\circ} \mathrm{C}$. Os materiais obtidos foram estudados por Difração de raios $\mathrm{X}$ DRX, Análises Térmicas e microscopia eletrônica de varredura - MEV. Foi avaliada a sua capacidade de sorção de azul de metileno. Obteve-se nanocompósitos para todas as concentrações de amido e para concentrações iniciais de $5 \%$ e $10 \%$ de sacarose. Os materiais que apresentaram melhor capacidade de sorção foram os formados pela argila e carvão ativado em pó. Percebeu-se, também, a influência da temperatura de secagem da argila. À medida que aumenta a temperatura, a capacidade de sorção diminui. Os valores de adsorção obtidos com as amostras contendo amido de milho foram em torno de $200 \mathrm{mg} / \mathrm{g}$ de sorvente e, no caso do carvão ativado em torno de $400 \mathrm{mg} / \mathrm{g}$, mas os materiais derivados de amido podem apresentar potencial de uso devido ao baixo custo do amido com relação ao carvão ativo. 


\begin{abstract}
The need of modern materials, that is, with differentiated characteristics, is bigger every time and it turned very big the research for new materials. In the recent years carbonaceous material has been used to sorption action in sorption stations in wastewater treatment plant. The disadvantage presented by those materials is its high cost. For the attainment of the nanocomposite, they had been used low cost material: clay "chocolate" from the State of the Paraíba, Brazil, corn starch and sucrose. To decrease the cost of the activated coal they were studied composites of the same with bentonite. Samples had been thermally treated by $110^{\circ} \mathrm{C}, 350^{\circ} \mathrm{C}, 500^{\circ} \mathrm{C}, 700^{\circ} \mathrm{C}$ and $900^{\circ} \mathrm{C}$. The gotten materials had been studied by X - Ray Difraction - DRX, Thermal Analyses and scanning electronic microscopy - MEV. It was assessed for its ability to sorption of methylene blue. It was obtained nanocomposite for all the concentrations of starch and for initial concentrations of $5 \%$ and $10 \%$ of sucrose. The materials that presented better sorption capacity were formed them by the clay and powdered activated coal. It was noticed, too, the influence of temperature for drying the clay. As the temperature increases, the ability to sorption decreases. The adsorption values obtained with the samples contend corn starch they were about of $200 \mathrm{mg} / \mathrm{g}$ of sorptive and, in the case of the coal activated about of 400 $\mathrm{mg} / \mathrm{g}$, but the derived materials of starch can present potential of use due to the low cost of the starch with relationship to the active coal.
\end{abstract}




\section{SUMÁRIO}

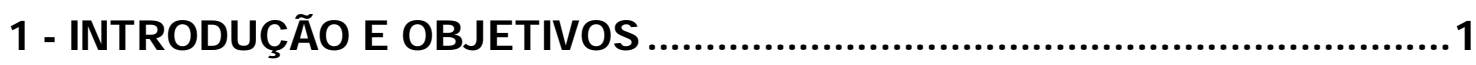

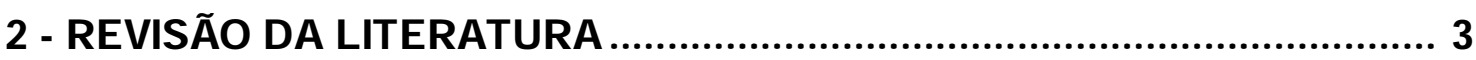

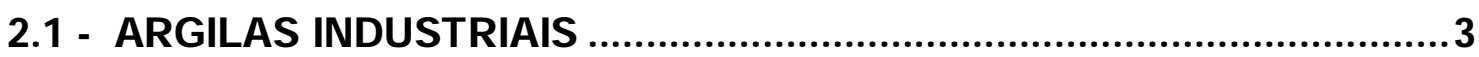

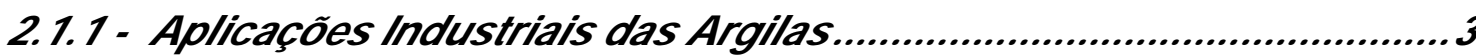

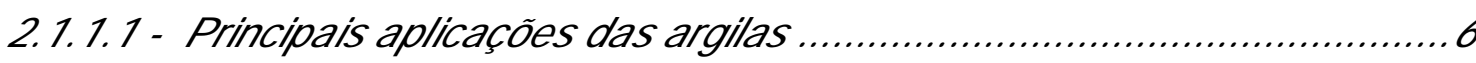

2.2 - BENTONITAS (ARGILAS ESMECTÍTICAS) .................................... 8

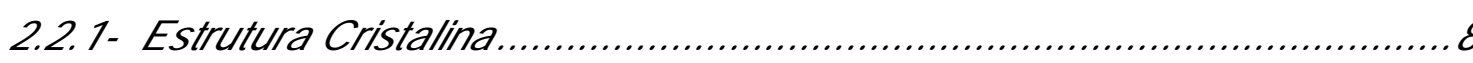

2.2.2 - Nomenclatura dos Argilominerais ...............................................13

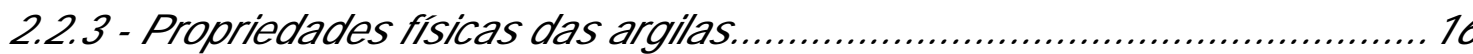

2.2.4 Alguns comentários sobre a água nas Argilas, sua natureza, seu papel16

2.2.5 - Argilas Bentoníticas do Estado da Paraíba .........................................18

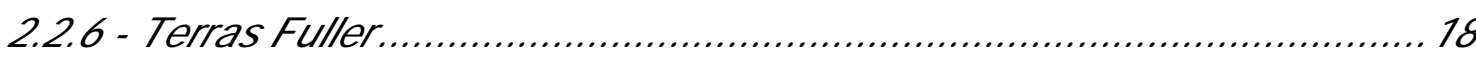

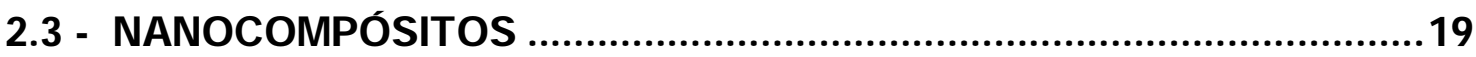

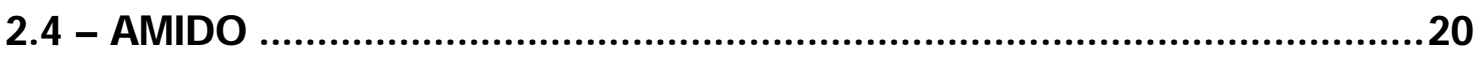

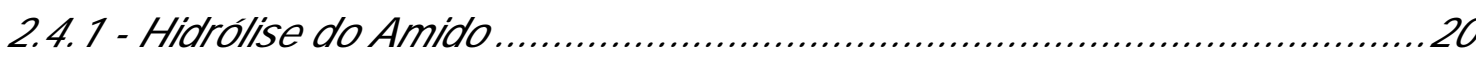

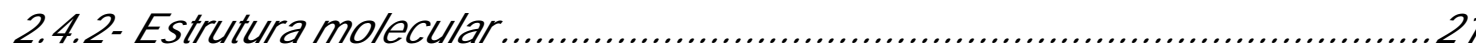

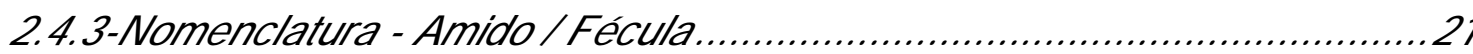

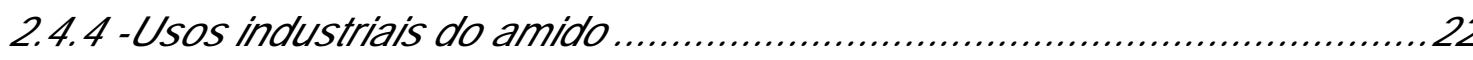

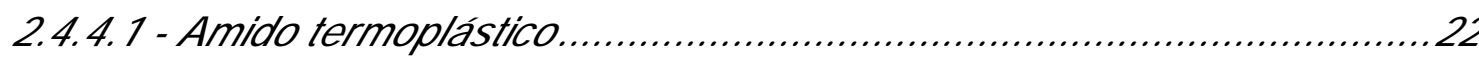

2.4.4.2 - Preparação de compósitos a base de amido …................................24

2.4.4.3 - Preparação de espumas a base de amido- fécula de mandioca........24

2.4.4.4- Preparação de filmes biodegradáveis a base de amido .....................24

2.4.4.5 - Preparação de filmes e polímeros amido/bentonita ............................23

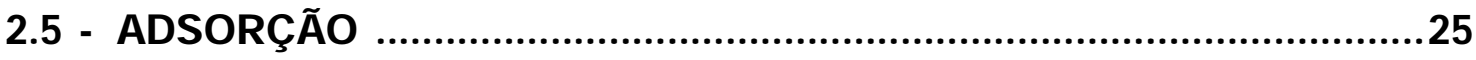

2.5.1 - Determinação da área superficial específica......................................22

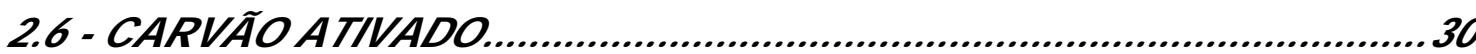


2.6.1 - Compósitos Argila/Material Carbonoso 31

3. MATERIAIS E MÉTODOS 33

3.1 - MATERIAIS 33

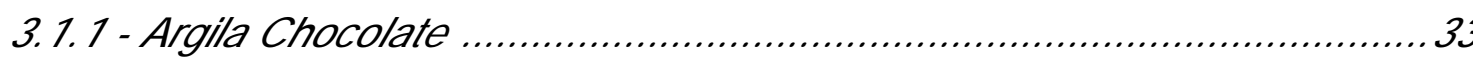

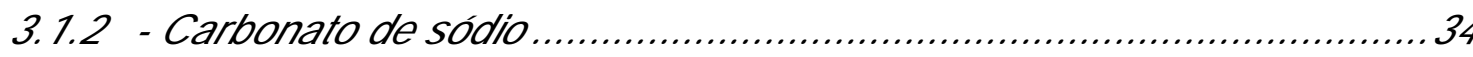

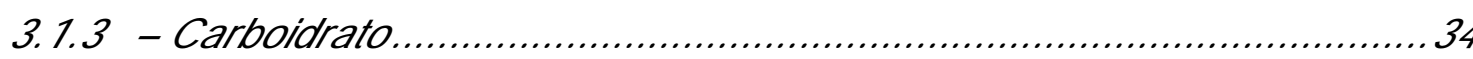

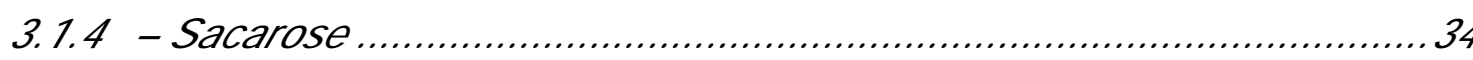

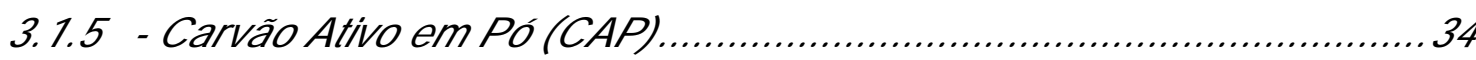

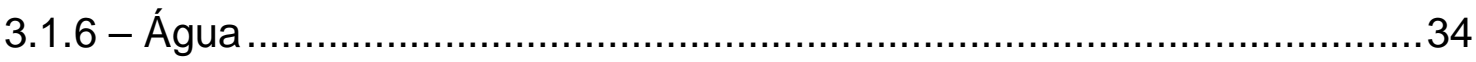

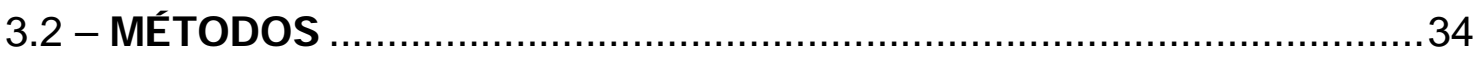

3.2.1 - Método de preparo do compósito Argila/Amido e Argila/Sacarose e

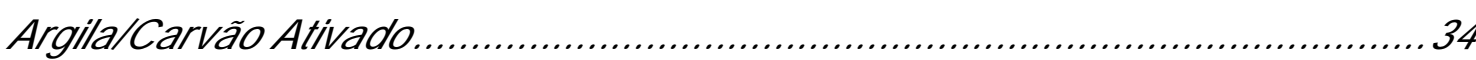

3.2.1.1 - Obtenção da Argila Sódica a Partir da Bentonita Policatiônica ........... 35

3.2.1.1 - Preparação dos Nanocompósitos à base de amido ............................36

3.2.1.2 - Preparação dos Nanocompósitos à base de sacarose ...................... 39

3.2.1.3-P reparação dos Compósitos à base de carvão ativado ....................... 42

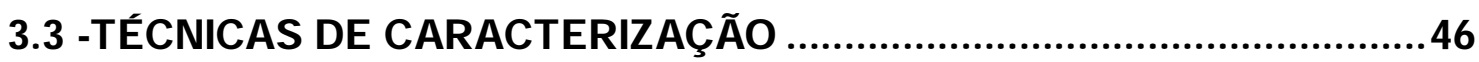

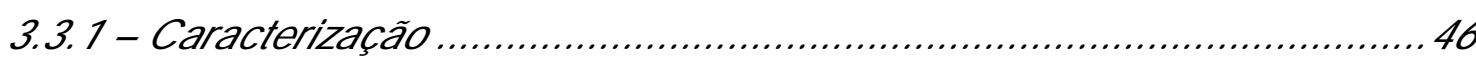

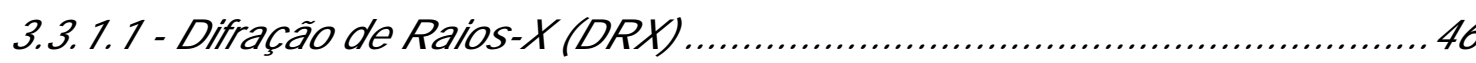

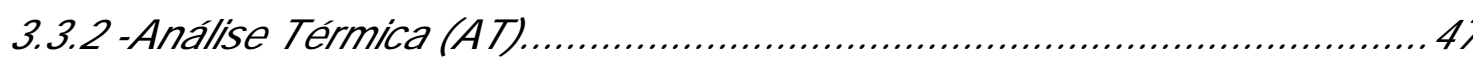

3.3.3 - Microscopia Eletrônica de Varredura (MEV) ........................................47 
3.3.4 - Capacidade de sorção - Sorção (Ad/absorção) de Azul de Metileno (AM) 48

3.3.5 - Espectrofotometria 49

3.3.6 - Área superficial específica 49

4 - RESULTADOS E DISCUSSÃO 46

4.1 MÉTODOS DE CARACTERIZAÇÃO 46

4.1.1 - Viscosidade 50

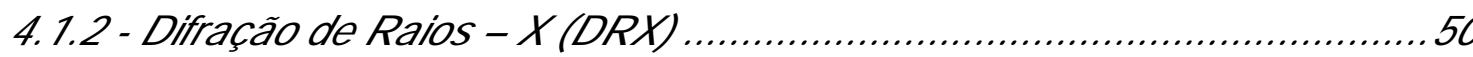

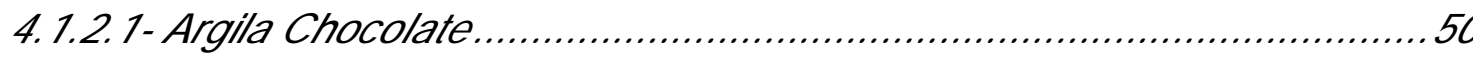

4.1.2.2 Nanocompósitos de argila chocolate com amido de milho ..................51

4.1.2.3 Nanocompósitos de argila chocolate com sacarose........................54

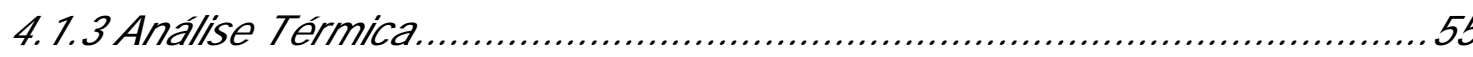

4.1.3.1 .Nanocompósitos de argila chocolate com carvão ativado ..................56

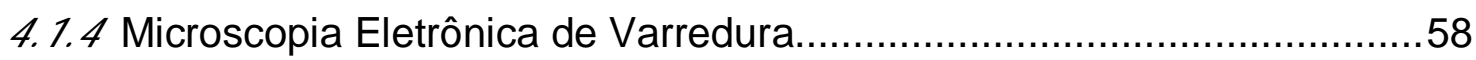

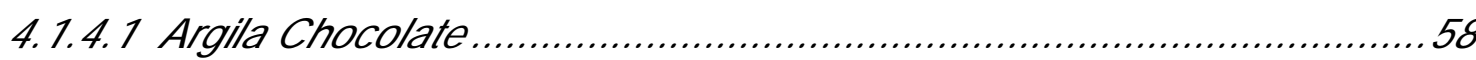

4.1.4.2 Nanocompósitos de argila chocolate com amido de milho ................60

4.1.4.3 Nanocompósitos de argila chocolate com sacarose $\ldots \ldots \ldots \ldots \ldots \ldots \ldots \ldots . \ldots . \ldots \ldots$

4.1.4.4 Nanocompósitos de argila chocolate com carvão ativado ...................64 64

4.1.5 Sorção (ad/absorção) de Azul de Metileno (AM) ............................... 71

4.1.5.1 Nanocompósitos de argila chocolate com amido de milho .................. 71

4.1.5.2 Nanocompósitos de argila chocolate com sacarose ........................73

4.1.5.3 Compósitos de argila chocolate com carvão ativado......................... 74 


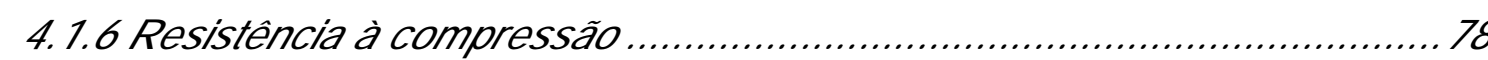

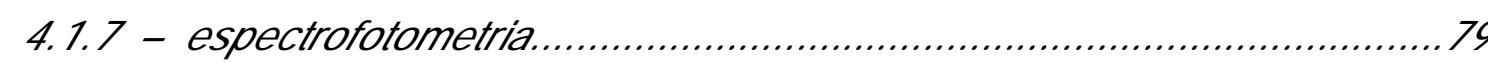

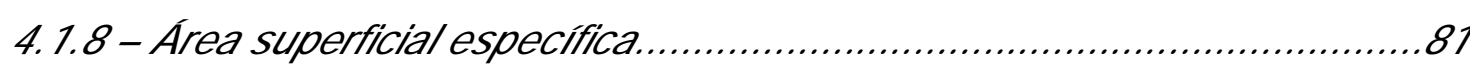

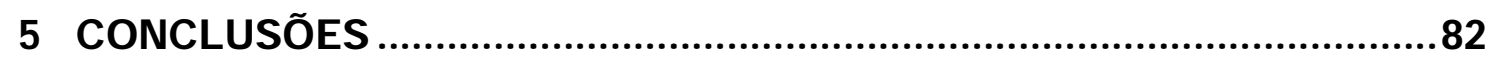

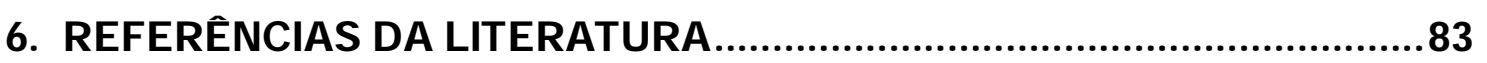

6. SUGESTÕES PARA TRABALHOS FUTUROS .................................. 91 


\section{LISTA DE FIGURAS}

Figura 1 - estrutura cristalina da argila bentonita [USGS].

Figura 2 - Tetraedros de silício/oxigênio formando as folhas tetraédricas e os octaedros de alumínio / hidroxila formando as folhas octaédricas [José, 2003].

Figura 3 - (a) Representação de um octaedro constituído de um átomo de alumínio (Al), que pode ser substituído por ferro (Fe) ou magnésio $(\mathrm{Mg})$ central e seis hidroxilas $(\mathrm{OH})$ nos vértices. (b) Representação da folha octaédrica vista de lado [Batista, 2006].

Figura 4 - Representação da estrutura de uma partícula do tipo 2:1. (a) Forma tridimensional. (b) Forma esquemática [Batista, 2006].

Figura 5 - formação do amido.

Figura 6 - estrutura do amido. a) amilose, b) amilopectina

Figura 7 - Argila Chocolate. Acima e esquerda: argila moída no moinho de facas. Acima e direita: a mesma argila moída manualmente e peneirada (passante na malha ABNT $n^{\circ} 20$ e retida na malha 100). Abaixo: ainda a mesma argila moída manualmente e peneirada (passante na peneira $\mathrm{ABNTn}^{\circ} 100$ ).

Figura 8 - fluxograma do processo de obtenção dos nanocompósitos argila chocolate /amido de milho; argila chocolate /sacarose e argila chocolate/carvão ativado.

Figura 9 - dispersão aquosa formada pela argila chocolate policatiônica e 36 carbonato de sódio.

Figura 10 - corpos esféricos compostos por argila e carvão ativado.

Figura 11 - adsorção de azul de metileno. Adsorvato: carvão ativado, 
compósitos argila/carvão ativado (83\% em massa de carvão).

Figura 12 - curva de raios- $X$ da argila chocolate queimada a $500^{\circ} \mathrm{C} \mathrm{p} / 30$ $\min$

Figura 13 - curva de raios-X de DRX do nanocompósito argila chocolate/amido de milho - amostra D-5 (10\% de amido em relação à massa de argila), queimada a $500^{\circ} \mathrm{C}$ por $30 \mathrm{~min} .1$

Figura 14 - curva de raios-X de DRX do nanocompósito argila chocolate/amido de milho - amostra E-5 (20\% de amido em relação à massa de argila), queimada a $500^{\circ} \mathrm{C}$ por $30 \mathrm{~min}$.

Figura 15 - curva de raios-X de DRX do nanocompósito argila chocolate/sacarose - amostra ASS-B (5\% de sacarose em relação à massa de argila), queimada a $500^{\circ} \mathrm{C}$ por $30 \mathrm{~min}$.

Figura 16 - curva de raios-X de DRX do nanocompósito argila 54 chocolate/sacarose - amostra ASS-D (10\% de sacarose em relação à massa de argila), queimada a $500^{\circ} \mathrm{C}$ por $30 \mathrm{~min}$.

Figura 17 - amostra 3 (carvão ativado genérico 83\%), seca a $110^{\circ} \mathrm{C}$ por 56 24 horas

Figura 18 - amostra 7, (carvão ativado genérico 83\%), queimada a 56 $350^{\circ} \mathrm{C}$ por $30 \mathrm{~min}$.

Figura 19 - amostra 10 (carvão ativado genérico 83\%), queimada a 57 $500^{\circ} \mathrm{C}$ por $30 \mathrm{~min}$.

Figura 20 - amostra 14 (carvão ativado genérico 83\%), queimada a 57 $750^{\circ} \mathrm{C}$ por $30 \mathrm{~min}$.

Figura 21 - amostra 18 (carvão ativado genérico 83\%), queimada a 57 $900^{\circ} \mathrm{C}$ por $30 \mathrm{~min}$.

Figura 22 - micrografia da argila chocolate, seca a $60^{\circ} \mathrm{C}$ por 24 horas. 
Figura 23 - micrografia da argila chocolate, seca a $100^{\circ} \mathrm{C}$ por 24 horas.

Figura 24 - micrografia da argila chocolate, queimada a $500^{\circ} \mathrm{C}$.

Figura 25 - difratograma de EDS da argila chocolate, natural, queimada a 60 $500^{\circ} \mathrm{C}$.

Figura 26 - micrografia do nanocompósito argila/amido de milho - 60 amostra D-5 (10\% de amido em relação à massa de argila, queimada a $500^{\circ} \mathrm{C}, 30 \mathrm{~min}, 10 \% \mathrm{~min}$.)

Figura 27 - difratograma de EDS do nanocompósito argila 61 chocolate/amido de milho - amostra D-5 (10\% de amido em relação à massa de argila), queimada a $500^{\circ} \mathrm{C}$ por $30 \mathrm{~min}$.

Figura 28 - micrografia do nanocompósito argila/amido de milho - 61 amostra E-5 (20\% de amido em relação à massa de argila, queimada a $500^{\circ} \mathrm{C}, 30 \mathrm{~min}, 10^{\circ} / \mathrm{min}$.).

Figura 29 - difratograma de EDS do nanocompósito argila 62 chocolate/amido de milho - amostra E-5 (20\% de amido em relação à massa de argila), queimada a $500^{\circ} \mathrm{C}$ por $30 \mathrm{~min}$.

Figura 30 - micrografia do nanocompósito argila/sacarose - amostra 52 ASS- B $(5,0 \%$ de sacarose em relação à massa de argila, queimada a $500^{\circ} \mathrm{C}, 30 \mathrm{~min}, 10 \% \mathrm{~min}$.).

Figura 31 - difratograma de DRX do nanocompósito argila 63 chocolate/sacarose - amostra ASS-B (5\% de sacarose em relação à massa de argila), queimada a $500^{\circ} \mathrm{C}$ por $30 \mathrm{~min}$.

Figura 32 - micrografia do nanocompósito argila/sacarose - amostra ASS- D ( $10 \%$ de sacarose em relação à massa de argila, queimada a $500^{\circ} \mathrm{C}, 30 \mathrm{~min}, 10^{\circ} / \mathrm{min}$.).

Figura 33 - difratograma de EDS do nanocompósito argila 
chocolate/sacarose - amostra ASS-D (10\% de sacarose em relação à massa de argila), queimada a $500^{\circ} \mathrm{C}$ por $30 \mathrm{~min}$.

Figura 34 - micrografia do carvão ativado em pó, marca VETEC.

Figura 35 - difratograma de EDS do carvão ativado em pó, marca VETEC

Figura 36 - micrografia do compósito argila/carvão ativado em pó amostra 8 (83\% de carvão ativado em pó em relação à massa de argila, queimada a $350^{\circ} \mathrm{C}, 30 \mathrm{~min}, 10^{\circ} / \mathrm{min}$.).

Figura 37 - difratograma de EDS do compósito argila chocolate/carvão ativado - amostra 8 (83\% de carvão ativado em relação à massa de argila), queimada a $350^{\circ} \mathrm{C}$ por $30 \mathrm{~min}$.

Figura 38 - micrografia do compósito argila/carvão ativado em pó amostra 10 (83\% de carvão ativado em pó em relação à massa de argila, queimada a $500^{\circ} \mathrm{C}, 30 \mathrm{~min}, 10^{\circ} / \mathrm{min}$.).

Figura 39 - difratograma de EDS do compósito argila chocolate/carvão ativado - amostra 10 (83\% de carvão ativado em relação à massa de argila), queimada a $500^{\circ} \mathrm{C}$ por $30 \mathrm{~min}$.

Figura 40 - micrografia do compósito argila/carvão ativado em pó amostra 22 (75\% de carvão ativado em pó em relação à massa de argila, queimada a $500^{\circ} \mathrm{C}$, sem patamar, $10^{\circ} \mathrm{C} / \mathrm{min}$.).

Figura 41 - difratograma de EDS do compósito argila/carvão ativado em pó - amostra 22 (75\% de carvão ativado em pó em relação à massa de argila, queimada a $500^{\circ} \mathrm{C}$, sem patamar, $10^{\circ} \mathrm{C} / \mathrm{min}$.).

Figura 42 - micrografia do compósito argila/carvão ativado em pó - 68 amostra 25 (75\% de carvão ativado em pó em relação à massa de argila, queimada a $750^{\circ} \mathrm{C}$, sem patamar, $10^{\circ} \mathrm{C} / \mathrm{min}$.). 
Figura 43 - difratograma de EDS do compósito argila/carvão ativado em 69 pó - amostra 25 (75\% de carvão ativado em pó em relação à massa de argila, queimada a $750^{\circ} \mathrm{C}$, sem patamar, $10^{\circ} \mathrm{C} / \mathrm{min}$.).

Figura 44 - micrografia do compósito argila/carvão ativado em pó - 69 amostra 28 (75\% de carvão ativado em pó em relação à massa de argila, queimada a $900^{\circ} \mathrm{C}$, sem patamar, $10^{\circ} \mathrm{C} / \mathrm{min}$.).

Figura 45 - difratograma de EDS do nanocompósito argila/carvão 70 ativado em pó - amostra 28 (75\% de carvão ativado em pó em relação à massa de argila, queimada a $900^{\circ} \mathrm{C}$, sem patamar, $10^{\circ} \mathrm{C} / \mathrm{min}$.). 0

Figura 46 - valores da absorbância do azul de metileno. 


\section{LISTA DE TABELAS}

Tabela 1 - Argilominerais mais importantes industrialmente.

Tabela 2 - Esquema adaptado das classificações de Brown de 1955, e 13 de Mackenzie de 1959.

Tabela 3 - Argilominerais 2:1 [antigamente 2:2] (tetramórficos); com 13 camada de hidróxidos intercalada, clóricos ferro - alumino magnesiano, segundo Warshaw e Roy (1967)..

Tabela 3 - Argilominerais 2:1 [antigamente 2:2] (tetramórficos); com 14 camada de hidróxidos intercalada, clóricos ferro - alumino magnesiano, segundo Warshaw e Roy (1967)..

Tabela 4 - Classificação e nomenclatura das cloritas segundo Hey 15 (1954).

Tabela 5 - Esquema de classificação para os filossilicatos relacionados 15 com os argilominerais (Bailey et al., 1971).

Tabela 6 - Classificação dos Argilo - minerais.

Tabela 7 - Composição percentual das dispersões contendo argila e amido

Tabela 8 - Nomenclatura das amostras obtidas pela mistura da argila 38 sódica com amido.

Tabela 9 - Composição percentual da dispersão contendo argila e amido.

Tabela 10 - Composição percentual das dispersões contendo argila e sacarose.

Tabela 11 - Nomenclatura das amostras obtidas pela mistura da argila 41 sódica com sacarose.

Tabela 12 - Composição percentual da dispersão contendo argila e sacarose 
Tabela 13- Nomenclatura das amostras obtidas pela mistura da argila 42 sódica com sacarose.

Tabela 14 - Temperaturas de queima das amostras argila-carvão ativado, procedimento $A$..

Tabela 15 - Temperaturas de queima das amostras argila-carvão ativado, procedimento $B$.

Tabela 16 - Medidas de viscosidade 50

Tabela 17 - Distância Basal das amostras contendo argila chocolate e argila chocolate / amido de milho.

Tabela 18 - Distância Basal das amostras contendo argila chocolate e argila chocolate / sacarose.

Tabela 19 - Resultados dos ensaios de adsorção de azul de metileno pela argila chocolate.

Tabela 20 - Resultados dos ensaios de adsorção de azul de metileno, 71 referentes ao procedimento $A$ (amido em gel).

Tabela 21 - Resultados dos ensaios de adsorção de azul de metileno, 72 referentes ao procedimento $B$ (amido em pó)

Tabela 22 - Resultados dos ensaios de adsorção de azul de metileno 73 pelos nanocompósitos argila chocolate/sacarose.

Tabela 23 - Resultados dos ensaios de adsorção de azul de metileno por carvão ativado.

Tabela 24 - Resultados dos ensaios de adsorção de azul de metileno 75 pelos compósitos argila chocolate/carvão ativado genérico, procedimento $A$.

Tabela 25 - Resultados dos ensaios de adsorção de azul de metileno 76 pelos compósitos argila chocolate/carvão ativado Vetec, procedimento B. 
compostas por argila chocolate sódica e carvão ativado em pó.

Tabela 27 - valores da absorbância da argila chocolate e de alguns 80 compósitos argila chocolate/amido, argila chocolate/sacarose e argila chocolate/carvão ativado. 


\section{1 - INTRODUÇÃO E OBJ ETIVOS}

Os complexos Mineral/Material Carbonoso (CMMCs) são um novo tipo de materiais com alto potencial de uso em ab/adsorção. As suas características são uma textura porosa, com alta área específica, aliada a uma superfície em parte apolar (a parte coberta com material carbonoso) e em parte polar (superfície de silicato não recoberta), com o qual pode adsorver vários tipos de adsorvatos.

No Laboratório de Matérias-Primas Particuladas e Sólidos Não Metálicos (LMPSol), têm sido desenvolvidas várias pesquisas nesta linha. Em estudos efetuados por Valenzuela-Díaz e colaboradores, na década de 1990, verificouse que dispersões de argilas esmectíticas intercalada com sacarose, após secagem a $90 \stackrel{\circ}{\circ}$, apresentavam cor preta. Por ensaios de DRX, constatou-se a intercalação do composto orgânico entre as lamelas de argila. Após queima a $350^{\circ} \mathrm{C}$ e atmosfera redutora, o material apresentou poder de adsorção de azul de metileno. Foram então testados, no LMPSol, diversos tipos de substratos (argilas comuns, caulinitas, amianto, vermiculitas, paligorsquita e sílica-gel), visando observar se aconteceria o mesmo fenômeno (carbonização do açúcar a $90 \stackrel{\circ}{\circ}$ ). Entre os materiais preparados os que tiveram resultados mais satisfatórios foram os realizados com argilas esmectíticas e sílica-gel.

A dissertação da Eng. Daniela dos Reis Raimundo (Departamento de Engenharia Química da EPUSP, orientada do professor Francisco R. Valenzuela-Díaz) teve como tema "O estudo da influência da concentração dos xaropes de partida em complexos argilas esmectíticas-sacarose". As concentrações de sacarose utilizadas para preparar os xaropes foram de $1,0 \%$; $5,0 \% ; 10,0 \% ; 20,0 \% ; 30,0 \% ; 40,0 \% ; 50,0 \%$ e $60,0 \%$ em massa de sacarose em relação à massa de argila e duas argilas: bentonita norte-americana naturalmente sódica, e uma argila esmectítica brasileira natural, policatiônica.

A dissertação do Eng. José Reis Herney Ramírez Franco (Departamento de Engenharia Química da EPUSP, orientado do professor Francisco $R$. Valenzuela-Díaz) teve como tema "A obtenção de CMMCs, a base de argila/ sacarose; argila/refugo industrial e argila/sílica-gel". A argila utilizada foi uma 
esmectítica nacional e as concentrações de sacarose foram: 2,5\%; 5,0\%; 7,5\%; 10,0\% em massa de sacarose em relação à argila.

Os nanocompósitos silicato / material carbonoso são um novo tipo de materiais com amplo potencial de uso e, baseando-se nos estudos efetuados no LMPSol decidiu-se, que o objetivo da Tese de Doutorado da Química Industrial Nelma Elisa Farias Kunrath Albanez seria:

- Preparar e caracterizar nanocompósitos argila esmectítica / material carbonoso já estudados no LMPSol, partindo da argila bentonita chocolate proveniente de Boa Vista no estado da Paraíba e de amido (2,5\%; 5,0\%; 10\%; $20 \%$ e 30\% em massa de amido em relação à massa da argila).

- Preparar e caracterizar nanocompósitos argila esmectítica / material carbonoso já estudados no LMPSol, partindo da argila bentonita chocolate proveniente de Boa Vista no estado da Paraíba e de sacarose $(2,5 \% ; 5,0 \%$ e $10 \%$ em massa de sacarose em relação à massa da argila).

Assim o objetivo deste trabalho é verificar a incorporação do material carbonoso (amido, sacarose, carvão ativado em pó) na argila esmectítica proveniente do estado da Paraíba e caracterizar por DRX, IV, Sorção de resíduos líquidos tóxicos (fenol, gasolina, etc) e de azul de metileno, termogravimetria, microscopia eletrônica de varredura, granulometria e porcentagem de carbono. 


\section{2 - REVISÃO DA LITERATURA}

\section{$2.1 \quad-\quad$ ARGILAS INDUSTRIAIS}

A utilização da argila remonta ao princípio da civilização, colaborando para satisfazer as suas necessidades de habitação, alimentação, vestuário e estética. As argilas fazem parte de quase todos os tipos de solo e também podem ser encontradas no estado puro em depósitos minerais [Luna, 1999; Valenzuela-Díaz, 1992 e 1994].

O termo argila é utilizado para identificar uma rocha finamente dividida, constituída essencialmente ou exclusivamente por argilominerais cristalinos (partículas $<2$ micrômetros). Este material adquire, quando combinado com água, certa plasticidade, formando uma pasta suficientemente homogênea passível de ser modelada/moldada, que endurece à medida que vai secando peças verdes - e que se transformam em cerâmica através da ação do fogo [Romero, 2006].

Quimicamente os argilominerais são formados essencialmente por silicatos hidratados de alumínio, ferro e magnésio. Caulins, bentonitas, ball clays, argilas refratárias, flints-clays e terras fuller são tipos especiais de argilas industriais que têm definições particulares e podem apresentar variações, quer devido ao emprego tecnológico da argila, quer devido à origem geológica ou à composição mineralógica da argila [Souza, 1992].

Argilas Industriais são argilas que, após extração, beneficiamento e processamento industrial, são utilizadas como matérias-primas nas Indústrias de Processamento Químico [Valenzuela-Díaz, 1992].

\subsubsection{Aplicações Industriais das Argilas}

Com base na definição de que "argila é uma rocha constituída essencialmente por argilominerais, o prof. R. E. Grim, estabeleceu o seguinte 
princípio: "A aplicação industrial de uma argila depende da natureza e das propriedades do argilomineral (ou argilominerais) que é o componente essencial dessa argila, bem como dos cátions trocáveis da mesma. Em conseqüência, os minerais acessórios ou detritais que acompanham o argilomineral, usualmente denominados "impurezas" somente afetam as propriedades da argila pelo seu teor ponderal, geralmente como um diluente inerte do argilomineral [Valenzuela-Díaz, 1992 e 1994].

O grande número de usos industriais das argilas é a conseqüência de um conjunto de propriedades que são específicas para as argilas e que outras rochas (ou minerais) não os possuem simultaneamente, excetuando-se, talvez, as zeólitas. Estas propriedades são as seguintes:

a. As argilas são constituídas por argilominerais, os quais compreendem vários grupos que incluem diversas espécies mineralógicas que são esses argilomierais, diferentes entre si.

b. As diversas espécies mineralógicas apresentam composições químicas diferentes entre si, quer devido às estruturas cristalinas diferentes (silicatos de alumínio ou magnésio hidratados), quer devido às substituições isomórficas (por exemplo, $\mathrm{Al}^{3+}$, substituindo $\mathrm{Si}^{4+} \mathrm{e}$ $\mathrm{Fe}^{3+}$ substituindo $\mathrm{Mg}^{2+}$ ) quer devido aos cátions trocáveis (por exemplo, $\mathrm{Na}^{+}, \mathrm{K}^{+}, \mathrm{Mg}^{2+}, \mathrm{Ca}^{2+}, \mathrm{H}_{3} \mathrm{O}^{+}, \mathrm{Fe}^{3+}, \mathrm{Al}^{3+}$ ).

c. As diversas espécies mineralógicas apresentam propriedades físicoquímicas variando numa faixa ampla de valores (por exemplo): capacidade de troca de cátions entre $3 \mathrm{meq} / 100 \mathrm{~g}$ de argila e 150 meq/100g), uma baixa granulometria natural, passam totalmente na peneira ABNT n 325 de 44 micrômetros de abertura; têm forma anisométrica das partículas (lamelar ou tubular-fibrilar) com a relação diâmetro/espessura (placas) ou comprimento/diâmetro (fibras) variando numa faixa ampla de valores.

d. As argilas são rochas naturalmente subdivididas, isto é, não precisam ser moídas para se obter a individualização das partículas (cristais) já normalmente menores que 44 micrômetros; é necessário apenas uma desaglomeração, que é muito mais barata que a moagem. Assim, as argilas apresentam área superficial externa das partículas muito grande, as quais são encontradas somente em produtos industriais 
caros, como negros-de-fumo e catalisadores de craqueamento. É importante notar que certos argilominerais têm também uma área específica adicional e peculiar entre as camadas lamelares estruturais 2:1 (pois são filossilicatos), como é o caso das esmectitas ou em canais abertos da estrutura cristalina como é o caso das sepiolitaspaligorsquitas. Por essa razão as argilas têm uma "atividade superficial" natural muito grande, pois sua área específica pode se encontrar usualmente na faixa de $5 \mathrm{~m}^{2} / \mathrm{g}$ (caulins) a $200 \mathrm{~m}^{2} / \mathrm{g}$ (esmectitas). Além disso, sua área específica pode ser aumentada em muitos casos quer por tratamentos térmicos, quer por ácidos inorgânicos.

e. As argilas sendo produto da alteração de rochas por ação de intemperismo deutérico ou hidrotérmico e depois transportadas, são constituintes de sedimentos fluviolacustres; por isso estão frequentemente próximas às comunidades humanas atuais, isto é: onde há água superficial, há argilas em quantidade.

f. As Indústrias de Processamento Químico exigem matérias-primas com propriedades mais constantes possíveis. As argilas podem ocorrer em depósitos grandes e bastante homogêneos. As impurezas geralmente minerais detritais - são facilmente separáveis, porque têm geralmente uma granulometria bastante acima da peneira № 325 de 44 micrômetros.

g. As argilas são facilmente dispersáveis em água (e em outros solventes) podendo dar suspensões quer instáveis, quer estáveis, com uma faixa ampla de propriedades reológicas, como viscosidade e plasticidade.

Os minerais específicos das argilas são os denominados argilominerais. Os mais importantes industrialmente estão citados na tabela 1. 
Tabela $1 \quad$ - $\quad$ Argilominerais mais importantes industrialmente

\begin{tabular}{|l|l|}
\hline I.1 & Grupo de caulinita: caulinita e haloisita \\
\hline I.2 & Grupo das serpentinas: amianto, crisotila; antigorita \\
\hline II.1 & Grupo do talco-pirofilita: talco e pirofilita \\
\hline II.2 & Grupo das micas: mica moscovita; sericita e ilita; biotita, lepidolita \\
\hline II.4 & $\begin{array}{l}\text { Grupo das esmectitas: montmorilonita propriamente dita; saponita; } \\
\text { Gontronita; hectorita. }\end{array}$ \\
\hline II.5 & Grupo das cloritas: não tem uso industrial \\
\hline II.6 & $\begin{array}{l}\text { Grupo da paligorsquita (ex-atapulgita)/sepiolita: ambos argilominerais - } \\
\text { paligorsquita e sepiolita }\end{array}$ \\
\hline II.7 & \begin{tabular}{l} 
Camadas mistas: ilita-montmorilonita e montmorilonita-vermiculita \\
\hline III
\end{tabular} \\
\hline
\end{tabular}

\subsubsection{1 - Principa is aplicações das argilas}

Pôr sua diversidade de emprego as argilas comportam uma matériaprima mineral de grande campo de aplicação [Cortés, 1998]. A Indústria moderna possui empresas que utilizam argilas de diversos tipos:

- a indústria da cerâmica vermelha (tijolos, telhas, ladrilhos de piso, lajes e material ornamental);

- a indústria de cerâmica branca (material sanitário, louça doméstica, azulejos e pastilhas, porcelana doméstica, de laboratório e técnica); de material refratário (silico - aluminosos e aluminosos); 
- a indústria de cerâmicas especiais para aplicar na indústria elétrica e eletrônica;

- a indústria da aeronáutica e do espaço para proteção dos modernos aviões e naves espaciais;

- as indústrias de borrachas, plásticos, produtos cosméticos e farmacêuticos que as utilizam como cargas ativas e inertes;

- as indústrias de papel e de papelão que utilizam argilas como carga e como cobertura;

- a indústria metalúrgica, que usa argilas como aglomerantes de areias de moldagem para a fundição de metais e para peletização de minérios de ferro;

- as argilas são também utilizadas como clarificantes de caldo de cana de açúcar, conhaques, licores, vinhos e bebidas em geral; clarificante e depurante de águas; diluentes para inseticidas e pesticidas, como agentes descorantes de óleos vegetais e óleos minerais derivados de petróleo, graxas animais, de papeis e de tecidos;

- como agente tixotrópico em lamas para a perfuração de poços de sondagem (para petróleo, minerais sólidos, água e para a construção civil);

- como espessante de adesivos, esmaltes, e vernizes;

- como impermeabilizantes de barragens, canais, concretos e solos; na produção de películas impermeáveis;

- as argilas são também empregadas em catalisadores no "craqueamento" de petróleo para a produção de gasolina, e assim muitos outros empregos como pôr exemplo na manufatura de minas de lápis, como carga para sabão e tecidos, e na fabricação de cimentos e de produtos farmacêuticos.

Resumindo, as argilas são matérias-primas sólidas com amplas possibilidades de aplicações industriais, por serem abundantes, apresentarem granulometria extremamente fina, além de serem baratas. Contudo, nem todo argilomineral tem uso ou importância industrial. A seguir, serão apresentadas as principais características das bentonitas, o tipo de argila utilizada em esta Tese. 


\section{2 - BENTONITAS (ARGILAS ESMECTÍTICAS)}

Em 1898, Knight sugeriu o termo bentonita para identificar um material argiloso, procedente de "Benton Shale" (Wyoming, EUA). Em 1917, Hewett definiu bentonita como sendo um produto da alteração de cinzas vulcânicas. Em 1926, Ross Y Shannon, usaram este termo para designar: "uma rocha composta essencialmente por um material cristalino, semelhante a uma argila, formado pela desvitrificação e alteração de um material ígneo vítreo, usualmente cinzas vulcânicas".

Atualmente, a definição mais aceita é dada por R. E. Grim (1972): "Bentonita é uma argila composta essencialmente por minerais do grupo das esmectitas, (montmorilonita propriamente dita, beidelita; nontronita; saponita; hectorita) independente de sua origem geológica [Grim, 1978; Valenzuela-Díaz, 1992].

O grupo de argilas com maior variedade de empregos industriais é o da bentonita (argilas esmectíticas) devido as suas propriedades físico-químicas.

\subsection{1 - Estrutura Cristalina}

Os argilominerais do grupo das esmectitas (antigo grupo das montmorilonitas) são constituídos por duas folhas de silicatos tetraédricas, com uma folha central octaédrica (camadas 2:1), unidas entre si por oxigênios comuns às folhas. As folhas são contínuas nas direções dos eixos a e b e estão empilhadas umas sobre as outras com maior ou menor ordem segundo 0 tipo de argilomineral esmectítico. As camadas 2:1 estão ligadas frouxamente entre si e moléculas de água podem penetrar entre elas, separando-as e podendo-as deixar livres (quando a distância interplanar atinge valores superiores a $40,0 \AA$ ).

Pode haver substituições isomórficas em porcentagem moderada (até cerca de 15\%) de silício por ferro e alumínio nas posições tetraédricas e para as posições octaédricas pode ocorrer substituição do alumínio por ferro e magnésio, isoladamente ou em combinação. Todas as posições octaédricas (das seis posições por cela unitária) podem ser preenchidas (formas trioctaédricas: saponita, sauconita e hectorita), ou somente dois terços delas podem estar preenchidas (formas dioctaédricas: montmorilonita, beidelita, nontrolnita, volconscoita). Dadas as substituições isomórficas, as camadas 2:1 
ficam desequilibradas eletricamente, com uma deficiência de cargas positivas de cerca de 0,66 cátion monovalente por cela unitária; deficiência esta que é equilibrada por cátions hidratados entre as camadas estruturais, principalmente $\mathrm{Na}^{+}, \mathrm{Ca}^{2+}, \mathrm{K}^{+}, \mathrm{Al}^{3+}, \mathrm{H}_{3} \mathrm{O}^{+}$e $\mathrm{Fe}^{3+}$. [Grim, 1978].

As figuras 1, 2, 3 e 4 mostram a representação da estrutura cristalina das argilas bentonitas (antigo grupo da montmorilonita).

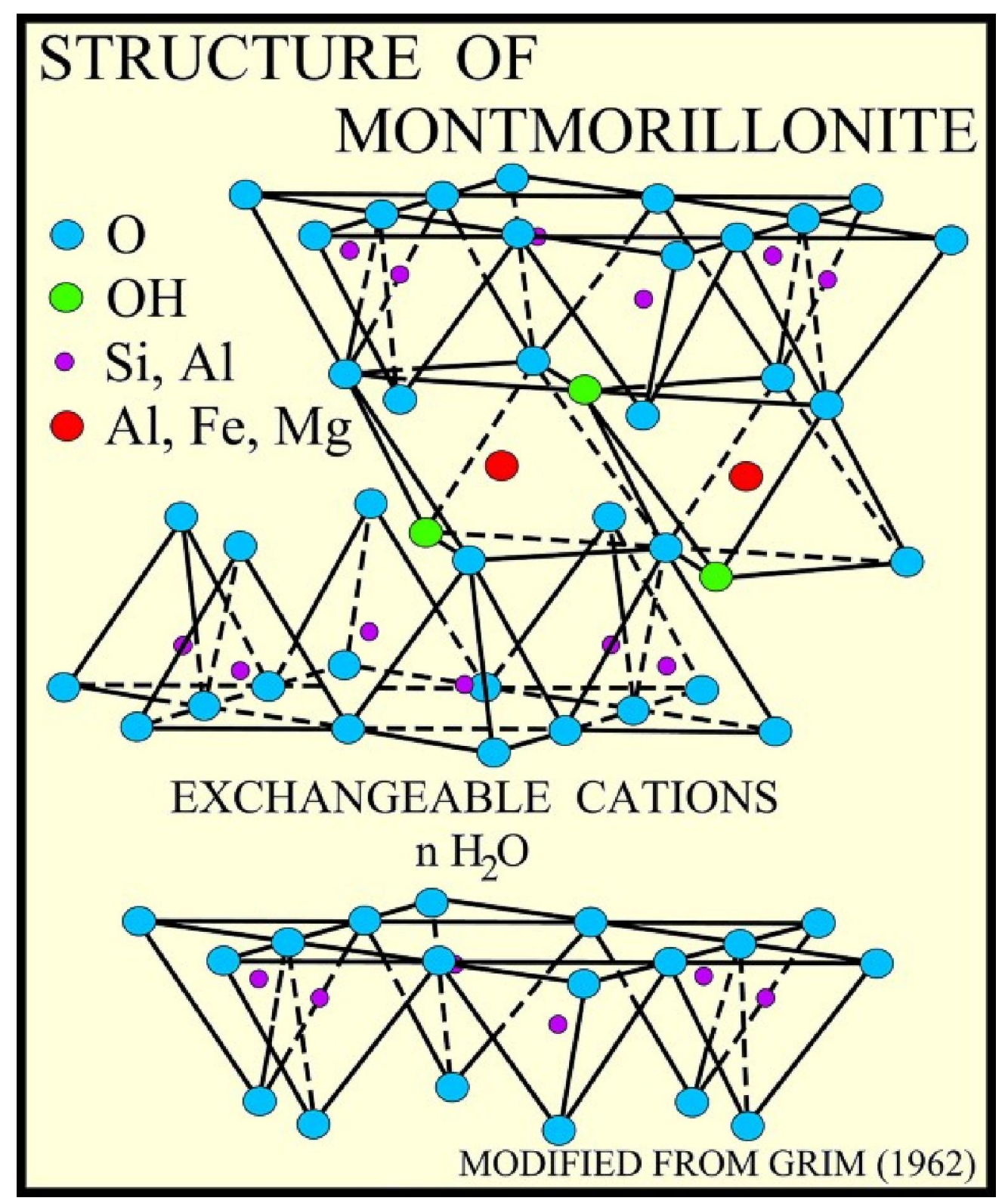

Figura 1 - estrutura cristalina da argila bentonita [USGS]. 
Os argilominerais esmectíticos mais importantes, do ponto de vista industrial, são: montmorilonita propriamente dita, nontronita, saponita e hectorita, sendo a montmorilonita dita a esmectita mais freqüentemente encontrada em depósitos com tonelagem de interesse comercial [Franco, 2003].

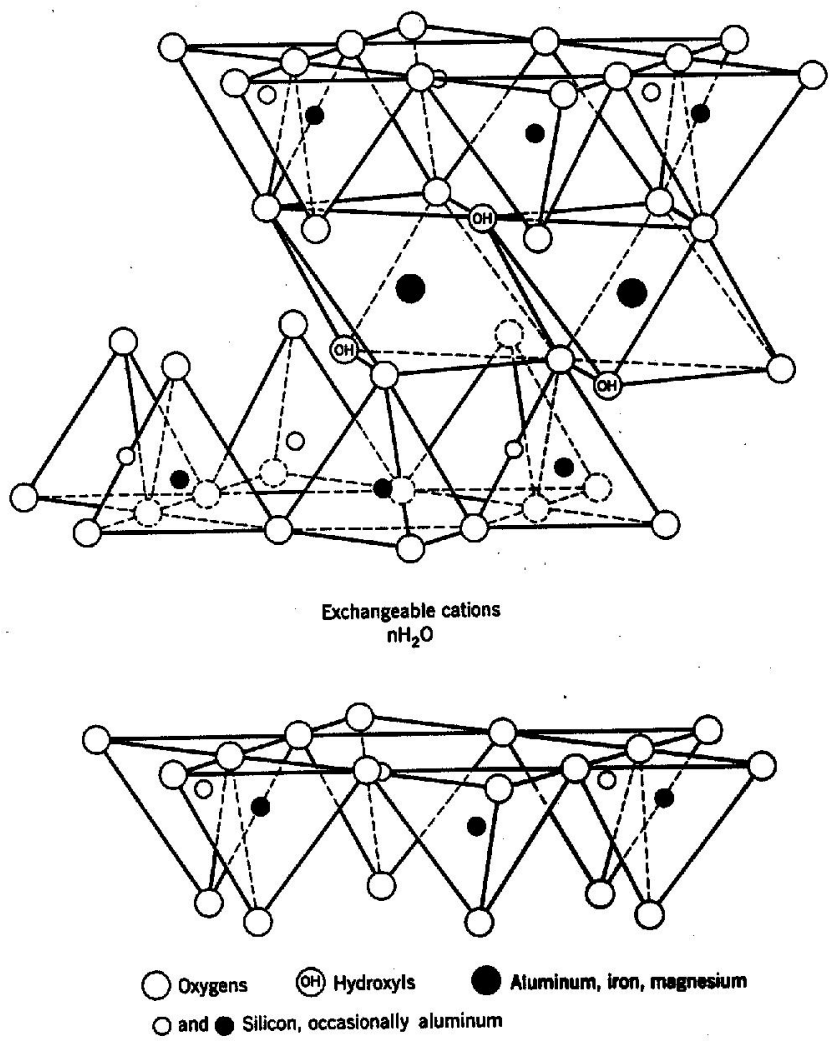

Figura 2 - Tetraedros de silício/oxigênio formando as folhas tetraédricas e os octaedros de alumínio / hidroxila formando as folhas octaédricas [José, 2003].

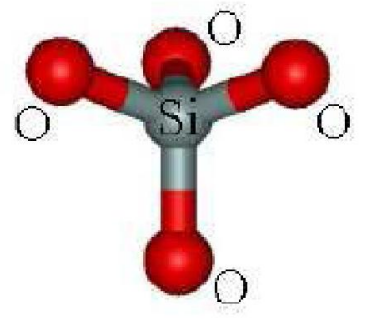

(a)

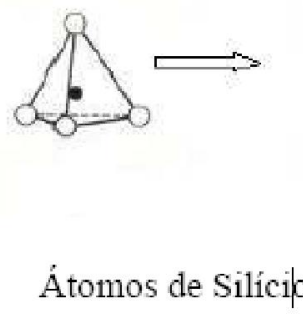

$\bullet$

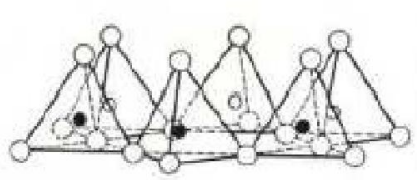

Átomos de oxigênio

(b) 
Figura 2 - (a) Representação de um tetraedro constituído de um átomo de silício (Si) central e quatro átomos de oxigênio $(\mathrm{O})$ nos vértices. (b)

Representação da folha tetraédrica vista de lado [Batista, 2006].

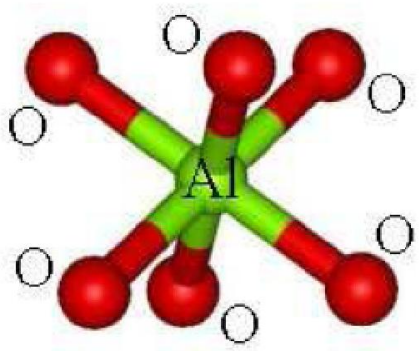

(a)

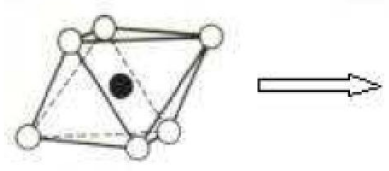

Átomos de Alumínio, Magnésio ou Ferro

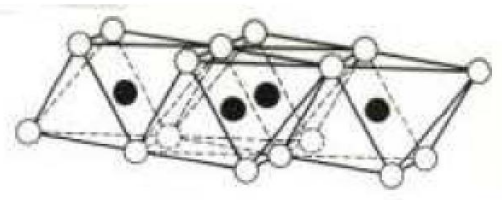

Átomos de Hidroxila

(b)

Figura 3 - (a) Representação de um octaedro constituído de um átomo de alumínio (Al), que pode ser substituído por ferro $(\mathrm{Fe})$ ou magnésio $(\mathrm{Mg})$ central e seis hidroxilas $(\mathrm{OH})$ nos vértices. (b) Representação da folha octaédrica vista de lado [Batista, 2006].

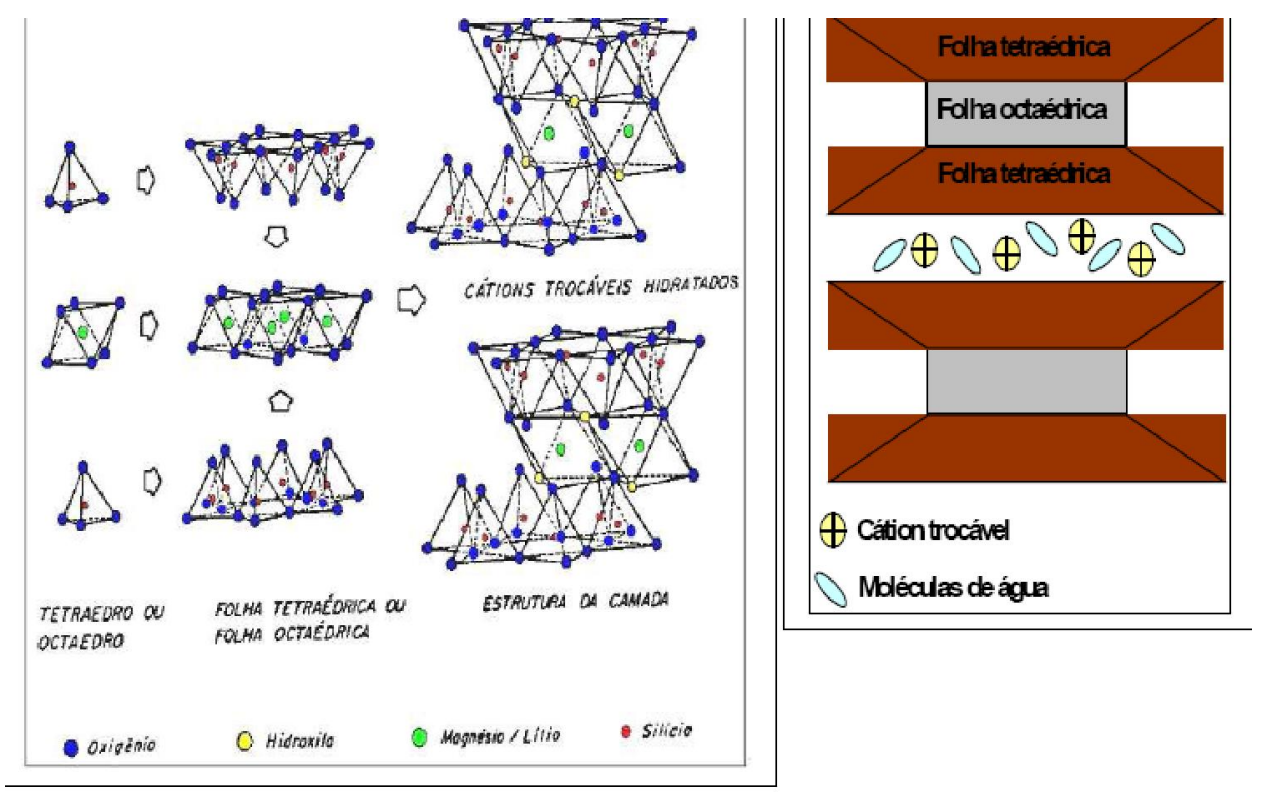

Figura 4 - Representação da estrutura de uma partícula do tipo 2:1. (a) Forma tridimensional. (b) Forma esquemática [Batista, 2006].

A capacidade de troca de cátions (CTC) e os cátions trocáveis dos argilominerais constituem variáveis muito importantes para a determinação das propriedades industriais das bentonitas. Essas argilas são chamadas 
homoiônicas ou monocatiônicas quando um tipo de cátion constitui a maior parte dos cátions trocáveis $\left(\mathrm{Na}^{+}, \mathrm{Ca}^{2+}, \mathrm{K}^{+}, \mathrm{Mg}^{2+}, \mathrm{Ni}^{2+}\right.$ ) e heterocatiônicas ou policatiônicas quando há diferentes proporções significativas dos vários cátions. As bentonitas mais freqüentes são: a) homocatiônica em sódio (por exemplo: bentonitas de Wyoming, EUA), b) homocatiônica em cálcio (por exemplo bentonitas de Mississipi, EUA), c) policatiônicas (a maioria das ocorrências, como é o caso das bentonitas de Campina Grande, Paraíba).

As bentonitas sódicas apresentam, geralmente, inchamentos de Foster [Foster, 1955] em água, maiores a $8 \mathrm{~mL} / \mathrm{g}$ e dispersões viscosas e tixotrópicas, com dispersões a 6\%, em massa de argila, apresentando viscosidades aparentes Fann de $15 \mathrm{cP}$ ou superiores [Souza, 1992] . Elas são usadas como componentes tixotrópicos de fluídos para perfuração de poços de petróleo e água [Wright, 1992], ligantes para areias para moldes e fundição de peças metálicas [Bolger, 1996], ligantes para minérios de ferro e manganês [Wright, 1992], granulados para disposição de rejeitos de animais domésticos [O’Driscoll, 1992], impermeabilização de lagos e disposição de materiais tóxicos [Harries-Rees, 1993], matéria-prima para argilas organofílicas [Reck, 1992], componentes de rações animais [Saeed, 1996], entre outros usos.

As bentonitas cálcicas e as policatiônicas não incham em água apresentam inchamento de Foster na ordem de $3 \mathrm{~mL} / \mathrm{g}$ e dispersões aquosas a $6 \%$, em massa, apresentando viscosidades aparentes Fann de $2 \mathrm{cP}$. Elas são usadas principalmente como ligantes em areias de fundição [Bolger, 1996], para obtenção de bentonitas que incham com água; por meio de reação química de troca catiônica com carbonato de sódio [Souza, 1992] e para obtenção de argilas ativadas com ácidos inorgânicos, para a produção industrial de argilas para descoramento de óleos [Santarém, 1993].

No Brasil e em outros países onde não há bentonitas naturalmente sódicas, utiliza-se carbonato de sódio para sua transformação. Em 1993, no LMPSOL, laboratório da Escola Politécnica de Engenharia da USP, foi desenvolvido um novo método de troca de cátions: troca a quente [ValenzuelaDíaz, 1994]. 


\subsection{2 - Nomenclatura dos Argilominerais}

Os principais argilominerais conhecidos, isto é, cuja estrutura cristalina é experimentalmente bem conhecida, entram no esquema de classificação apresentado a seguir. Contudo não existe ainda uma única classificação para os argilominerais devido ao fato dos especialistas no campo utilizarem critérios diferentes na subdivisão dos diversos grupos [Cortés, 1998].

Tabela 2 - Esquema adaptado das classificações de Brown de 1955, e de Mackenzie de 1959.

\begin{tabular}{|c|c|c|c|}
\hline Classe geral & Grupo & Argilominerais & Fórmula geral \\
\hline $\begin{array}{l}\text { Silicatos } \\
\text { em camadas } \\
\text { ou } \\
\text { lamelares } \\
1: 1\end{array}$ & Caulinita & \begin{tabular}{|l|} 
Nacrita \\
Diquita \\
Caulinita \\
Haloisita. $2 \mathrm{H}_{2} \mathrm{O}$ \\
Haloisita. $4 \mathrm{H}_{2} \mathrm{O}$ \\
Anauxita \\
\end{tabular} & $\begin{array}{l}\mathrm{Al}_{2} \mathrm{Si}_{2} \mathrm{O}_{5}(\mathrm{OH})_{4} \\
\mathrm{Al}_{2} \mathrm{Si}_{2} \mathrm{O}_{5}(\mathrm{OH})_{4} \\
\mathrm{Al}_{2} \mathrm{Si}_{2} \mathrm{O}_{5}(\mathrm{OH})_{4} \\
\mathrm{Al}_{2} \mathrm{Si}_{2} \mathrm{O}_{5}(\mathrm{OH})_{4} \\
\mathrm{Al}_{2} \mathrm{Si}_{2} \mathrm{O}_{5}(\mathrm{OH})_{4} 2 \mathrm{H}_{2} \mathrm{O} \\
\mathrm{Al}_{2} \mathrm{Si}_{3} \mathrm{O}_{7}(\mathrm{OH})_{4}(?)\end{array}$ \\
\hline $\begin{array}{l}\text { Silicatos } \\
\text { em camadas } \\
\text { ou } \\
\text { lamelares } \\
1: 1\end{array}$ & Septocloritas & $\begin{array}{l}\text { Antigorita } \\
\text { Crisotila } \\
\text { Amesita } \\
\text { Cronstedtita } \\
\text { Bertierina }\end{array}$ & $\begin{array}{l}\mathrm{Mg}_{6} \mathrm{Si}_{4} \mathrm{O}_{10}(\mathrm{OH})_{8} \\
\mathrm{Mg}_{6} \mathrm{Si}_{4} \mathrm{O}_{10}(\mathrm{OH})_{8} \\
(\mathrm{Mg}, \mathrm{Fe})_{4} \mathrm{Al}_{4} \mathrm{Si}_{2} \mathrm{O}_{10}(\mathrm{OH})_{8} \\
\mathrm{FeO}_{2} \mathrm{O}_{10}(\mathrm{OH})_{8}\left(\mathrm{Si}_{3} \mathrm{Al}\right) \mathrm{O}_{10}(\mathrm{OH})_{8} \\
\left(\mathrm{Fe}^{2+}, \mathrm{Fe}^{3+}, \mathrm{Mg}, \mathrm{Al}\right)_{6}\left(\mathrm{Si}{ }_{3} \mathrm{Al}\right) \mathrm{O}_{10}(\mathrm{OH})_{8}\end{array}$ \\
\hline $\begin{array}{l}\text { Silicatos } \\
\text { em camadas } \\
\text { ou } \\
\text { lamelares. } \\
2: 1\end{array}$ & $\begin{array}{l}\text { Montmorilonita } \\
\text { (vide nota) }\end{array}$ & $\begin{array}{l}\text { Beidelita } \\
\text { Nontronita } \\
\text { Volconscoita } \\
\text { Montmorilonita } \\
\text { Saponita } \\
\text { Sauconita } \\
\text { Hectorita }\end{array}$ & $\begin{array}{l}0,33 \mathrm{M}^{+} \mathrm{Al}_{2}\left(\mathrm{Si}_{3,67} \mathrm{Al}_{0,33}\right) \mathrm{O}_{10}(\mathrm{OH})_{2} \\
0,33 \mathrm{M}^{+} \mathrm{Fe}_{2}\left(\mathrm{Si}_{3,67} \mathrm{Al}_{0,33}\right) \mathrm{O}_{10}(\mathrm{OH})_{2} \\
0,33 \mathrm{M}^{+}(\mathrm{Fe}, \mathrm{Cr}, \mathrm{Al})_{2}(\mathrm{Si}, \mathrm{Al})_{4} \mathrm{O}_{10}(\mathrm{OH})_{2} \\
0,33 \mathrm{M}^{+}\left(\mathrm{Al}_{1,67} \mathrm{Mg}_{0,33}\right)_{1} \mathrm{Si}_{4} \mathrm{O}_{10}(\mathrm{OH})_{2} \\
0,33 \mathrm{M}^{+} \mathrm{Mg}_{3}\left(\mathrm{Si}_{3,67} \mathrm{Al}_{0,33}\right) \mathrm{O}_{10}(\mathrm{OH})_{2} \\
0,33 \mathrm{M}^{+}(\mathrm{Mg}, \mathrm{Zn})_{3}\left(\mathrm{Si}_{3,67} \mathrm{Al}_{0,33}\right) \mathrm{O}_{10}(\mathrm{OH})_{2} \\
0,33 \mathrm{M}^{+}(\mathrm{Mg}, \mathrm{Li})_{3}\left(\mathrm{Si}_{3,67} \mathrm{Al}_{0,33}\right) \mathrm{O}_{10}(\mathrm{OH})_{2}\end{array}$ \\
\hline $\begin{array}{l}\text { Silicatos } \\
\text { em camadas ou } \\
\text { lamelares } 2: 1\end{array}$ & Vermiculita & $\begin{array}{l}\text { Vermiculita dioctaédrica } \\
\text { Vermiculita }\end{array}$ & $\begin{array}{l}0,67 \mathrm{M}^{+}(\mathrm{Al}, \mathrm{Fe}, \text { etc })(\mathrm{Si}, \mathrm{Al})_{4} \mathrm{O}_{10}(\mathrm{OH})_{2} \\
0,67 \mathrm{M}^{+}(\mathrm{Al}, \mathrm{Fe}, \text { etc })(\mathrm{Si}, \mathrm{Al})_{4} \mathrm{O}_{10}(\mathrm{OH})_{2}\end{array}$ \\
\hline $\begin{array}{l}\text { Silicatos } \\
\text { em camadas } \\
\text { ou } \\
\text { lamelares } \\
2: 1\end{array}$ & \begin{tabular}{|l|} 
Micas \\
hidratadas \\
hidromicas
\end{tabular} & $\begin{array}{l}\text { Moscovita - ilita } \\
\text { Glauconita } \\
\text { Paragonita } \\
\text { Celadonita } \\
\text { Flogopita } \\
\text { Biotita - lediquita } \\
\text { Lepidomelana }\end{array}$ & 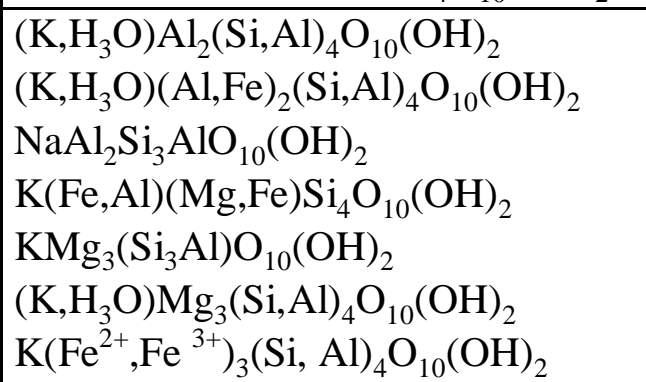 \\
\hline $\begin{array}{l}\text { Silicatos } \\
\text { em cadeia ou } \\
\text { fibrosos. } 2: 1\end{array}$ & Paligorsquita & $\begin{array}{l}\text { Pirofilita } \\
\text { Talco } \\
\text { Paligorsquita }\end{array}$ & $\begin{array}{l}\mathrm{Al}_{2} \mathrm{Si}_{4} \mathrm{O}_{10}(\mathrm{OH})_{2} \\
\mathrm{Mg}_{3} \mathrm{Si}_{4} \mathrm{O}_{10}(\mathrm{OH})_{2} \\
\left(\mathrm{Mg}_{2,5-\mathrm{x}} \mathrm{Al}_{\mathrm{x}}\right)\left(\mathrm{Si}_{4-\mathrm{x}} \mathrm{Al}_{\mathrm{X}}\right) \mathrm{O}_{10}(\mathrm{OH})\left(\mathrm{OH}_{2}\right)_{2}\end{array}$ \\
\hline $\begin{array}{l}\text { Silicatos } \\
\text { em cadeia ou } \\
\text { fibrosos. } 2: 1\end{array}$ & Sepiolita & Sepiolita & $\left(\mathrm{Mg}_{4-\mathrm{x}} \mathrm{Al}_{\mathrm{x}}\right)\left(\mathrm{Si}_{6-\mathrm{x}} \mathrm{Al}_{\mathrm{x}}\right) \mathrm{O}_{15}(\mathrm{OH})_{2}\left(\mathrm{OH}_{2}\right)_{2}$ \\
\hline
\end{tabular}

Fonte: (Souza Santos, 1975) 
Nota: $\mathrm{O}$ símbolo $\mathrm{M}^{+}$é um cátion monovalente que fica entre as camadas basais para neutralizar o desbalanceamento de cargas na estrutura cristalina proveniente das substituições nas camadas octaédricas. O termo Bentonita não aparece na tabela, porém, na realidade é montmorilonita da localidade de Fort Benton, em Wyoming, Estados Unidos, a que deu origem a esse nome.

Tabela 3 - Argilominerais 2:1 [antigamente 2:2] (tetramórficos); com camada de hidróxidos intercalada, clóricos ferro - alumino - magnesiano, segundo Warshaw e Roy (1967).

\begin{tabular}{|c|c|c|c|c|c|c|}
\hline \multirow[t]{2}{*}{ Fórmula Idealizada } & & & & \multicolumn{3}{|c|}{ Cloritas Normais } \\
\hline & $\begin{array}{l}\mathrm{R}^{2+}=\mathrm{Mg} \\
\mathrm{R}^{3+}=\mathrm{Al}\end{array}$ & $\begin{array}{l}\mathrm{R}^{2+}=\mathrm{Fe}^{2+} \\
\mathrm{R}^{3+}=\mathrm{Fe}^{3+}, \mathrm{Al}\end{array}$ & & & & \\
\hline $\mathrm{R}_{6}^{2+} \mathrm{Si}_{4} \mathrm{O}_{10}(\mathrm{OH})_{8}$ & $\begin{array}{l}\text { Crisotila } \\
\text { Antigorita } \\
\text { Lizardita }\end{array}$ & Greenalita & Peninita & $\begin{array}{l}\text { (ortoc } \\
\text { Diab }\end{array}$ & $\begin{array}{l}\text { loritas) } \\
\text { antita }\end{array}$ & $\begin{array}{l}\text { (leptoclorita) } \\
\text { Delessita }\end{array}$ \\
\hline $\mathrm{R}_{5}^{2+} \mathrm{R}^{3+} \mathrm{Si}_{3} \mathrm{R}^{3+} \mathrm{O}_{10}(\mathrm{OH})_{8}$ & flinocloro & Chamosita & $\begin{array}{l}\text { Clinocloro } \\
\text { Sheridanita } \\
\text { Sorindofilita }\end{array}$ & $\begin{array}{l}\text { Pinoclorita } \\
\text { Ripidolita }\end{array}$ & $\begin{array}{l}\text { Dafnita } \\
\text { udoturingita }\end{array}$ & $\begin{array}{l}\text { Chamosita } \\
\text { Turingita }\end{array}$ \\
\hline$R^{2+}{ }_{4}^{3+}{ }_{2}^{3+} \mathrm{Si}_{2} \mathrm{R}_{2}^{3+} \mathrm{O}_{10}(\mathrm{OH})_{8}$ & Amosita & Cronstedtita & & & & \\
\hline
\end{tabular}

Fonte: (Souza Santos, 1975) 
Tabela 4 - Classificação e nomenclatura das cloritas segundo Hey (1954)

\begin{tabular}{|c|c|c|c|c|}
\hline $\begin{array}{l}\text { Espécies } \\
\text { Minerais }\end{array}$ & Fórmula & $\mathrm{Si}$ & $\begin{array}{c}\mathrm{Fe}^{2+} \\
\left(\mathrm{Mg}+\mathrm{Fe}^{2+}\right)\end{array}$ & $\begin{array}{l}\text { Variedades } \\
\text { Químicas }\end{array}$ \\
\hline \multicolumn{5}{|c|}{ Ortocloritas Normais } \\
\hline Corindofilita & $\left(\mathrm{Mg}, \mathrm{Fe}_{2}+, \mathrm{Al}\right)_{6}(\mathrm{Si}, \mathrm{Al})_{4} \mathrm{O} 10(\mathrm{OH})_{8}$ & $2,0-2,5$ & 0,5 & \\
\hline Pseudoturingita & $\left(\mathrm{Fe}^{2+}, \mathrm{Mg}, \mathrm{Al}\right)_{6}(\mathrm{Si}, \mathrm{Al})_{4} \mathrm{O}_{10}(\mathrm{OH})_{8}$ & $2,0-2,5$ & $0,5-1,0$ & \\
\hline Sheridanita & $(\mathrm{Mg}, \mathrm{Al})_{6}(\mathrm{Si}, \mathrm{Al})_{4} \mathrm{O}_{10}(\mathrm{OH})_{8}$ & $2,5-2,8$ & 0,2 & Grochanita (Sheridanita rica em $\mathrm{Fe}^{2+}$ ) \\
\hline Ripidolita & $\left(\mathrm{Mg}, \mathrm{Fe}^{2+}, \mathrm{Al}\right)_{6}(\mathrm{Si}, \mathrm{Al})_{4} \mathrm{O}_{10}(\mathrm{OH})_{8}$ & 2,5 & $0,2-0,8$ & Afrosiderita (Ripidolita rica em $\mathrm{Fe}^{2+}$ ) \\
\hline Dafnita & $\left(\mathrm{Fe}^{2+}, \mathrm{Al}\right)_{6}(\mathrm{Si}, \mathrm{Al})_{4} \mathrm{O}_{10}(\mathrm{OH})_{8}$ & $2,5-2,8$ & $0,8-1,0$ & Bavalita (Dafnita pobre em $\mathrm{Fe}^{2+}$ ) \\
\hline Clinocloro & $\left(\mathrm{Mg}, \mathrm{Fe}^{2+}, \mathrm{Al}\right)_{6}(\mathrm{Si}, \mathrm{Al})_{4} \mathrm{O}_{10}(\mathrm{OH})_{8}$ & $2,8-3,1$ & 0,2 & $\begin{array}{l}\text { Leuchtenbergita (Clinocloro rico em } \\
\mathrm{Fe}^{2+} \text { ) }\end{array}$ \\
\hline Pinoclorita & $\left(\mathrm{Mg}, \mathrm{Fe}^{2+}, \mathrm{Al}\right)_{6}(\mathrm{Si}, \mathrm{Al})_{4} \mathrm{O}_{10}(\mathrm{OH})_{8}$ & $2,8-3,1$ & $0,2-0,5$ & $\begin{array}{l}\text { Kochubeita (Clinocloro com mais de } \\
4 \% \text { de } \mathrm{Cr}_{2} \mathrm{O}_{3} \text { ) }\end{array}$ \\
\hline Brunsvigita & $\left(\mathrm{Fe}^{2+}, \mathrm{Mg}, \mathrm{Al}\right)_{6}(\mathrm{Si}, \mathrm{Al})_{4} \mathrm{O}_{10}(\mathrm{OH})_{8}$ & $2,8-3,1$ & $0,5-0,8$ & Brunsvigita (Peninita com Manganês) \\
\hline Peninita & $\left(\mathrm{Mg}, \mathrm{Fe}_{2+}, \mathrm{Al}_{6}(\mathrm{Si}, \mathrm{Al})_{4} \mathrm{O}_{10}(\mathrm{OH})_{8}\right.$ & $3,1-3,5$ & 0,2 & \\
\hline Diabantita & $\left(\mathrm{Mg}, \mathrm{Fe}^{2+}, \mathrm{Al}_{6}(\mathrm{Si}, \mathrm{Al})_{4} \mathrm{O}_{10}(\mathrm{OH})_{10}\right.$ & 3,1 & $0,2-0,5$ & $\begin{array}{l}\text { Kamerenita (Peninita com mais de } 4 \% \\
\text { de } \mathrm{Cr}_{2} \mathrm{O}_{3} \text { ) }\end{array}$ \\
\hline \multicolumn{3}{|c|}{ Ortocloritas oxidadas $\left(\mathrm{Fe}_{2} \mathrm{O} 3\right)$ acima de $4 \%$. } & $\mathrm{Fe}^{3+}+\mathrm{OH}=$ & \\
\hline Turingita & $\left(\mathrm{Fe}^{3+}, \mathrm{Fe}^{2+}, \mathrm{Mg}, \mathrm{Al}\right)_{6}\left(\mathrm{Si}, \mathrm{Al}_{4} \mathrm{O}_{10}(\mathrm{OH})_{8}\right.$ & $2,0-2,8$ & 8 & $\begin{array}{l}\text { Klementita(Turingita com } \mathrm{Mg} \text { superior } \\
\left.\text { a } \mathrm{Fe}^{2+}, \mathrm{Fe}^{3+}\right)\end{array}$ \\
\hline Chamosita & $\left(\mathrm{Fe}^{2+}, \mathrm{Fe}^{3+}, \mathrm{MgAl}\right)_{6}(\mathrm{Si}, \mathrm{Al})_{4} \mathrm{O}_{10}(\mathrm{OH})_{8}$ & $2,8-3,1$ & 8 & $\begin{array}{llll}\begin{array}{l}\text { Penentita (Klementita } \\
\text { substituído por } \mathrm{Mn} \text { ) }\end{array} & \text { com } & \mathrm{Mg} \\
\end{array}$ \\
\hline Delessita & $\left(\mathrm{Mg}_{3} \mathrm{Fe}^{2+}, \mathrm{Fe}^{3+}, \mathrm{Al}_{6}\left(\mathrm{SI}_{3}, \mathrm{Al}_{4} \mathrm{O}_{10}(\mathrm{OH})_{8}\right.\right.$ & 3,1 & 8 & \\
\hline
\end{tabular}

Fonte: (Souza Santos, 1975)

Tabela 5 - Esquema de classificação para os filossilicatos relacionados com os argilominerais (Bailey et al., 1971)

\begin{tabular}{|c|c|c|c|}
\hline Tipo & $\begin{array}{c}\text { Grupo } \\
(x=\text { carga por unidades de fórmula })\end{array}$ & Subgrupo & Espécies* \\
\hline $1: 1$ & $\begin{array}{c}\text { Caulinita - Serpentina } \\
(x=0) \\
\text { Pirofilita - Talco } \\
(x=0) \\
\text { Esmectita ou montmorilonitas - } \\
\text { - saponita } \\
(x=0,25 \text { a } 0,60)\end{array}$ & $\begin{array}{l}\text { Caulinitas } \\
\text { Serpentinas } \\
\text { Pirofilitas } \\
\text { Talco } \\
\text { Esmectitas dioctaédricas ou } \\
\text { montmorilonitas } \\
\text { Esmectitas trioctaédricas ou } \\
\text { saponitas }\end{array}$ & $\begin{array}{l}\text { Caulinita, haloisita } \\
\text { Crisotila, lizardita, antigorita } \\
\text { Pirofilita } \\
\text { Talco } \\
\text { Montmorilonita, beidelita, } \\
\text { nontronita } \\
\text { Saponita, hectorita, sauconita }\end{array}$ \\
\hline $2: 1$ & $\begin{array}{c}\text { Vermiculita } \\
(x=0,60 \text { a } 0,90) \\
\text { Mica** } \\
(x=1) \\
\text { Mica quebradiça } \\
(x=2)\end{array}$ & $\begin{array}{l}\text { Vermiculitas dioctaédricas } \\
\text { Vermiculitas trioctaédricas } \\
\text { Micas dioctaédricas } \\
\text { Micas trioctaédricas } \\
\text { Mica quebradiça dioctaédrica } \\
\text { Mica quebradiça trioctaédrica }\end{array}$ & $\begin{array}{l}\text { Vermiculita dioctaédrica } \\
\text { Vermiculita trioctaédrica } \\
\text { Moscovita, paragonita } \\
\text { Biotita, flogopita } \\
\text { Margarita } \\
\text { Clintonita }\end{array}$ \\
\hline $2: 1: 1$ & $\begin{array}{c}\text { Clorita } \\
\text { (x variável) }\end{array}$ & $\begin{array}{l}\text { Cloritas dioctaédricas } \\
\text { Cloritas ditrioctaédricas } \\
\text { Cloritas trioctaédricas }\end{array}$ & \begin{tabular}{|l|} 
Donbassita \\
Cookeíta, sudoíta \\
Peninita, clinocloro, proclorita
\end{tabular} \\
\hline
\end{tabular}

Fonte: Souza Santos, P. Tecnologia das Argilas (1992). 
São apresentados apenas alguns exemplos das espécies de argilominerais nesta tabela. Os nomes ilita para micas hidratadas ou hidromicas e sericita devem ser deixados em aberto, no momento, porque ainda não está claro em que nível devem entrar nesta tabela; além disso, muitos materiais que receberam esses nomes podem ser interestratificados.

Tabela 6 - Classificação dos Argilo - minerais.

\begin{tabular}{|c|c|c|}
\hline \multirow{2}{*}{$\begin{array}{l}\text { I. } \\
\text { Amorfos }\end{array}$} & \multicolumn{2}{|l|}{ Grupo Alofana } \\
\hline & $\begin{array}{l}\text { A. Tipo duas camadas (uma tetraedros } \\
\text { de } \mathrm{SiO}_{4} \text { e a outra octaedros de } \mathrm{Al}_{2} \mathrm{O}_{3} \text { ): }\end{array}$ & $\begin{array}{l}\text { 1. Equidimensonais } \\
\text { Grupo da Caulinita: } \\
\text { Caulinita, Nacrita } \\
\text { 2. Alongado } \\
\text { Grupo Haloisita } \\
\end{array}$ \\
\hline $\begin{array}{l}\text { II. } \\
\text { Cristalinos }\end{array}$ & $\begin{array}{l}\text { B. Tipo três camadas: (duas camadas de } \\
\mathrm{SiO}_{4} \text { e uma central dioctaédrica ou } \\
\text { trioctaédrica) }\end{array}$ & $\begin{array}{l}\text { 1. Rede em expansão } \\
\text { a) Equidimensional } \\
\text { Grupo da Montmorilonita: } \\
\text { Montmorilonita, vermiculita, } \\
\text { etc. } \\
\text { b) Alongado } \\
\text { Grupo Montmorilonita: } \\
\text { Nontronita, saponita, hectorita } \\
\text { 2. Rede não em expansão } \\
\text { Grupo da Ilita }\end{array}$ \\
\hline & C. Tipo de Camadas Misturadas & Grupo das Cloritas \\
\hline & D. Tipo de estrutura em cadeia. & $\begin{array}{l}\text { Atapulgita, } \\
\text { Paligorsquita }\end{array}$ \\
\hline
\end{tabular}

(Adaptado de Grimm, 1953, 1968)

\subsection{3 - Propriedades físicas das argilas}

As principais propriedades físicas gerais dos argilominerais são:

- Plasticidade

- Dureza baixa, aproximadamente 2-2,5

- Peso específico, aproximadamente 2-2,7

- Viscosidade

- Impermeabilidade 
Além destas propriedades físicas, os argilominerais apresentam outras propriedades chamadas de tecnológicas que também definem ou determinam suas utilizações industriais, como podem ser:

- Granulometria muito fina, da ordem dos micrômetros.

- Características óticas como cor, brilho, reflexão da luz, opacidade.

- Capacidade de troca de íons

- Expansividade

- Absorção de água

- Refratariedade

e mais outras. As que definem ou influem no sistema de desmonte e escavação durante a lavra são as do primeiro grupo acima exposto

2.2.4 -Alguns comentários sobre a água nas Argilas, sua natureza, seu papel

A água, nas argilas, está em estreita relação com sua estrutura; por isto tem papel preponderante, e permite caracterizar os diversos tipos de argilas [Prentice, 1990, Rodrigues, 1978].

Há diversos tipos de águas ou diversas maneiras das argilas reterem águas, temos assim:

r A água de constituição. Assim chamada porque faz parte integral da estrutura cristalina. Ela está representada pelos grupos de oxidrilas $\mathrm{OH}$ existentes, que por aquecimento acima de $300 \mathrm{C}^{\circ}$ (geralmente entre $500 \stackrel{\circ}{\mathrm{C}}$ e $700 \mathrm{C}^{\circ}$ ), são expulsos do arcabouço cristalino sob a forma de água. Há uma proporcionalidade entre a água de constituição e o resto da massa do argilomineral, tanto assim que a perda dessa água determina a perda da plasticidade da argila, do seu poder descorante, etc.; ou seja, são mudadas as propriedades dos argilominerais.

r A água de adsorção. A adsorção está relacionada à superfície mineral e a tensão de vapor d'água. Segundo Nutting (1943) há varias espécies de água absorvida, a primeira camada d'água em contato com a superfície de cada folheto cristalino de silicato retido por forças comparáveis as das valências químicas e as outras camadas d'água que seguem a esta. 
As primeiras só podem ser removidas por aquecimento a temperaturas que atingem a água de constituição, as camadas externas variam com a umidade, não afetando a estrutura cristalina das argilas com sua entrada ou saída.

- A água de adsorção é apreciável e tem papel preponderante, principalmente nas argilas do grupo das montmorilonitas; a adsorção se dá entre as unidades tríplices que constituem o cristal e provoca o aumento de espaçamento entre elas, na direção de altura, isto é, em relação aos eixos a e b, não são alteradas; por isto, esta água é chamada também de água de entre - camadas.

- A água e a plasticidade das argilas: Admite-se que a argila se torna plástica devido ao filme d'água que envolve as suas partículas; esse filme permite às partículas deslizar umas sobre outras, e a argila pode, em conseqüência, ser moldada, sem que haja rompimento da coesão. O grau de plasticidade de uma argila depende das características do filme d'água, que são: orientação, densidade e espessura.

- Deve-se então, compreender porque a água influi no aspecto externo das argilas (cor, volume, etc.) e nas propriedades físicas e tecnológicas delas.

\subsection{5 - Argilas Bentoníticas do Estado da Paraíba}

As argilas bentoníticas de Boa Vista (PB) formam pequenos depósitos distribuídos numa distância de $10 \mathrm{Km}$. As rochas encaixantes são o derrame basáltico no lado leste e os granitos e gnaisses do Pré-Cambriano a oeste. A argila bentonita é caracterizada pela predominância dos argilo-minerais esmectita, ilita e caulinita. A argila em alguns depósitos ocorre intercalada com basalto alterado em outros com areia, silte e calcedônica bem como ocorre, em várias tonalidades de cores. As principais tonalidades das cores observadas são: chocolate, verde, bofe, vermelho e branco, embora nas jazidas classificam-se em cores de combinação dessas principais cores mencionadas acima. As propriedades tecnológicas das argilas demonstram uma certa dependência às cores existentes [Valenzuela-Díaz, 1992].

Em 2001, a quantidade de bentonita bruta e beneficiada produzida no Estado da Paraíba representou 96\% do total da produção brasileira, sendo a parcela restante (4\%) produzida no Estado de São Paulo. No segmento de processamento, além do beneficiamento simples de desintegração, 
homogeneização e secagem, é realizada a troca catiônica, pela adição do carbonato de sódio (barrilha) transformando a bentonita, naturalmente cálcica, em sódica. No Brasil foram produzidas, em 2001197.100 t de bentonitas brutas das quais $160.000 \mathrm{t}$ foram beneficiadas. $O$ preço médio da bentonita bruta foi de $\mathrm{R} \$ 9,00 / \mathrm{t}$ e de beneficiada de $\mathrm{R} \$ 100,00 / \mathrm{t}$. Em 2001 o Brasil importou 74.279 t de bentonitas, com um preço médio de US $\$ 123 / t$ (FOB). O consumo aparente brasileiro de bentonitas beneficiadas em 2001 foi de 360.056 t, o que corresponde, aproximadamente, a um consumo aparente per capita, de 1,9 Kg [Trindade, 2001].

Os Estados Unidos da América produziram em 2001 perto de 4.000.000 toneladas de bentonitas, o que corresponde, aproximadamente, a uma produção per capita de $15 \mathrm{Kg}$. [Trindade, 2001].

\subsubsection{Terras Fuller}

Terra Fuller é a denominação geral das argilas que possuem na sua forma natural um alto poder descorante, são constituídas por partículas de pequenas dimensões, com alta capacidade de adsorção, constituída principalmente de silicatos de alumínio hidratados, esmectítas e/ou paligorsquitas sepiolitas. As Terras Fuller são utilizadas no descoramento de óleos vegetais, animais e minerais. Na regeneração do fluido isolante de transformadores elétricos e em outros usos similares.

\section{3 - NANOCOMPÓSITOS}

A necessidade de materiais modernos, isto é, com características diferenciadas, está cada vez maior tornou a pesquisa por novos materiais muito grande.

Um compósito pode ser definido como um material formado por dois, ou mais constituintes diferentes, que oferece propriedades que não são possíveis de se obter a partir dos seus componentes individuais. Um nanocompósito, por outro lado, constitui uma nova fase de materiais bifásicos, onde uma das fases possui dimensões em escala nanométrica. Desta maneira, as propriedades destes materiais não são resultantes da soma das 
propriedades individuais dos componentes de cada fase. Um bom exemplo de um nanocompósito é um vidro dopado com pequenas partículas metálicas, que é um material colorido e altamente transparente, exibindo uma única banda de absorção no visível. Uma vez que pela própria definição de nanocompósitos as dimensões e o espaçamento entre os grãos da nanofase devem ser muito menores que o comprimento de onda da luz visível, pode-se obter materiais opticamente transparentes, como o exemplo citado anteriormente, com propriedades que seriam inimagináveis de se obter em outros materiais.

Um compósito (ou nanocompósito) pode ser formado entre duas fases orgânicas, duas fases inorgânicas ou entre uma fase orgânica e outra inorgânica. A possibilidade de se combinar propriedades de compostos orgânicos e inorgânicos em um único material é um desafio antigo. O conceito de materiais híbridos orgânico/inorgânicos emergiu recentemente, com pesquisas em materiais mais sofisticados, com altos valores agregados. $O$ estudo de nanocompósitos orgânico/inorgânicos expandiu este campo de investigação.

Geralmente, os materiais orgânicos são "frágeis", e sua estabilidade térmica está limitada a $250^{\circ} \mathrm{C}$. Isto faz com que seja impossível a obtenção de qualquer tipo de material híbrido através de processos que envolvam altas temperaturas. Contudo, dois processos tornaram-se importantes para reverter este quadro: i) o processo sol-gel, que produz materiais inorgânicos à temperatura ambiente a partir de soluções de precursores metalo-orgânicos; ii) a polimerização in situ no interior de espaços vazios de materiais inorgânicos hospedeiros.

A síntese e estudo das propriedades de novos nanocompósitos é uma área recente e emergente, com perspectivas fascinantes no campo das ciências dos materiais [www.quimico.ufpr.br].

\section{4 - AMIDO}

O amido, também conhecido como amilo, é um POLISSACARÍDEO com cerca de 1.400 meros de glicose. Funciona como substância de reserva para muitas plantas, entre as quais a mais conhecida é a batata.O Amido é 
formado pela condensação de moléculas de glicose, que são liberadas quando o amido é hidrolisado.

\subsection{1 - Formação do Amido}<smiles>OCC1OC(O)C(O)C(O)C1O</smiles>

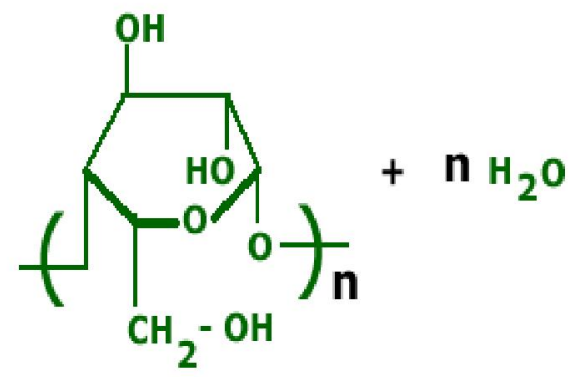

Figura 5 - formação do amido.

A figura 5 mostra a reação de formação do amido.

\subsection{2 - Estrutura molecular do amido}

O grão de amido é uma mistura de dois polissacarídeos: amilose e amilopectina. A figura 6 apresenta a fórmula estrutural da (a) amilose e (b) amilopectina.

$\checkmark \quad$ Amilose

Polissacarídeo linear. Macromolécula constituída de 250 a 300 meros de D-glicopiranose, ligados por pontes glicosídicas alfa -1,4, que conferem a molécula uma estrutura helicoidal, assim suas moléculas são muito diferentes da celulose.

\section{$\diamond \quad$ Amilopectina}

Macromolécula menos hidrossolúvel que a amilose, sendo que suas moléculas são semelhantes mas no caso da amilopectina, apresentam ramificações e são constituídas de aproximadamente 1400 resíduos de a-glicose ligadas por pontes glicosidicas alfa -1,4, ocorrendo também ligações alfa -1,6. A amilopectina constitui, aproximadamente, $80 \%$ dos polissacarídeos existentes no grão de amido. 

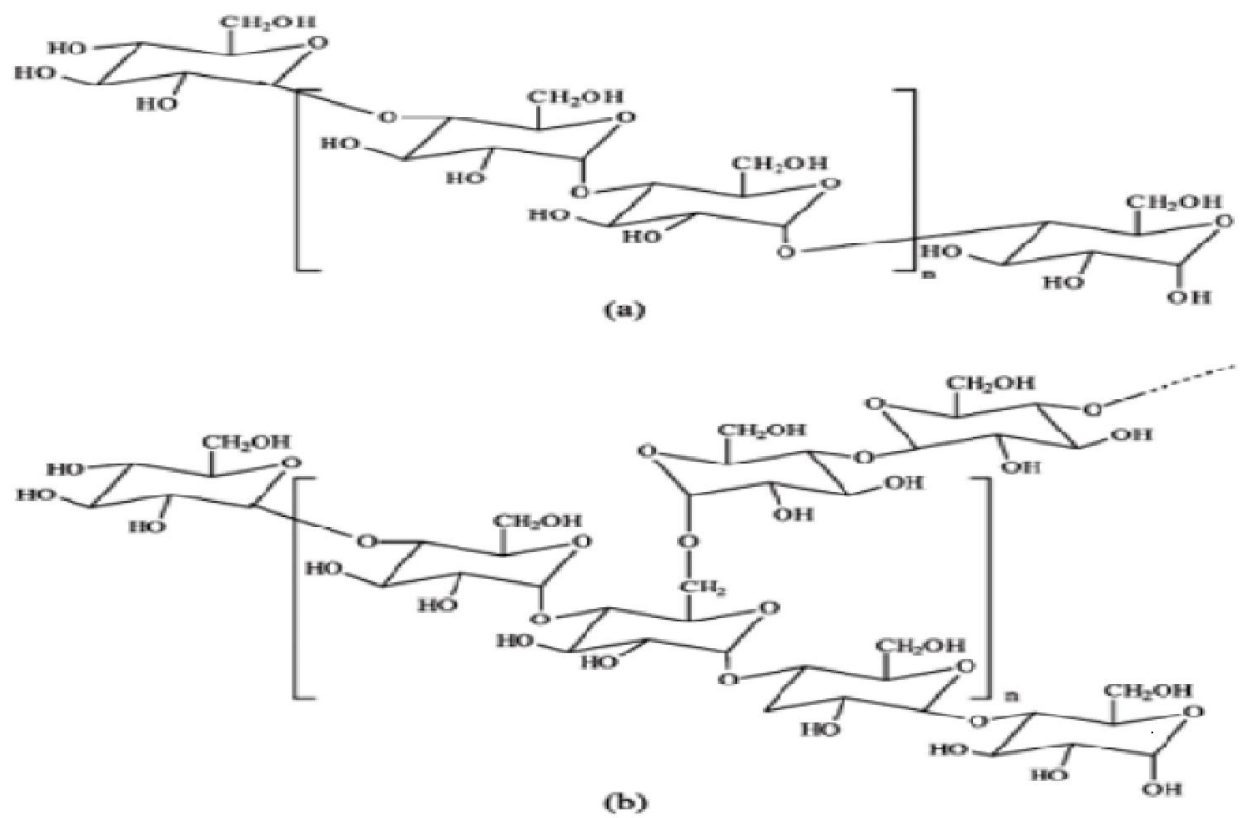

Figura 6 - estrutura do amido. a) amilose, b) amilopectina

\subsection{3 - Nomenclatura - Amido / Fécula}

$\checkmark \quad$ Amido é o produto amiláceo extraído das partes aéreas comestíveis dos vegetais (sementes, etc).

$\checkmark$ Fécula é o produto amiláceo extraído das partes subterrâneas dos vegetais (tubérculos, raízes e rizomas).

O produto é designado "amido" ou "fécula", seguido do nome do vegetal de origem. Exemplo: amido de milho, fécula de batata. 


\subsection{4 -Usos industriais do amido}

O amido tem sido muito utilizado em pesquisas para a produção de novos materiais biodegradáveis para possíveis aplicações substituindo os polímeros derivados do petróleo.

Atualmente, há um grande número de pesquisas relacionadas à utilização do amido, pois além dele ser de origem vegetal, é um polímero natural, abundante, barato e renovável e apresenta caráter biodegradável.

\subsubsection{1 - Amido termoplástico}

O amido, sob pressão e temperatura e na presença de um agente plastificante, pode ser gelatinizado, e sob efeito de cisalhamento se transformar em um fundido. Uma grande vantagem da utilização do amido termoplástico é que ele é compostável e pode ser processado nos mesmos equipamentos, tradicionalmente empregados para 0 processamento de plásticos convencionais.

$O$ amido tem sido utilizado em sacos de lixo, filmes para proteger alimentos, fraldas infantis, hastes flexíveis com pontas de algodão para uso na higiene pessoal; na agricultura vem sendo empregado como filme na cobertura do solo e recipientes para plantas. Também pode ser usado na preparação de cápsulas, em substituição do poliestireno expandido (isopor) na proteção de equipamentos durante o transporte; na produção de talheres, pratos e copos descartáveis, na fabricação de canetas, lapiseiras, brinquedos e outras aplicações onde o caráter biodegradável seja requerido [Dean, 2007; Kampeerapappum, 2007; Ray, 2005].

\subsubsection{2 - Preparação de compósitos a base de amido}

Li (2005) obteve um compósito superabsorvente a base de amido de batata. A caracterização foi feita por medidas de absorbância, espectroscopia-infra vermelho e termogravimetria. 


\subsubsection{3 - Preparação de espumas a base de amido- fécula de mandioca}

Carr (2007) obteve uma embalagem tipo espuma utilizando a fécula de mandioca como principal componente. A espuma foi obtida pelo processo de termoexpansão, onde uma massa de amido, água e aditivos é colocada dentro de um molde fechado aquecido. $\mathrm{O}$ vapor liberado pela massa expande a massa, que preenche o molde. Com a total saída da água, os componentes sólidos formam uma estrutura porosa, a espuma.

\subsubsection{Preparação de filmes biodegradáveis a base de amido}

Larotonda (2004) obteve filmes biodegradáveis a partir do amido da mandioca. Para isto trabalhou com duas rotas. $\mathrm{Na}$ primeira termoprocessamento - utilizou o amido gelatinizado e o glicerol como plastificante. Na segunda, o amido foi solubilizado com solventes orgânicos.

Corradini (2005) obteve amido termoplástico a partir do amido com diferentes teores de amilose, por processamento em um misturador intensivo e glicerol como plastificante. A caracterização foi feita por medidas de absorção de água, difração de raios $X$ (DRX), ensaios mecânicos de tração e análises dinâmico mecânicas (DMA). A conclusão deste trabalho foi de que é possível empregar o amido para a fabricação de utensílios biodegradáveis de baixa solicitação mecânica e curto tempo de uso. Entretanto, para uma melhoria nas suas propriedades mecânicas é aconselhado o uso de outro material como reforço.

\subsubsection{5 - Preparação de filmes e polímeros amido/bentonita}

Wilhelm (2003) estudou os filmes reforçados por argila. Utilizou o amido de cará e o glicerol (plastificante). A caracterização foi feita por difração de raios $X$ (DRX), microscopia eletrônica de varredura (MEV), termogravimetria, espectroscopia de infravermelho. Os resultados demonstraram que a adição da argila (30\% em peso) resultou em aumentou de mais que $70 \%$ no módulo de Young.

Avella (2005) obteve filmes biodegradáveis por dispersão homogênea de nanopartículas de montmonrilonita e diferentes amidos. As amostras foram caracterizadas mecânica e estruturalmente. Notou que os parâmetros 
mecânicos como resistência à tensão e modular foram melhorados quando a argila foi adicionada.

Chen (2005) comparou nanocompósitos de amido/glicerol termoplástico e diferentes argilas - montmorilonita, hectorita e caulinita. A caracterização foi feita por difração de raios X (DRX), microscopia eletrônica de transmissão (MET), e foram medidos os módulos de Young e de cisalhamento. Chiou (2005) incorporou diferentes amostras de amido - trigo, milho, milho e batata - em montmorilonita. Utilizou também as argilas sódicas Cloisite $\mathrm{Na}+$ ? hidrofílica e Cloisite 30B, 10 A e 15 A hifrofóbicas. A caracterização das amostras foram executadas por ensaios reologicos e por DRX.

Chen (2005) preparou espumas à base de nanocompósitos de amido termoplásticos (TPS) e argila montomorilonita. O plastificante utilizado foi uréia, sendo que houve melhora tanto na dispersão da argila tratada com amônio quanto das propriedades necessárias para a armazenagem do produto. A caracterização foi feita por DRX, MEV e termogravimetria. Segundo o autor a desvantagem é a quantidade de amônio presente no produto, que está numa faixa não recomendável.

Piyporn (2006) preparou um compósito a base de montmorilonita amido de mandioca e glicerol (plastificante) além de um polímero natural (chitosan). Os resultados das análises dos produtos indicam que a adição do chitosan, bem como da argila, melhorou algumas propriedades do compósito de amido. $O$ chitosan reforça a tensão e o módulo de Young, enquanto a argila reforça suas propriedades mecânicas. A caracterização foi feita por DRX e MEV. Foram medidas as propriedades de tensão, transparência, absorção e velocidade de transmissão de vapor d'água (VWTR).

\subsection{ADSORÇÃO}

O fenômeno da adsorção é conhecido desde o século XVIII, quando se observou que certa espécie de carvão retinha em seus poros grandes quantidades de vapor d’água, o qual era liberado quando submetido ao aquecimento [Rodrigues, 2004, Chaari, 2007]. 
O termo adsorção parece ter sido usado pela primeira vez por Kayser, em 1881, para denotar a condensação de gases em superfícies, ao contrário do termo absorção, em que o gás penetra dentro da massa do sólido absorvente. Hoje, adsorção é um termo convencionado internacionalmente como correspondendo ao enriquecimento de uma camada sólida (interfacial) por um ou mais elementos, sendo que essa "captura" pode ser feita por dois mecanismos: adsorção química ou adsorção física [Albanez, 1996].

Nas últimas décadas, com o avanço das pesquisas e do conhecimento na área, bem como o acentuado desenvolvimento registrado na petroquímica, a adsorção passou a ser utilizada como uma operação unitária importante dentro da engenharia química.

Atualmente, a adsorção é aplicada em processo de purificação e separação, apresentando-se como uma alternativa importante e economicamente viável em muitos casos.

Exemplos mais comuns de tais processos são os chamados processos de purificação, onde se utiliza geralmente uma coluna de leito fixo empacotada com adsorvente para remover umidade de uma corrente gasosa, ou ainda remover impurezas de uma corrente líquida, como por exemplo, de um efluente industrial. Quando os componentes a serem adsorvidos estão presentes em baixas concentrações e possuem baixo valor agregado geralmente não são recuperados.

A separação de misturas em duas ou mais correntes, enriquecidas com espécies as quais deseja-se recuperar é uma aplicação mais recente dos processos adsortivos e que vem desenvolvendo-se muito nos últimos anos devido à capacidade destes processos realizarem separações importantes em situações onde a destilação convencional se revela ineficiente ou onerosa.

Adsorção é a adesão de moléculas de um fluido (o adsorvido) a uma superfície sólida (o adsorvente); o grau de adsorção depende da temperatura, da pressão e da área da superfície - os sólidos porosos como o carvão são ótimos adsorventes.

Classificam-se os fenômenos adsortivos quanto às forças responsáveis, em dois tipos: adsorção química - ou quimissorção - e adsorção física - ou fisissorção.

A adsorção química, também chamada de quimissorção, é específica e é empregada na separação de misturas. Nela as moléculas (ou átomos) unem-se à superfície do adsorvente através da formação de ligações químicas (geralmente 
covalentes) e tendem a se acomodarem em sítios que propiciem o maior número de coordenação possível com o substrato. Uma molécula quimicamente adsorvida pode ser decomposta em virtude de forças de valência dos átomos da superfície e é a existência de fragmentos moleculares adsorvidos que responde, em parte, pelo efeito catalítico das superfícies sólidas.

A adsorção física, também chamada de fisissorção, é empregada em máscaras contra gases e na purificação e descoloração de líquidos. Nela as moléculas do adsorvente e do adsorvato interagem por interações de van der Waals, que apesar de serem interações de longo alcance, são fracas e não formam ligações químicas. Uma molécula fisicamente adsorvida retém sua identidade, embora possa ser deformada pela presença dos campos de força da superfície.

Sabe-se que apesar destes dois mecanismos apresentarem naturezas distintas, eles não são facilmente distinguíveis experimentalmente e, comumente, descrevem-se ambos os processos por modelos de adsorção física; mas um modelo que dê conta de ambos separadamente também não foi proposto até hoje, sabendo-se apenas que há uma diferença entre os tempos de adsorção para cada processo [www. deq.ufpe.br]..

Sendo a adsorção um fenômeno essencialmente de superfície, para que um adsorvente tenha uma capacidade adsortiva significante, deve apresentar uma grande área superficial específica, o que implica em uma estrutura altamente porosa. As propriedades adsortivas dependem do tamanho dos poros, da distribuição do tamanho dos poros e da natureza da superfície sólida. Os adsorventes mais utilizados em escala industrial atualmente são o carvão ativado, a sílica-gel, a alumina ativada e as peneiras moleculares.

Os chamados adsorvente amorfos - carvão ativado, sílica-gel e alumina apresentam áreas específicas entre $200-1000 \mathrm{~m}^{2} / \mathrm{g}$, e uma faixa de distribuição de tamanho de poros bem ampla, enquanto que as peneiras moleculares, por serem materiais cristalinos apresentam um tamanho de poro de ordem de grandeza molecular definido pela estrutura cristalina, e que praticamente não varia. Quanto ao tamanho dos poros, estes podem classificar-se em três categorias, conforme sugere a IUPAC (International Union of Pure and Applied Chemistry) [www. deq.ufpe.br]: 


\begin{tabular}{cc} 
& Diâmetro \\
\hline Microporos & $<2 \mathrm{~nm}$ \\
\hline Mesoporos & $2-50 \mathrm{~nm}$ \\
\hline Macroporos & $>50 \mathrm{~nm}$ \\
\hline
\end{tabular}

A sílica-gel é formada quando um silicato solúvel é neutralizado por ácido sulfúrico, retirando-se a água, um sólido poroso é obtido. Sua composição química pode ser expressa como $\mathrm{SiO}_{2} \cdot \mathrm{nH}_{2} \mathrm{O}$. Sua principal aplicação industrial como adsorvente é a retirada de umidade de correntes gasosa, mas também foi utilizada na separação de compostos aromáticos de parafínicos e naftênicos no processo Arosorb [www. deq.ufpe.br].

A alumina ativada é constituída de óxido de alumínio e é comumente obtida da bauxita. Sua aplicação industrial mais importante também é na desidratação de correntes gasosas e em algumas purificações específicas de correntes líquidas [www. deq.ufpe.br].

O carvão ativado é um dos primeiros adsorventes conhecidos e um dos mais utilizados atualmente. Pode ser produzido de várias maneiras e suas características vão depender da matéria-prima utilizada e da forma de ativação. Geralmente é produzido pela decomposição térmica de material carbonáceo seguido pela ativação com vapor ou dióxido de carbono em temperaturas elevadas. Sua superfície possui afinidade com substâncias de caráter orgânico, conferindo-Ihe sua principal aplicação atualmente, a descontaminação de água destinada ao consumo humano. Utilizando-se técnicas modernas de ativação é possível produzir um novo material chamado peneira molecular de carvão - um carvão ativado com estreita distribuição de poros, na faixa observada nas peneiras moleculares. Uma utilização em larga escala destas peneiras moleculares de carvão é na separação de gases [www. deq.ufpe.br].

\subsubsection{Determinação da área superficial específica}

A adsorção sobre sólidos é um fenômeno de grande importância em química, mais especificamente em físico-química. Quando se expõe um sólido 
finamente dividido a uma pressão moderada de um gás, geralmente a pressão do gás decresce, indicando que parte das moléculas do gás foram adsorvidas na superfície do sólido. Pelo mesmo motivo observa-se que expondo uma solução de um corante (ou de uma tinta) ao sólido, a intensidade da coloração da solução decresce acentuadamente. Deve ser salientado também que a ação catalítica de muitas substâncias, no caso da catálise heterogênea, está ligada a estes fenômenos da adsorção [Albanez, 1996].

A intensidade desses efeitos depende da temperatura, da natureza das substâncias presentes no meio, da pressão do gás, ou da concentração do corante. Um fato bastante importante está relacionado com a superfície do sólido. Quanto mais finamente dividido estiver este sólido, maior será a sua eficiência em adsorver as moléculas presentes no meio.

Experimentalmente, as medidas nesses sistemas são feitas em termos de quantidade de substância adsorvida por grama do sólido, com a finalidade de se obter as chamadas isotermas de adsorção. Essas isotermas são gráficos onde estão representados $\mathrm{N}$, número de moles de substância adsorvida por grama de sólido, versus $C$, concentração de soluto em equilíbrio, ou P, pressão do gás sobre o sólido [Brunauer, 1938].

\section{7 - CARVÃO ATIVADO}

O carvão é um material composto principalmente por carbono, sendo obtido pela remoção de água e outros componentes voláteis, a partir de substâncias animais e vegetais. Geralmente é produzido pelo aquecimento de substâncias que contém carbono, como: madeira, açúcar, casca de coco entre outras, na ausência de oxigênio. É duro, quebradiço, leve, preto e poroso, contendo cerca de $85 \%$ a $98 \%$ de carbono, o restante é constituído por cinzas e produtos voláteis [Neumann, 2000; Patrick, 1995].

Os carvões ativados - ou ativos - estão entre os principais tipos de materiais adsorventes, no entanto eles, freqüentemente, apresentam alto custo e baixa resistência mecânica. A sua capacidade de adsorção está relacionada à sua alta área superficial específica $\left(500 \mathrm{~m}^{2} / \mathrm{g}\right)$ [Neumann, 2000], porosidade e 
à presença de uma variedade de grupos funcionais em sua superfície. Entre as aplicações do carvão estão: remoção de cor - derivada de compostos orgânicos - de águas de esgoto, principalmente de indústrias têxteis [Guilarduci, 2006, Namasivayam, 2001, Bandosz,1999]; gosto e odor da água em estações de tratamento de água (ETAs) [Guilarduci, 2006]; na purificação de gases, remoção de gases poluentes, como o ácido sulfídrico $\left(\mathrm{H}_{2} \mathrm{~S}\right)$ e dióxido de enxofre $\left(\mathrm{SO}_{2}\right)$ [Marchetto, 2005] como peneiras moleculares e catalisadores [Brennan, 2001; Schettino, 2007].

A forma do carvão - pó (CAP) ou granulado (CAG) - depende do tipo de aplicação desejada [Guilarduci, 2006]. O maior problema da utilização do carvão ativado é o custo elevado. Assim, atualmente, existem vários grupos de pesquisa trabalhando na obtenção de um produto que tenha as características requeridas, mas de menor preço. Em geral, a proposta destes trabalhos é mudar a matéria-prima, como por exemplo, a utilização do lodo de esgoto proveniente das ETEs ou resíduos orgânicos da agricultura, como, casca de amendoim e de arroz, semente de ameixa, casca de côco, entre outros [Bandosz,1999; Fajula, 2005; Rodrigues, 2006; Schettino, 2007]. A capacidade de adsorção do CA é proveniente da alta ASE e da presença de uma variedade de grupos funcionais em sua superfície. A estrutura do CA é basicamente constituída por uma base grafitítica em que os vértices e as bordas podem acomodar uma série de elementos, como oxigênio, nitrogênio e hidrogênio, que se apresentam como grupos funcionais [Guilarduci, 2006]. Neste trabalho, optou-se pela adição do carvão ativo em pó (CAP) na argila esmectítica, pois ela é considerada vinte vezes mais barata que o carvão ativado. Além disto esta argila apresenta alta capacidade de troca catiônica, elevada área superficial específica e boa estabilidade química e mecânica [Chaari, 2007]. 


\subsubsection{Compósitos Argila/Material Carbonoso}

Carvões ativados estão entre os adsorventes mais eficientes, porém, são materiais de alto custo e apresentam baixa resistência mecânica com altas perdas tanto nos processos de adsorção como nos processos de regeneração. O consumo crescente de floculantes, detergentes, sabões, xampus, materiais oleosos, hidrocarbonetos, etc., aliado a uma maior preocupação pela sociedade quanto ao uso e à preservação da água, assim como restrições cada vez maiores quanto à tolerância de materiais orgânicos tóxicos na água, tem levado vários pesquisadores ao estudo de adsorventes alternativos de baixo custo, como por exemplo: a partir de pneus usados [San Miguel, 2003; Okada, 2003].

Os compósitos silicato material carbonoso e os nanocompósitos silicato material carbonoso são novos tipos de materiais com um alto potencial de uso em adsorção e catálise [Leboda, 1993 e 2000]

Os compósitos silicato material carbonoso podem ser obtidos pelo recobrimento de silicatos, por exemplo por técnicas de CVD, com materiais orgânicos, por exemplo cloreto de metileno, seguidos de pirólise. Os nanocompósitos silicato material carbonoso podem ser obtidos pela intercalação de compostos orgânicos (monômeros ou polímeros) entre as lamelas de filosilicatos, por exemplo argilas, seguida pela polimerização mais pirólise ou pela pirólise direta. As principiais vantagens desses compósitos são uma maior resistência mecânica, aliada à possibilidade de obter-se materiais com diferentes porcentagens de superfície recoberta com material carbonoso (superfície apolar) ou não recoberta (superfície polar) tendo, assim, possibilidades de adsorver diferentes tipos de impurezas polares e apolares [Leboda, 1993, 1998 e 2000]

Também visando a obtenção de adsorventes de baixo custo para o tratamento de água, assim como para a adsorção de gases fétidos, em estações de tratamento de esgotos, diferentes pesquisadores vêm estudando a possibilidade de uso dos lodos, pirolisados, das próprias estações de tratamento de esgotos [Bagreev, 2001].

No LMPSol, Laboratório de Matérias-Primas Particuladas e Sólidos Não Metálicos, do PMT/EPUSP, laboratório no qual foi desenvolvido o presente 
Projeto, têm-se efetuado estudos visando à obtenção e caracterização de compósitos silicato material carbonoso de baixo custo, usando-se diversos substratos, entre eles argilas do tipo taguá [Cosin, 2003].

Também têm sido efetuados estudos visando à obtenção $\mathrm{e}$ caracterização de nanocompósitos de baixo custo argila/material carbonoso [Cosin, 2003].

Os materiais carbonosos preparados têm apresentado elevados valores de adsorção de azul de metileno [Albanez, 2007; Franco, 2003; Raimundo, 2004.]. 


\section{MATERIAIS E MÉTODOS}

\subsection{MATERIAIS}

\subsection{1 - Argila Chocolate}

A argila utilizada é uma bentonita policatiônica, proveniente do município de Boa Vista no estado da Paraíba e denominada localmente de "chocolate". A bentonita natural, conforme extraída da mina foi moída em moinho de facas, desagregada manualmente em almofariz e passada em peneira ABNT $n^{\circ} 20 \mathrm{e}$ $n^{\circ} 100$. $O$ teor de umidade removida em estufa a $110^{\circ} \mathrm{C}$, do material que passou na peneira malha 100 foi em torno de 7\% (base úmida). O material utilizado foi o passante na peneira malha 100 (Figura 7) o qual foi seco a $60^{\circ} \mathrm{C}$ ou a $110^{\circ} \mathrm{C}$.

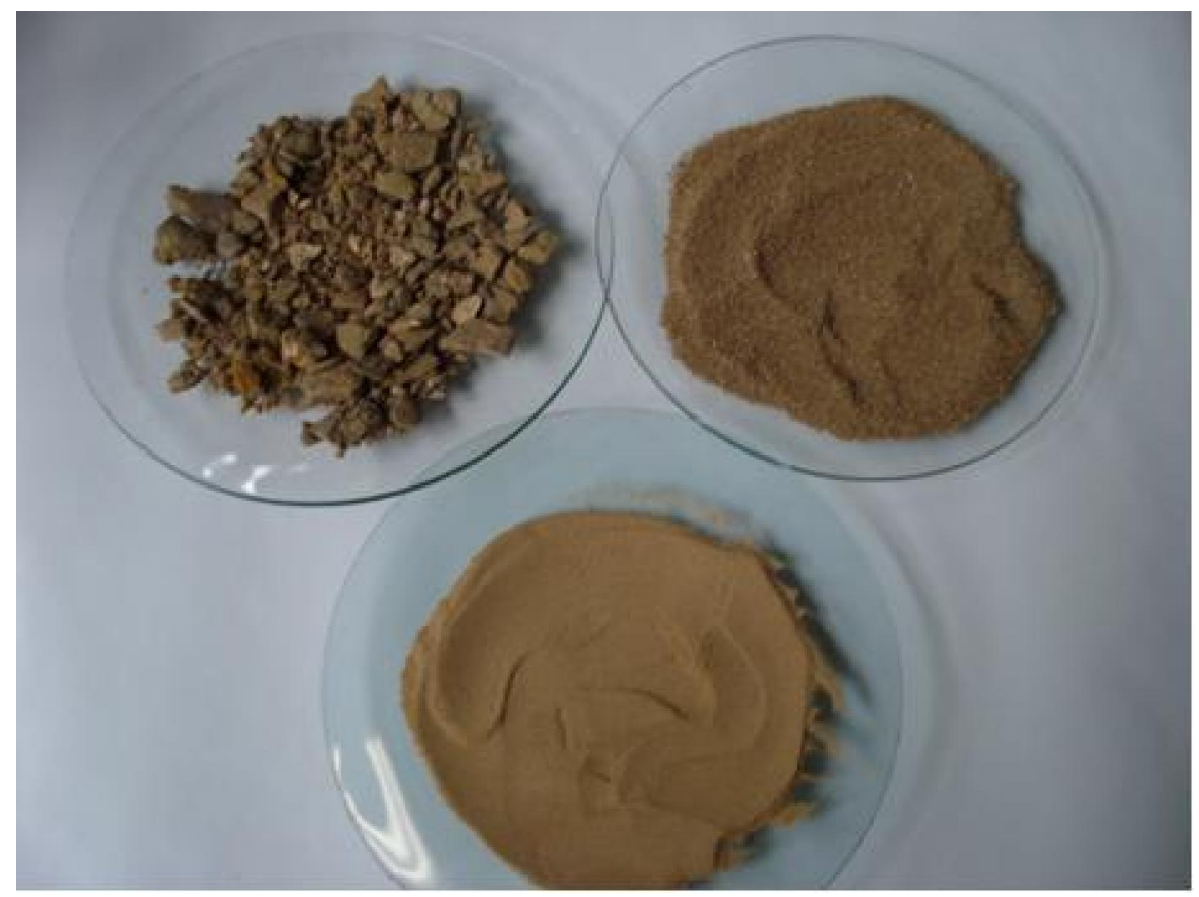

Figura 7 - Argila Chocolate. Acima e esquerda: argila moída no moinho de facas. Acima e direita: a mesma argila moída manualmente e peneirada (passante na malha ABNT $n^{\circ} 20$ e retida na malha 100). Abaixo: ainda a 
mesma argila moída manualmente e peneirada (passante na peneira ABNT $\left.\mathrm{n}^{\circ} 100\right)$.

\subsection{6 - Carbonato de sódio}

O sal utilizado na transformação da bentonita policatiônica em sódica foi o carbonato de sódio $\left(\mathrm{Na}_{2} \mathrm{CO}_{3}\right)$ P.A.

\section{$3.1 .7 \quad$ - Carboidrato}

O carboidrato utilizado é o amido de milho comercial, utilizado em produtos alimentares, marca Maizena.

\subsection{8 - Sacarose}

A sacarose utilizada é o açúcar refinado comercial, utilizado em produtos alimentares, marca Cometa.

\subsection{9 - Carvão Ativo em Pó (CAP)}

Foram utilizados dois tipos de carvão ativo:

a) Carvão ativo pertencente à coleção de amostras do LMPSol, de uso genérico do laboratório e sem denominação de origem e

b) Carvão ativo, na forma de pó, P.A., marca VETEC.

\subsection{6 - Água}

Toda a água utilizada na Tese foi destilada.

\section{2 - MÉTODOS}

\subsection{1 - Método de preparo dos compósitos Argila/Amido, Argila/Sacarose e Argila/Carvão Ativado}

A argila chocolate policatiônica foi transformada em sódica segundo o método descrito por VALENZUELA-DÍAZ (2001), descrito no próximo item. Após esta etapa adicionou-se à argila sódica, diferentes porcentagens de amido de milho (2,5\%; 5,0\%; 10,0\%; $20,0 \%$ e 30,0\% em massa de amido em relação à massa de argila). Utilizou-se também sacarose (2,5\%; 5,0\%; 7,5\%; $10,0 \%$ e 20,0\% em massa de sacarose em relação à massa de argila). Preparou-se, também corpos de prova esféricos com duas proporções de 
carvão ativado (CAP). Na primeira - 83,0 \%, em massa, de carvão ativado e $17,0 \%$ em massa de argila. Na segunda - 75,0 \% de carvão ativado em pó e $25,0 \%$ em massa de argila.

As etapas utilizadas são mostradas no fluxograma a seguir.

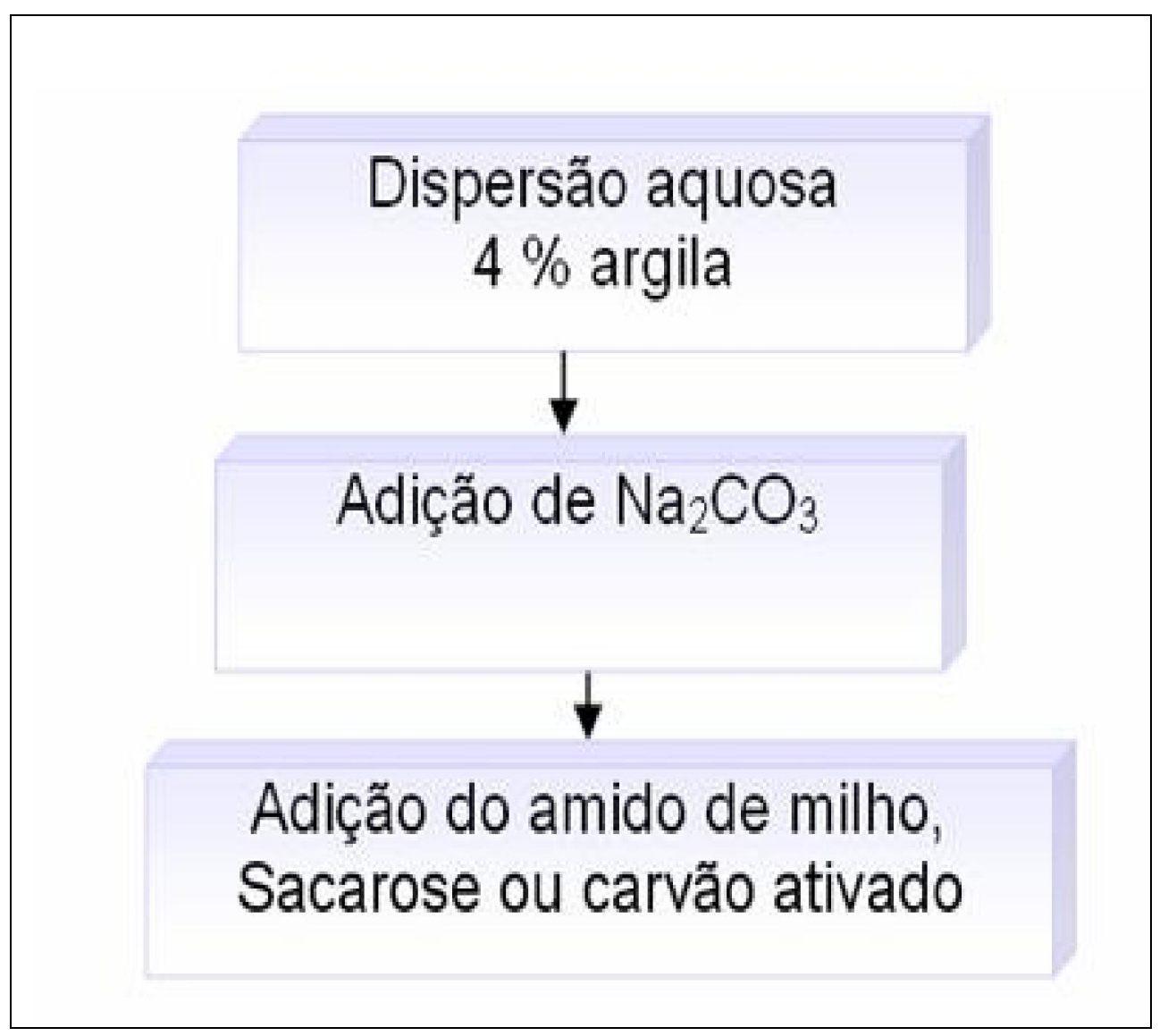

Figura 8 - fluxograma do processo de obtenção dos nanocompósitos argila chocolate /amido de milho; argila chocolate /sacarose e argila chocolate/carvão ativado.

3.2.1.1 - Obtenção da Argila Sódica a Partir da Bentonita Policatiônica

Foram preparadas dispersões (4\%, em massa, de bentonita) com água destilada e argila, sob agitação contínua, por 20 minutos. Após esta etapa, a dispersão ficou em repouso por $48 \mathrm{~h}$. A troca por sódio foi executada a quente 
$\left(98{ }^{\circ} \mathrm{C}\right)$, pela adição de carbonato de sódio $\left(\mathrm{Na}_{2} \mathrm{CO}_{3}\right), 110$ meq $\left(\mathrm{Na}_{2} \mathrm{CO}_{3}\right) / 100$ $\mathrm{g}$ de bentonita. Novamente a dispersão ficou em repouso por $48 \mathrm{~h}$ (Figura 9).

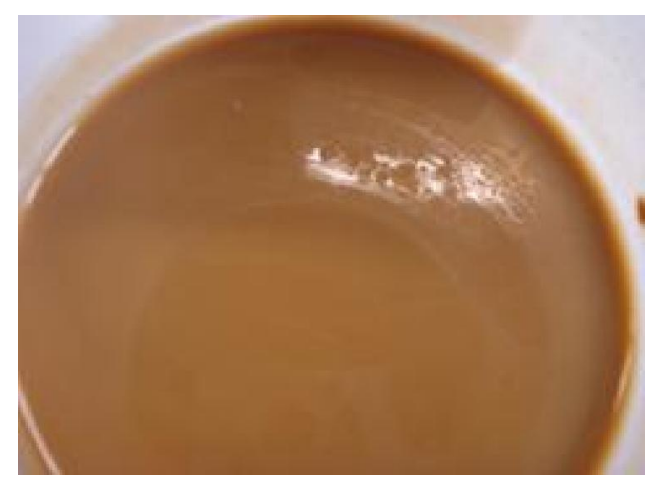

Figura 9 - dispersão aquosa formada pela argila chocolate policatiônica e carbonato de sódio.

3.2.1.2 - Preparação dos Nanocompósitos à base de amido

$\mathrm{Na}$ preparação dos nanocompósitos à base de amido de milho, utilizaram-se dois métodos: No método $\mathrm{A}$, o amido de milho foi misturado com água, na temperatura ambiente, e depois foi aquecido até fervura e obtenção de um gel transparente. Só então foi adicionado na dispersão aquosa contendo a argila chocolate transformada em sódica anteriormente. No método $B, 0$ amido na forma de pó foi adicionado na dispersão aquosa contendo a argila chocolate transformada em sódica anteriormente, sob agitação, na temperatura ambiente.

\section{A - Mistura do amido na forma de gel}

A argila chocolate natural foi moída, em moinho de facas, e seca a $110^{\circ} \mathrm{C}$ por 24 horas. Depois de seca foi feita a troca catiônica por sódio e repouso por $48 \mathrm{~h}$. Após esta etapa, efetuou-se a adição do amido de milho, na forma de um gel, sob agitação e aquecimento constantes. A mistura foi resfriada a temperatura ambiente por $24 \mathrm{~h}$ e submetida à secagem $\left(60^{\circ} \mathrm{C}\right)$, moagem (peneira ABNT $\left.n^{\circ} 100\right)$ e secagem $\left(110^{\circ} \mathrm{C}\right)$ ou queima a 
$350^{\circ} \mathrm{C}$ ou $500^{\circ} \mathrm{C}$ por um patamar de $30 \mathrm{~min}$. (a velocidade de aquecimento em ambos tipos de queima foi de $10^{\circ} \mathrm{C} / \mathrm{min}$.), em atmosfera redutora (cadinho de $50 \mathrm{~mL}$, tampado com placa refratária). As amostras foram caracterizadas e seus resultados comparados aos dos compósito argila-sacarose e argila-carvão ativado.

Foram preparados cinco (5) sistemas contendo bentonita sódica e amido (denominados como B, C, D, E e F), um contendo apenas bentonita sódica (A) e um apenas amido (K). A tabela 7 apresenta as composições percentuais dos diferentes sistemas e a tabela 8 apresenta a nomenclatura utilizada neste trabalho. A viscosidade Brookfield das dispersões tipo A foi medida utilizandose equipamento modelo RT com haste 4 e velocidade de $100 \mathrm{rpm}$.

Tabela 7 - Composição percentual das dispersões contendo argila e amido

\begin{tabular}{ccccc}
\hline Amostra & Água $(\mathrm{g})$ & Argila $(\mathrm{g})$ & Amido $(\mathrm{g})$ & $\%$ amido \\
\hline A & 384,0 & 16 & sem amido & zero \\
\hline B & 384,0 & 16 & 0,4 & 2,5 \\
\hline C & 383,2 & 16 & 0,8 & 5,0 \\
\hline D & 382,5 & 16 & 1,6 & 10,0 \\
\hline E & 380,8 & 16 & 3,2 & 20,0 \\
\hline F & 379,2 & 16 & 4,8 & 30,0 \\
\hline K & 384,0 & zero & 16 & 100,0 \\
\hline
\end{tabular}


Tabela 8 - Nomenclatura das amostras obtidas pela mistura da argila sódica com amido.

\begin{tabular}{|c|c|c|}
\hline Código & $\%$ amido & $\mathrm{T}\left({ }^{\circ} \mathrm{C}\right)$ \\
\hline A 1 & - & 110 \\
\hline A 3 & - & 350 \\
\hline A 5 & - & 500 \\
\hline B 1 & 2,5 & 110 \\
\hline B 3 & 2,5 & 350 \\
\hline B 5 & 2,5 & 500 \\
\hline C 1 & 5,0 & 110 \\
\hline C 3 & 5,0 & 350 \\
\hline C 5 & 5,0 & 500 \\
\hline D 1 & 10,0 & 110 \\
\hline D 3 & 10,0 & 350 \\
\hline D 5 & 10,0 & 500 \\
\hline E 1 & 20,0 & 110 \\
\hline E 3 & 20,0 & 350 \\
\hline E 5 & 20,0 & 500 \\
\hline $\mathrm{F} 1$ & 30,0 & 110 \\
\hline F 3 & 30,0 & 350 \\
\hline F 5 & 30,0 & 500 \\
\hline K 1 & 100,0 & 110 \\
\hline K 3 & 100,0 & 350 \\
\hline K 5 & 100,0 & 500 \\
\hline
\end{tabular}

Obs.: $\mathrm{O}$ tempo de secagem para $\mathrm{T}$ de $110^{\circ} \mathrm{C}$ foi de $24 \mathrm{~h}$. As amostras queimadas a $350^{\circ} \mathrm{C}$ ou $500^{\circ} \mathrm{C}$ permaneceram no patamar por um período de $30 \mathrm{~min}$. 
B - Mistura do amido em pó

A argila chocolate natural foi moída, em moinho de facas, e seca a $60^{\circ} \mathrm{C}$ por 24 horas. Depois de seca foi feita a troca catiônica por sódio e repouso por 48 h. Após esta etapa, efetuou-se a adição do amido de milho, sob agitação e aquecimento constantes. A mistura foi resfriada a temperatura ambiente por 24 h e submetida à secagem $\left(60^{\circ} \mathrm{C}\right)$, moagem (peneira ABNT $\left.n^{\circ} 100\right)$ e secagem $\left(110^{\circ} \mathrm{C}\right.$ por $\left.24 \mathrm{~h}\right)$ ou queima a $350^{\circ} \mathrm{C}$ ou $a$ $500 \stackrel{\circ}{\circ}$ e patamar de $30 \mathrm{~min}$, velocidade de aquecimento nos dois tipos de queima foi de $10^{\circ} \mathrm{C} / \mathrm{min}$., em atmosfera redutora (cadinho de $50 \mathrm{~mL}$, tampado com placa refratária). As amostras foram caracterizadas e seus resultados comparados aos dos compósito argila-sacarose e argila-carvão ativado.

O ensaio foi feito em duplicata (denominadas como ASA - 2 e ASA - 5 ) . A tabela 9 apresenta a composição percentual deste sistema.

A porcentagem de amido escolhida para o procedimento B foi de $20 \%$ pois foi o teor de amido no procedimento $A$ que apresentou melhor resultado no ensaio de adsorção.

Tabela 9 - Composição percentual da dispersão contendo argila e amido

\begin{tabular}{ccccc}
\hline Amostra & Água $(\mathrm{g})$ & Argila $(\mathrm{g})$ & Amido $(\mathrm{g})$ & $\%$ amido \\
\hline ASA - 2 & 480,0 & 20 & 4 & 20,0 \\
\hline ASA - 5 & 480,0 & 20 & 4 & 20,0 \\
\hline
\end{tabular}

3.2.1.3 - Preparação dos Nanocompósitos à base de sacarose

Para a preparação dos nanocompósitos argila/sacarose, adotou-se os mesmos métodos utilizados na preparação dos nanocompósitos argila/amido de milho. No procedimento A - argila seca a $110^{\circ} \mathrm{C}$ por 24 horas - preparou-se um xarope de açúcar com água e, depois este xarope foi adicionado na dispersão aquosa contendo a argila chocolate transformada em sódica anteriormente. No procedimento $B-$ argila seca a $60^{\circ} \mathrm{C}$ por 24 horas o açúcar 
foi adicionado na dispersão aquosa contendo a argila chocolate transformada em sódica anteriormente.

\section{A - Mistura da sacarose na forma de xarope}

A adição da sacarose foi feita na dispersão aquosa de argila sódica. Para isto, adicionou-se a massa de sacarose (dissolvido em água) na dispersão sob aquecimento e agitação constantes. As misturas foram resfriadas naturalmente em ambiente de laboratório. Depois foram secas $\left(110^{\circ} \mathrm{C}\right)$, moídas e tratadas termicamente a $350^{\circ} \mathrm{C}$ e $500^{\circ} \mathrm{C}$ em atmosfera redutora (cadinho de $50 \mathrm{~mL}$ tampado com placa refratária), velocidade de aquecimento de $10^{\circ} \mathrm{C} / \mathrm{min}$. e patamar de $30 \mathrm{~min}$. As amostras foram caracterizadas e seus resultados comparados aos do compósito argila-amido e argila-carvão ativado.

Foram preparados quatro (4) sistemas contendo bentonita sódica e sacarose (denominados como ASS-A, ASS-B, ASS-C e ASS-D). A tabela 10 apresenta as composições percentuais dos diferentes sistemas e a tabela 11 apresenta a nomenclatura destas amostras.

Tabela 10 - Composição percentual das dispersões contendo argila e sacarose

\begin{tabular}{ccccc}
\hline Amostra & Água $(\mathrm{g})$ & Argila $(\mathrm{g})$ & Sacarose $(\mathrm{g})$ & $\%$ sacarose \\
\hline ASS-A & 384,0 & 16 & 0,4 & 2,5 \\
\hline ASS-B & 384,0 & 16 & 0,8 & 5,0 \\
\hline ASS-C & 383,0 & 16 & 1,2 & 7,5 \\
\hline ASS-D & 382,5 & 16 & 1,6 & 10,0 \\
\hline
\end{tabular}


Tabela 11 - Nomenclatura das amostras obtidas pela mistura da argila sódica com sacarose

\begin{tabular}{ccc}
\hline Código & \% sacarose & $\mathrm{T}\left({ }^{\circ} \mathrm{C} / 30 \mathrm{~min}\right)$ \\
\hline ASS - A & 2,5 & 350 \\
\cline { 2 - 3 } & & 500 \\
\hline ASS - B & 5,0 & 350 \\
\hline ASS - C & 500 \\
\hline ASS - D & 7,5 & 350 \\
\hline
\end{tabular}

B - Mistura da sacarose em pó

A adição da sacarose foi feita na dispersão aquosa de argila sódica. Para isto, adicionou-se a massa de sacarose na dispersão sob aquecimento e agitação constantes. As misturas foram resfriadas naturalmente em ambiente de laboratório. Depois foram secas, moídas e tratadas termicamente a $350^{\circ} \mathrm{C}$ e $500^{\circ} \mathrm{C}$, em atmosfera redutora (cadinho de $50 \mathrm{~mL}$ tampado com placa refratária) com velocidade de aquecimento de 10C/min e patamar de $30 \mathrm{~min}$. As amostras foram caracterizadas e seus resultados comparados aos do compósito argila-amido e argila-carvão ativado.

Foi preparado (1) sistema contendo bentonita sódica e $20 \%$ de sacarose, igual ao procedimento B da adição de amido de milho. A tabela 12 apresenta a composição percentual deste sistema e a tabela 13 apresenta a nomenclatura desta amostra. 
Tabela 12 - Composição percentual da dispersão contendo argila e sacarose

\begin{tabular}{ccccc}
\hline Amostra & Água $(\mathrm{g})$ & Argila $(\mathrm{g})$ & Amido $(\mathrm{g})$ & $\%$ sacarose \\
\hline ASS-E & 480,0 & 20 & 4 & 20,0 \\
\hline
\end{tabular}

Tabela 13- Nomenclatura das amostras obtidas pela mistura da argila sódica com sacarose

\begin{tabular}{ccc}
\hline Código & $\%$ sacarose & $\mathrm{T}\left({ }^{\circ} \mathrm{C} / 30 \mathrm{~min}\right)$ \\
\hline ASS-E & 20 & 350 \\
\cline { 2 - 3 } & & 500 \\
\hline
\end{tabular}

\subsubsection{4 - Preparação dos Compósitos à base de carvão ativado}

A quantidade de carvão ativado possível de ser adicionada na dispersão depende da quantidade de água presente na mistura. Assim, obteve-se duas porcentagens diferentes de carvão ativado em relação à quantidade de argila utilizada. Na primeira - denominada de procedimento A - a porcentagem utilizada foi de $83 \%$ de carvão em relação à argila, em massa seca. $\mathrm{Na}$ segunda - denominada de procedimento B - obteve-se 75 \% de carvão ativado em relação à argila, em massa seca.

A adição do carvão foi feita na dispersão aquosa de argila sódica. Para isto, adicionou-se a massa de carvão, na forma de pó, na dispersão. Colocou-se o carvão até ser possível moldar, manualmente, esferas de mais ou menos $2 \mathrm{~cm}$ de diâmetro, que foram deixadas para secar em temperatura ambiente por 24 horas. Depois foram secas a $60^{\circ} \mathrm{C}$ por $24 \mathrm{~h}$ e a seguir a $110^{\circ} \mathrm{C}$ também por 24 h. Após esta etapa, as amostras foram queimadas a diferentes temperaturas. As amostras foram caracterizadas e seus resultados comparados aos do compósito argila-amido e argila-sacarose.

O carvão utilizado no procedimento $A$ foi um material genérico pertencente à coleção do LMPSOL e sem denominação de origem, enquanto que para o procedimento B utilizou-se um material PA, marca VETEC. Outra diferença 
entre os dois procedimentos foi com relação à temperatura de secagem da argila chocolate. No procedimento $A$, a argila foi seca à $110^{\circ} \mathrm{C}$, enquanto que no $\mathrm{B}$, a $60^{\circ} \mathrm{C}$.

No procedimento A foram preparadas vinte (20) amostras contendo bentonita sódica e carvão ativado (numeradas de 1 a 20). A tabela 14 apresenta as temperaturas de queima das amostras. No procedimento $B$, obtiveram-se apenas nove (9) esferas (numeradas de 21 a 29). Optou-se por se trabalhar com apenas três temperaturas de queima $-500^{\circ} \mathrm{C}, 750^{\circ} \mathrm{C}$ e $900^{\circ} \mathrm{C}$ pois, notou-se que a resistência mecânica era melhor - ver tabelas 14 e 15. A velocidade de aquecimento nas queimas foi de $10^{\circ} \mathrm{C} / \mathrm{min}$. Atmosfera redutora (amostra em cadinho de $50 \mathrm{~mL}$, coberta com alumina em pó e o cadinho tampado com placa refratária) e patamar de $30 \mathrm{~min}$. Para o Procedimento A e sem patamar no Procedimento B (Figura 10). Algumas das esferas foram submetidas a ensaio mecânico de compressão, considerando-se a tensão de ruptura como a carga de ruptura dividida pela área da seção transversal.

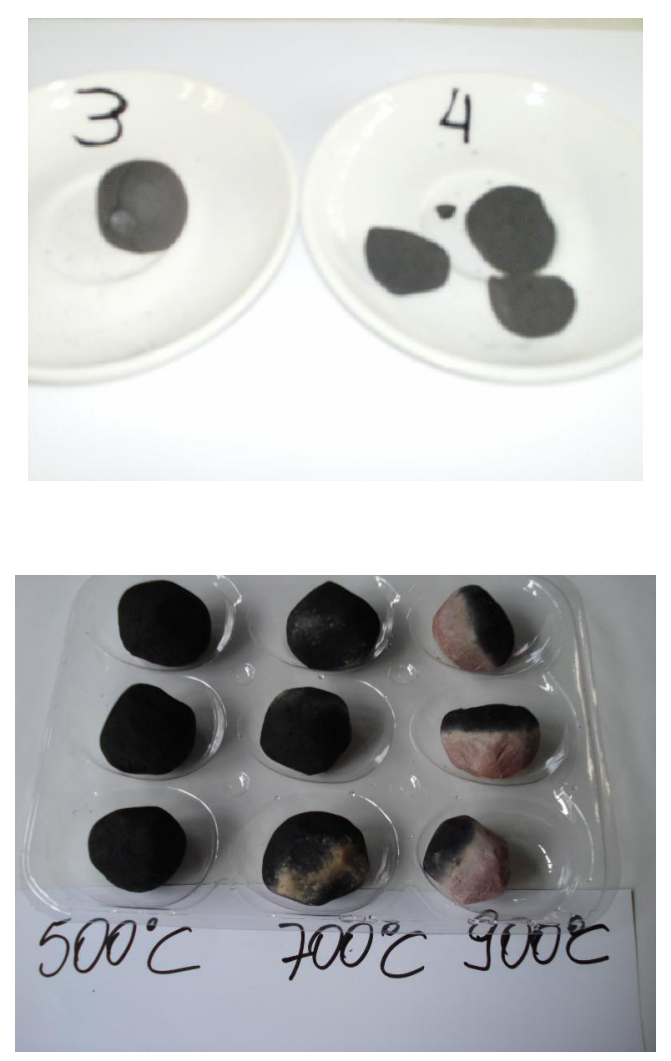

Figura 10 - corpos esféricos compostos por argila e carvão ativado. 
Tabela 14 - Temperaturas de queima das amostras argila-carvão ativado, procedimento $A$.

\begin{tabular}{|c|c|}
\hline Temperatura & Amostras \\
\hline \multirow{4}{*}{$110^{\circ} \mathrm{C}$} & 1 \\
\hline & 2 \\
\hline & 3 \\
\hline & 4 \\
\hline \multirow{4}{*}{$350 \stackrel{\circ}{C}$} & 5 \\
\hline & 6 \\
\hline & 7 \\
\hline & 8 \\
\hline \multirow{4}{*}{$500^{\circ} \mathrm{C}$} & 9 \\
\hline & 10 \\
\hline & 11 \\
\hline & 12 \\
\hline \multirow{4}{*}{$750^{\circ} \mathrm{C}$} & 13 \\
\hline & 14 \\
\hline & 15 \\
\hline & 16 \\
\hline \multirow{4}{*}{$900^{\circ} \mathrm{C}$} & 17 \\
\hline & 14 \\
\hline & 15 \\
\hline & 16 \\
\hline
\end{tabular}


Tabela 15 - Temperaturas de queima das amostras argila-carvão ativado, procedimento $\mathrm{B}$.

\begin{tabular}{|c|c|}
\hline Temperatura & Amostras \\
\hline \multirow{3}{*}{$500 \circ \mathrm{C}$} & 21 \\
\hline & 22 \\
\hline & 23 \\
\hline \multirow{3}{*}{$750 \cong \mathrm{C}$} & 24 \\
\hline & 25 \\
\hline & 26 \\
\hline \multirow{3}{*}{$900 \cong \mathrm{C}$} & 27 \\
\hline & 28 \\
\hline & 29 \\
\hline
\end{tabular}




\section{3 - TÉCNICAS DE CARACTERIZAÇÃO}

\subsection{1 - Caracterização}

Caracterizar uma argila, especialmente visando seu uso tecnológico, é conhecer a variabilidade de suas propriedades, o que não é tão simples, pois, é necessário o emprego de técnicas não apenas comuns, como também as mais trabalhosas e as mais sofisticadas [Pereira, 2008].

Todas as técnicas fornecem informações que se completam. Dentre os diversos métodos empregados na caracterização, a seguir serão apresentados os que foram utilizados nesta tese.

\subsubsection{1 - Difração de Raios-X (DRX)}

A Difração de Raios-X (DRX) é a técnica que fornece informações mais amplas, precisas e detalhadas quanto à qualificação, caracterização e quantificação dos constituintes presentes numa argila, além disso, é uma técnica de análise não destrutiva, rápida e muito versátil, tendo apenas o obstáculo de não se poder aplicar a minerais não cristalinos ou com cristalinidade incipiente. Nas argilas o número destes minerais é pouco significativo [Pereira, 2008].

As análises foram realizadas no Laboratório de Matérias-Primas Particuladas e Sólidos Não-Metálicos do Departamento de Engenharia Metalúrgica e de Materiais da Escola Politécnica da Universidade de São Paulo (LMPSol/PMT/EPUSP).

Foi utilizado o método de varredura, que consiste na incidência dos raios-X sobre uma amostra em forma de pó, compactado sobre um suporte. $\mathrm{O}$

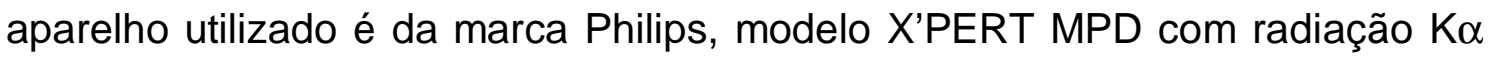
do cobre, tensão de $40 \mathrm{KV}$, corrente de $40 \mathrm{~mA}$, tamanho do passo de $0,0202 \Theta \mathrm{e}$ tempo por passo de 1,000s. 


\subsubsection{2 - $\quad$ Análise Térmica (AT)}

Análise térmica é um termo que abrange um grupo de técnicas nas quais uma propriedade física ou química de uma substância, ou de seus produtos de reação, é monitorada em função do tempo ou temperatura, enquanto a temperatura da amostra, sob uma atmosfera específica, é submetida a uma programação controlada.

As análises térmicas foram realizadas em equipamento simultâneo de termogravimetria (TG) e análise térmica diferencial (DTA) da TA Instruments, modelo SDT Q600 do Departamento de Engenharia Química da Escola Politécnica da Universidade de São Paulo (PQI/EPUSP) e as condições de realização da análise foram:

Gás de purga: Nitrogênio.

Vazão do gás: $100 \mathrm{~mL} / \mathrm{min}$.

Taxa de aquecimento: $10^{\circ} \mathrm{C} / \mathrm{min}$.

Temperatura final: $1000^{\circ} \mathrm{C}$.

\subsubsection{3 - Microscopia Eletrônica de Varredura (MEV)}

Nos últimos 15 anos, tem havido um grande desenvolvimento e aperfeiçoamento dos métodos e equipamentos ópticos-eletrônicos usados na caracterização de materiais sólidos, em especial os argilominerais em argilas e solos.

A microscopia eletrônica é a técnica indicada para o estudo das formas dos cristais individuais dos minerais argilosos e permite o exame de superfícies, sendo adequada para o estudo de texturas [Pereira, 2008].

A amostra na forma de pó foi recoberta com uma fina camada de ouro (por ser bom condutor de elétrons) por um metalizador e fixada ao porta-amostra por uma fita adesiva de carbono. As micrografias foram obtidas no microscópio eletrônico de varredura da marca Philips, modelo XL30 EDAX do Laboratório de Microscopia Eletrônica do Departamento de Engenharia Metalúrgica e de Materiais da Escola Politécnica da Universidade de São Paulo (LMPSol/PMT/EPUSP).

\subsubsection{4 - Capacidade de sorção - Sorção (Ad/absorção) de Azul de}

Metileno (AM) 
A técnica utilizada para analisar a adsorção do AM consiste em adicionar, em um frasco de vidro com tampa, $20 \mathrm{~mL}$ de solução aquosa de AM com diferentes concentrações $(0,05 \mathrm{~g} / \mathrm{L}$ a $0,1 \mathrm{~g} / \mathrm{L})$ e $0,05 \mathrm{~g}$ de amostra. Após a homogeinização manual deixa-se em repouso por 24 horas em estufa a 90 oC. Caso o sobrenadante apresente - por observação visual - turbidez ou qualquer tonalidade de cor, a amostra é considerada não adsorvente. Entretanto, se o sobrenadante se apresentar límpido, aumenta-se a concentração da solução de AM ou diminui-se a quantidade de amostra até obter-se um sobrenadante com tonalidade azul. Calcula-se a quantidade de AM adsorvida por grama de amostra da última dispersão a apresentar sobrenadante sem coloração azul.

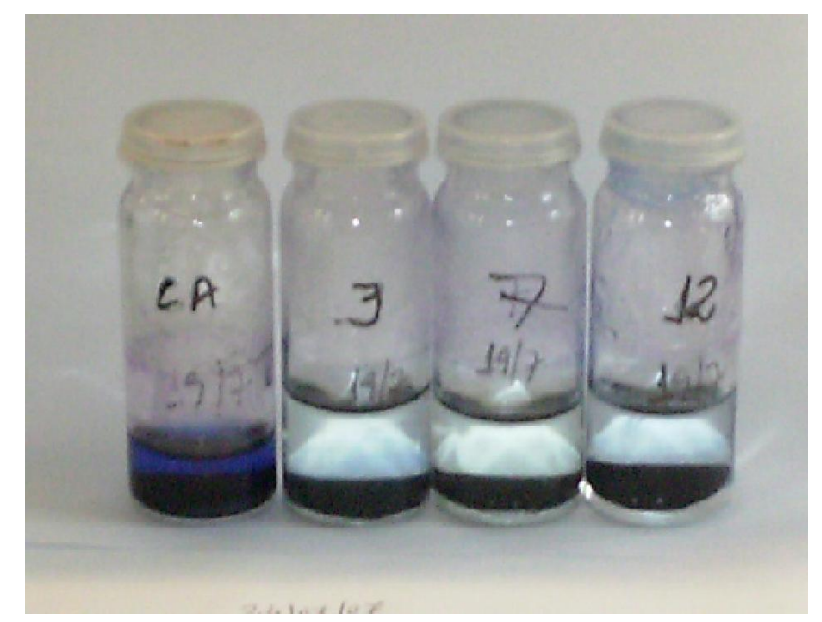

Figura 11 - adsorção de azul de metileno. Adsorvato: carvão ativado, compósitos argila/carvão ativado (83\% em massa de carvão). 


\subsubsection{5 - Espectrofotometria}

As amostras das soluções obtidas no ensaio de sorção de azul de metileno foram analisadas em espectrofotômetro de absorção marca Varian, modelo CARY-50-PROBE, varrendo os comprimentos de onda na faixa de 400 a 800 nanômetros. O equipamento pertence ao Laboratório de Fotoquímica do Departamento de Engenharia Química da Escola Politécnica da Universidade de São Paulo (PQI/EPUSP).

\subsubsection{6 - Área superficial específica}

A determinação da área superficial específica - área superficial por unidade de massa - é feita a partir da medida da área superficial de um grande número de partículas. Esta medida é de muita utilidade porque está frequentemente relacionada com várias características cinéticas e geométricas. Quando se trata de atividade química, catálise, fricção, adsorção, contaminação, prensagem e sinterização, a superfície específica fornece informações importantes sobre o comportamento dos materiais [Albanez, 1996].

Foi medida a área superficial específica de uma amostra do compósito argila/carvão ativado em pó ( $75 \%$ em carvão) e queimada a $500^{\circ} \mathrm{C}$. O equipamento utilizado foi o analisador ASAP 2010, marca Micromeritics. O equipamento pertence ao Laboratório de Matérias-Primas Particuladas e Sólidos Não Metálicos (LMPSOL) da Escola Politécnica da Universidade de São Paulo (PMT/EPUSP). 


\section{RESULTADOS E DISCUSSÃO}

Neste capítulo serão apresentados e discutidos os resultados das caracterizações da argila esmectítica e dos nanocompósitos formados entre esta argila e os materiais carbonosos utilizados nesta pesquisa (amido de milho, sacarose e carvão ativado em pó).

\subsection{MÉTODOS DE CARACTERIZAÇÃO}

\subsection{1 - Viscosidade}

As análises de viscosidade das dispersões contendo argila foram executadas com o viscosímetro Brookfield. Os valores estão na tabela 16.

Tabela 16 - Medidas de viscosidade

Amostra Viscosidade (cP)- $100 \mathrm{rpm}$ Viscosidade (cP)- $100 \mathrm{rpm}$ Sem amido Com amido

\begin{tabular}{ccc}
\hline A & 28 & Dispersão sem amido \\
\hline B & 25 & 28 \\
\hline C & 26 & 28 \\
\hline D & 32 & 30 \\
\hline E & 32 & 32 \\
\hline F & 28 & 40 a 60 \\
\hline
\end{tabular}

A viscosidade das dispersões aquosas a $4 \%$ de argila sodificada variaram entre 25 e $32 \mathrm{cP}$. As dispersões contendo entre $2,5 \%$ e $20 \%$ de amido não apresentaram variações expressivas em relação às dispersões sem amido. A partir $30 \%$ de amido houve um aumento da viscosidade, sendo que a dispersão se apresentou instável com viscosidades variando entre 40 e $60 \mathrm{cP}$. Isto ocorre devido ao aumento da interação físico-química ou mecânica das moléculas de amido com o aumento da concentração do mesmo. 


\subsection{2 - Difração de Raios - X (DRX)}

São apresentados nas tabelas 16 e 17 os resultados dos ensaios de Difração de Raios -X (DRX) da argila chocolate, dos nanocompósitos de argila chocolate com amido de milho e sacarose e nas Figuras de 12 a 16 algumas das curvas de raios- $X$.

\subsubsection{1 - $\quad$ Argila Chocolate}

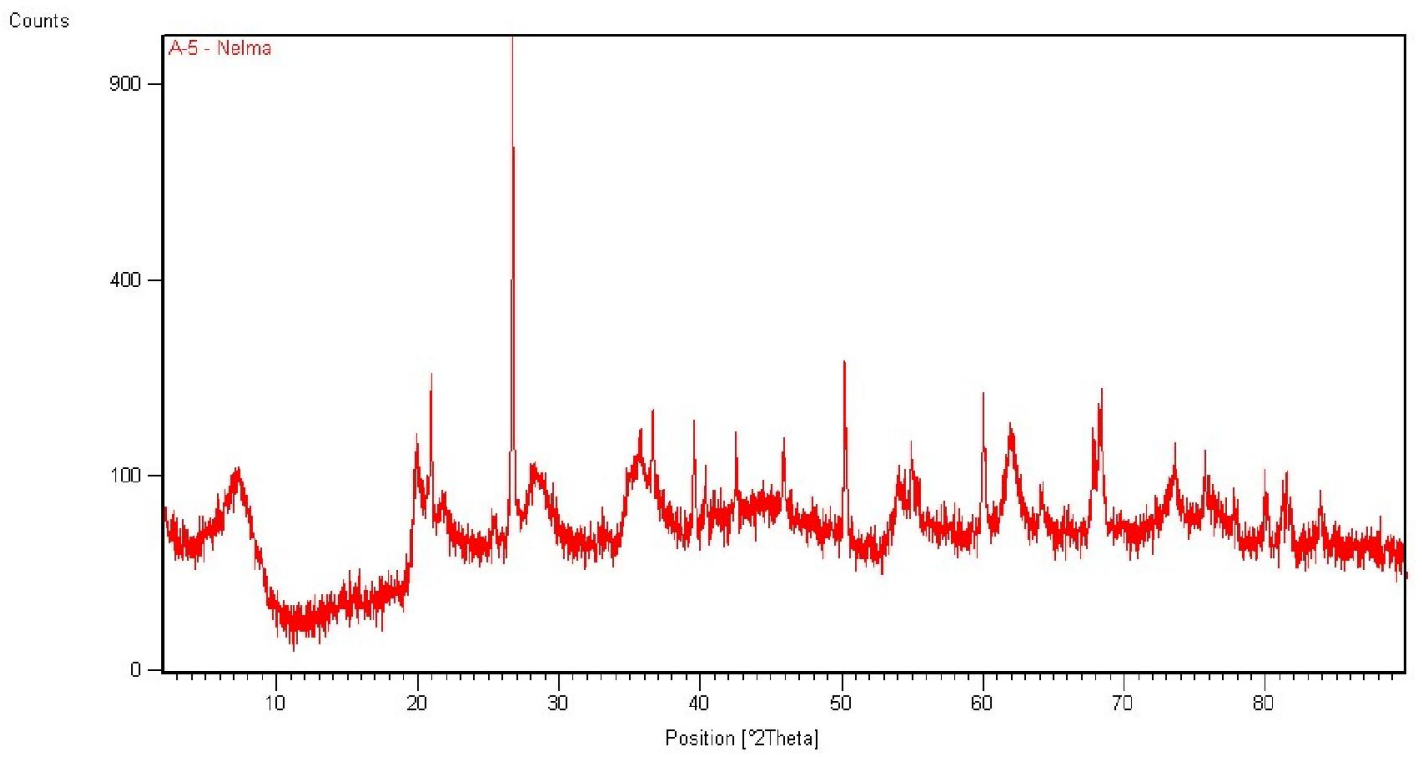

Figura 12 - curva de raios- $X$ da argila chocolate queimada a $500^{\circ} \mathrm{C}$ por 30 min. 4.1.2.2 - Nanocompósitos de argila chocolate com amido de milho

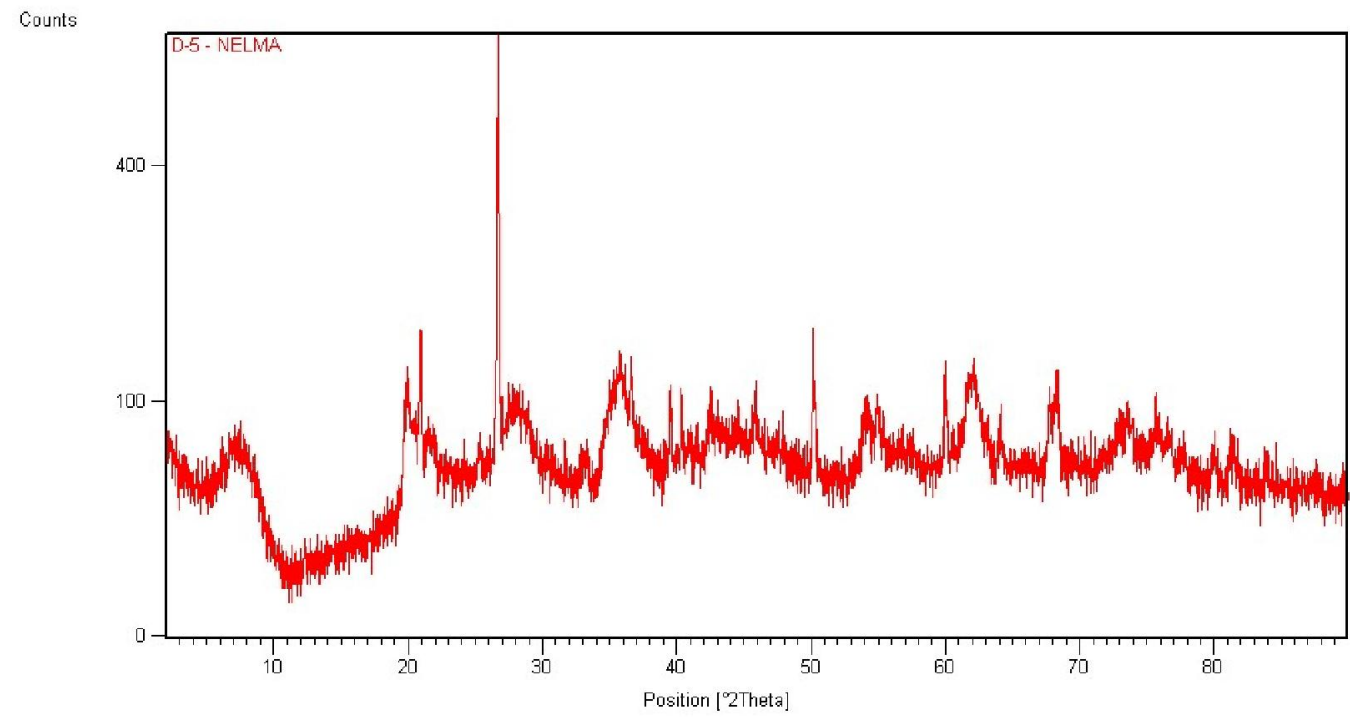

Figura 13- curva de raios- $X$ de $D R X$ do nanocompósito argila chocolate/amido de milho - amostra D-5 (10\% de amido em relação à massa de argila), queimada a $500^{\circ} \mathrm{C}$ por $30 \mathrm{~min}$. 


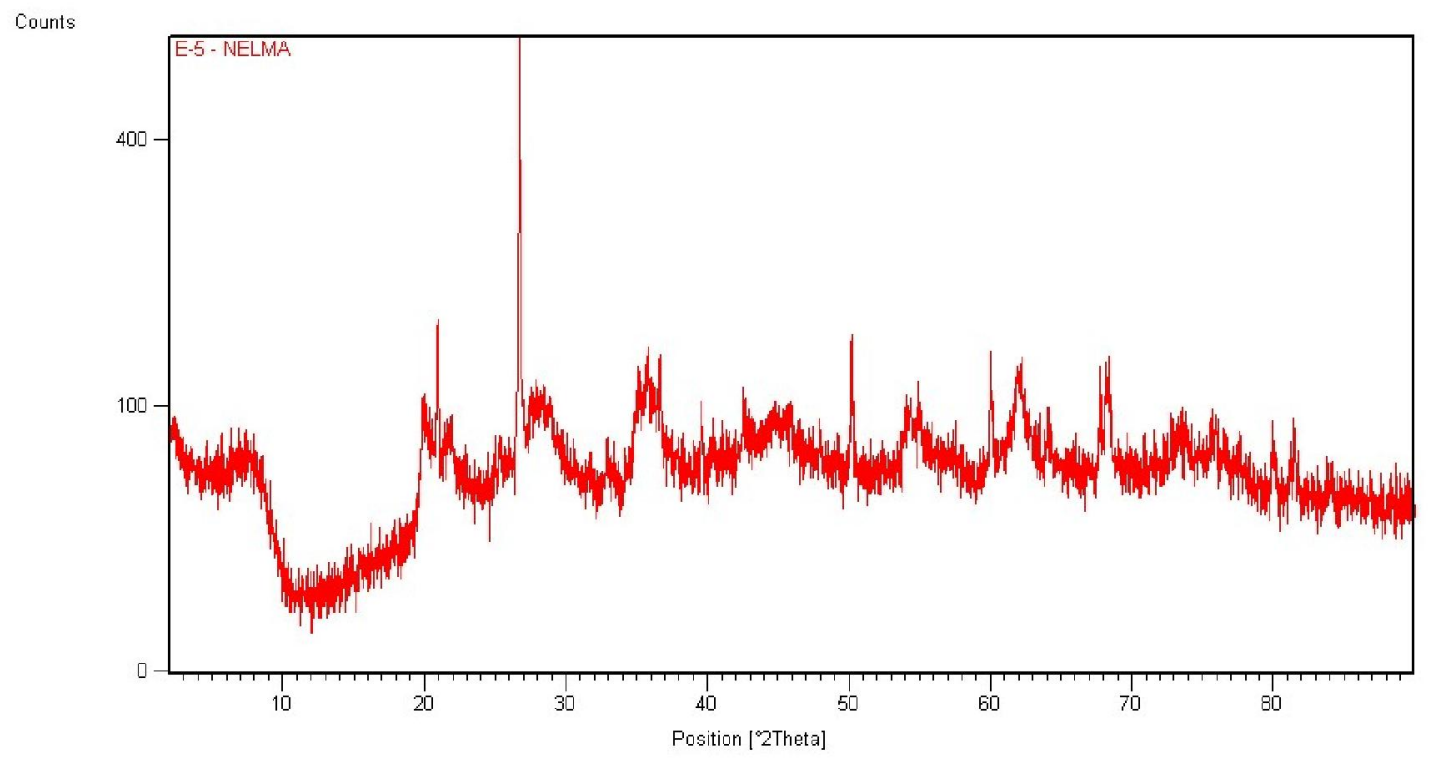

Figura 14 - curva de raios-X de DRX do nanocompósito argila chocolate/amido de milho - amostra E-5 (20\% de amido em relação à massa de argila), queimada a $500^{\circ} \mathrm{C}$ por $30 \mathrm{~min}$. 
Tabela 17 - Distância Basal das amostras contendo argila chocolate e argila chocolate / amido de milho

\begin{tabular}{|c|c|c|c|}
\hline Código & $\%$ amido & $\mathrm{T}\left({ }^{\circ} \mathrm{C} / 30 \mathrm{~min}\right)$ & Distância Basal $(\AA ̊)$ \\
\hline$A-1$ & - & 110 & 13,6 \\
\hline$A-3$ & - & 350 & 10,5 \\
\hline$A-5$ & - & 500 & 10,0 \\
\hline$B-1$ & & 110 & 12,6 \\
\hline$B-3$ & 2,5 & 350 & 12,3 \\
\hline B -5 & & 500 & 11,0 \\
\hline$C-1$ & & 110 & 12,3 \\
\hline$C-3$ & 5,0 & 350 & 12,3 \\
\hline$C-5$ & & 500 & 11,7 \\
\hline$D-1$ & & 110 & 12,6 \\
\hline$D-3$ & 10,0 & 350 & 12,6 \\
\hline$D-5$ & & 500 & 12,3 \\
\hline$E-1$ & & 110 & 12,7 \\
\hline$E-3$ & 20,0 & 350 & 12,3 \\
\hline$E-5$ & & 500 & 12,0 \\
\hline$F-1$ & & 110 & 13,2 \\
\hline$F-3$ & 30,0 & 350 & 12,3 \\
\hline$F-5$ & & 500 & 12,3 \\
\hline $\mathrm{K}-1$ & & 110 & Pico mais intenso a 3,9 \\
\hline$K-3$ & 100,0 & 350 & Pico mais intenso a 3,7 \\
\hline$K-5$ & & 500 & Pico mais intenso a 3,9 \\
\hline
\end{tabular}

Analisando-se as curvas de raios- $\mathrm{X}$ apresentadas nas figuras 11, 12, 13 e 14 os valores mostrados na tabela 16 , pode-se concluir que houve a intercalação do material 
carbonáceo entre as lamelas de argila uma vez que a estrutura não colapsou e as distâncias interplanares foram maiores que $10 \AA$. Nota-se, também, que há pouca interferência do amido nos compósitos de argila e amido, pois os picos mais intensos do amido apresentam valores muito menores que os da argila e argila/amido.

\subsubsection{3 - $\quad$ Nanocompósitos de argila chocolate com sacarose}

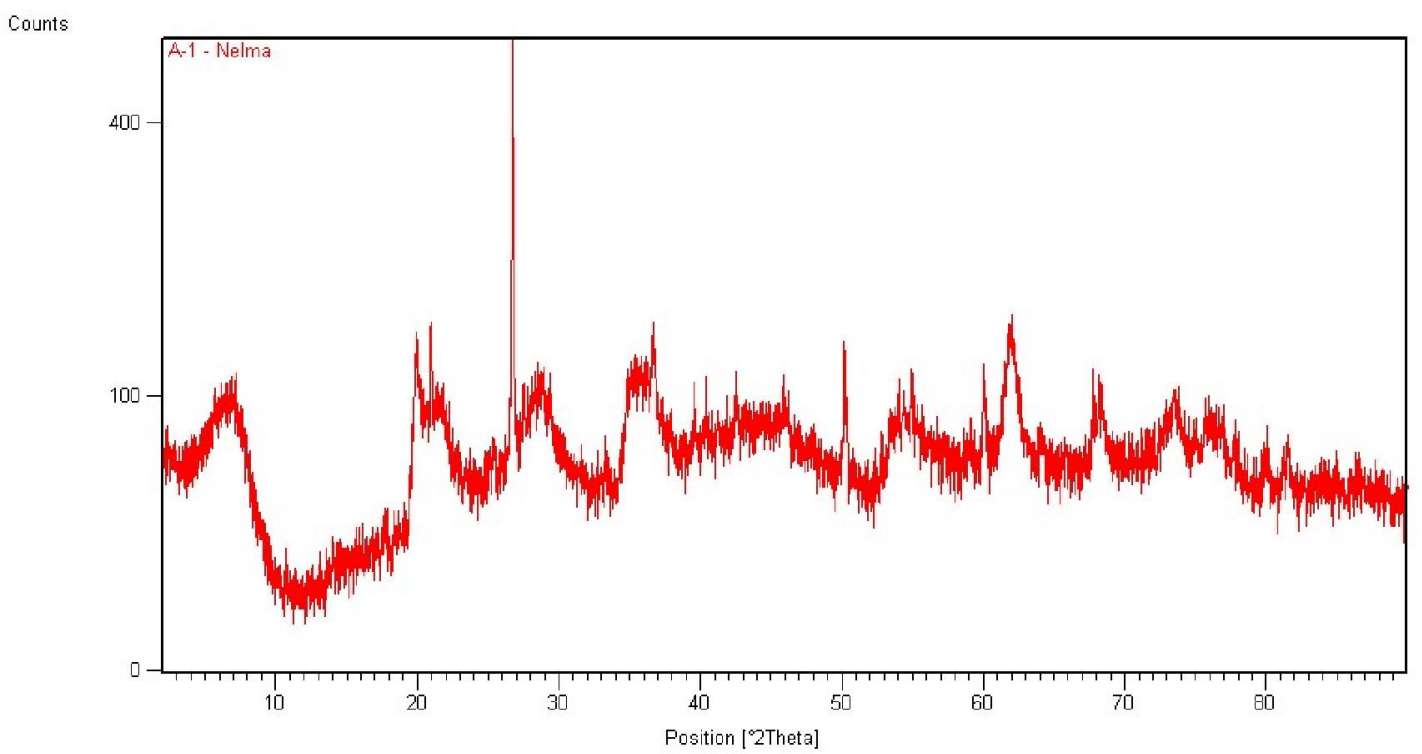

Figura 15 - curva de raios-X de DRX do nanocompósito argila chocolate/sacarose - amostra ASS-B (5\% de sacarose em relação à massa de argila), queimada a $500^{\circ} \mathrm{C}$ por $30 \mathrm{~min}$.

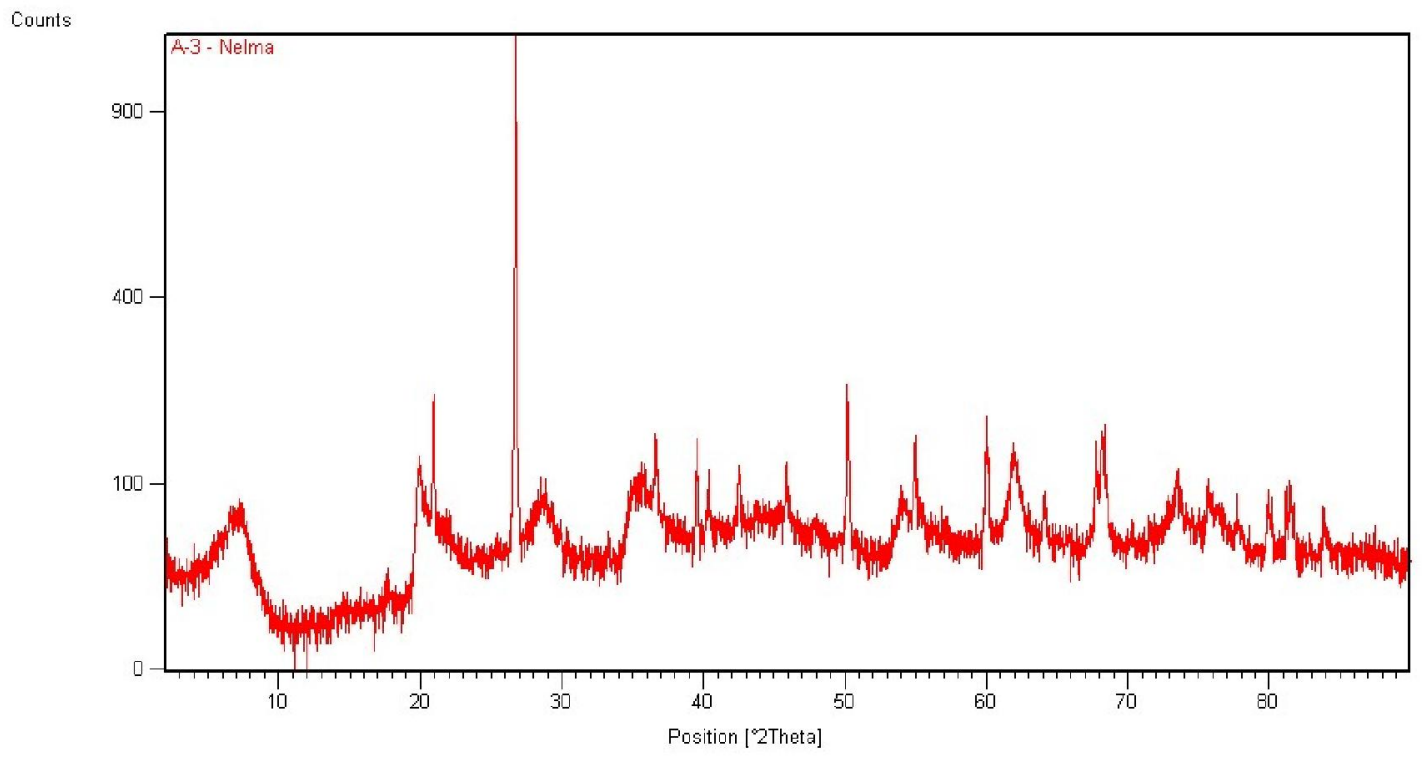

Figura 16 - curva de raios-X de DRX do nanocompósito argila chocolate/sacarose - amostra ASS-D (10\% de sacarose em relação à massa de argila), queimada a $500^{\circ} \mathrm{C}$ por $30 \mathrm{~min}$. 
Tabela 18 - Distância Basal das amostras contendo argila chocolate e argila chocolate / sacarose

\begin{tabular}{|c|c|c|c|}
\hline Código & $\%$ sacarose & $\mathrm{T}\left({ }^{\circ} \mathrm{C} / 30 \mathrm{~min}\right)$ & Distância Basal $(\AA)$ \\
\hline \multirow[t]{2}{*}{ ASS - 1} & - & 350 & 10,5 \\
\hline & & 500 & 10,0 \\
\hline \multirow[t]{2}{*}{ ASS - 2} & 2,5 & 350 & 10,4 \\
\hline & & 500 & 10,4 \\
\hline \multirow[t]{2}{*}{ ASS - 4} & 5,0 & 350 & 11,2 \\
\hline & & 500 & 11,1 \\
\hline \multirow[t]{2}{*}{ ASS - 5} & 10,0 & 350 & 13,3 \\
\hline & & 500 & 12,2 \\
\hline \multirow{3}{*}{$S$} & & Ambiente & Pico principal a 3,5 \\
\hline & 100,0 & 350 & Estrutura amorfa \\
\hline & & 500 & Estrutura amorfa \\
\hline
\end{tabular}

Pelos valores apresentados na tabela 17 , e nas curvas de raios-X mostradas nas figuras 14 e 15, observa-se que: para quantidades menores que 5\% de sacarose, as amostras colapsaram, isto é, não houve a intercalação da sacarose. Quando o teor de sacarose aumentou, (5\% e 10\%) obteve-se nanocompósitos.

\subsection{3 - Análise Térmica}

São apresentados os resultados dos ensaios de Análise Térmica dos nanocompósitos de argila chocolate com carvão ativado em pó (CAP). 
4.1.3.1 - Compósitos de argila chocolate com carvão ativado

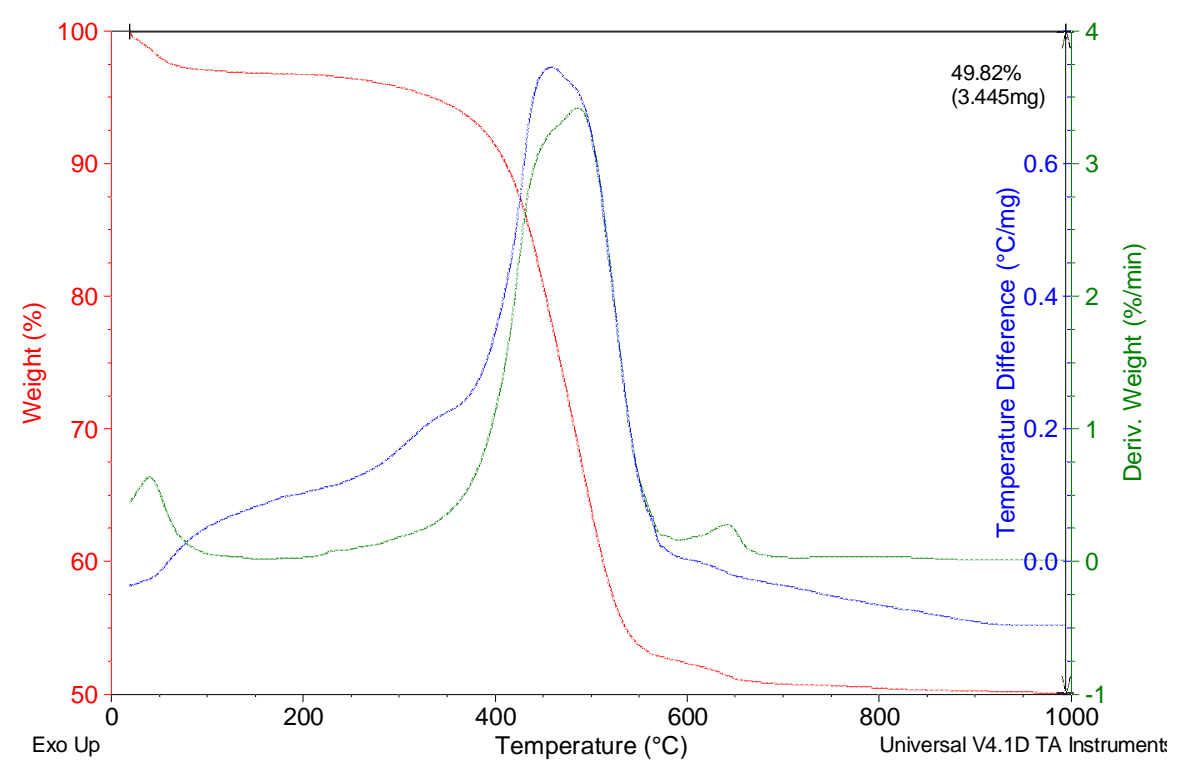

Figura 17 - amostra 3 (carvão ativado genérico 83\%), seca a $110^{\circ} \mathrm{C}$ por 24 horas

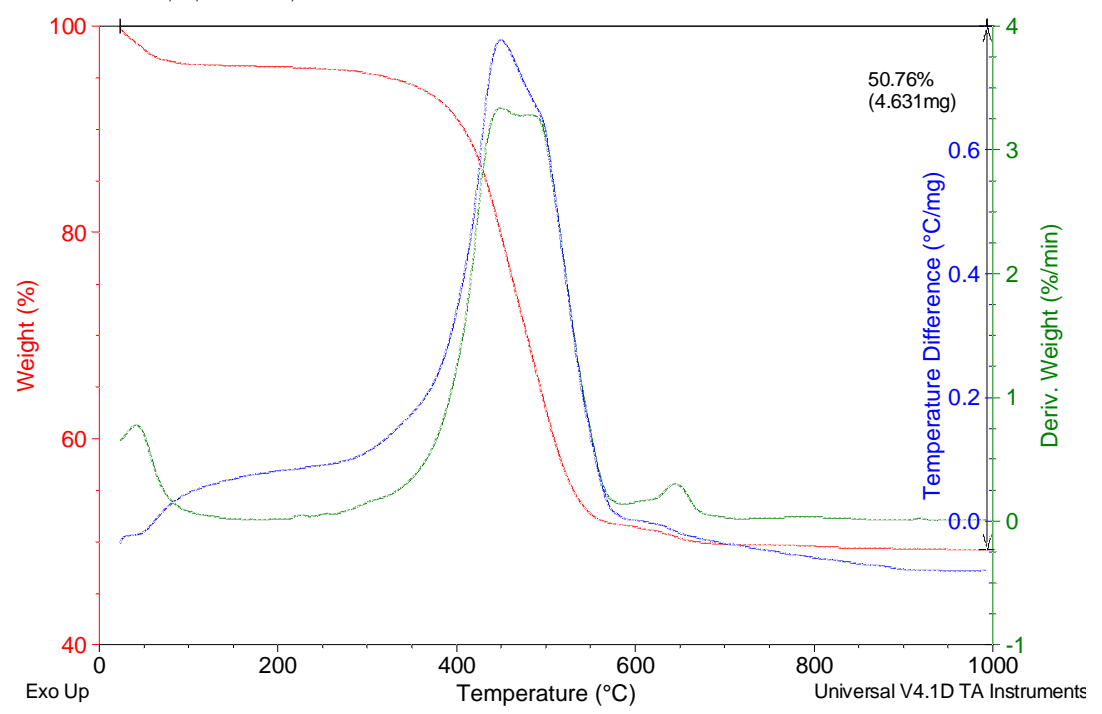

Figura 18 - amostra 7, (carvão ativado genérico $83 \%$ ), queimada a $350^{\circ} \mathrm{C}$ por $30 \mathrm{~min}$. 


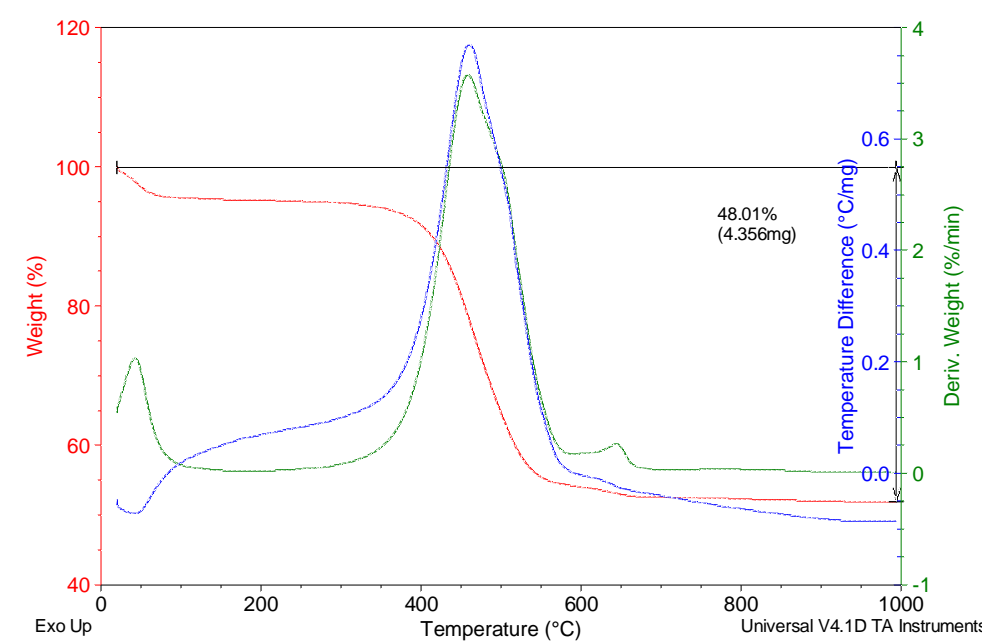

Figura 19 - amostra 10 (carvão ativado genérico 83\%), queimada a $500^{\circ} \mathrm{C}$ por $30 \mathrm{~min}$.

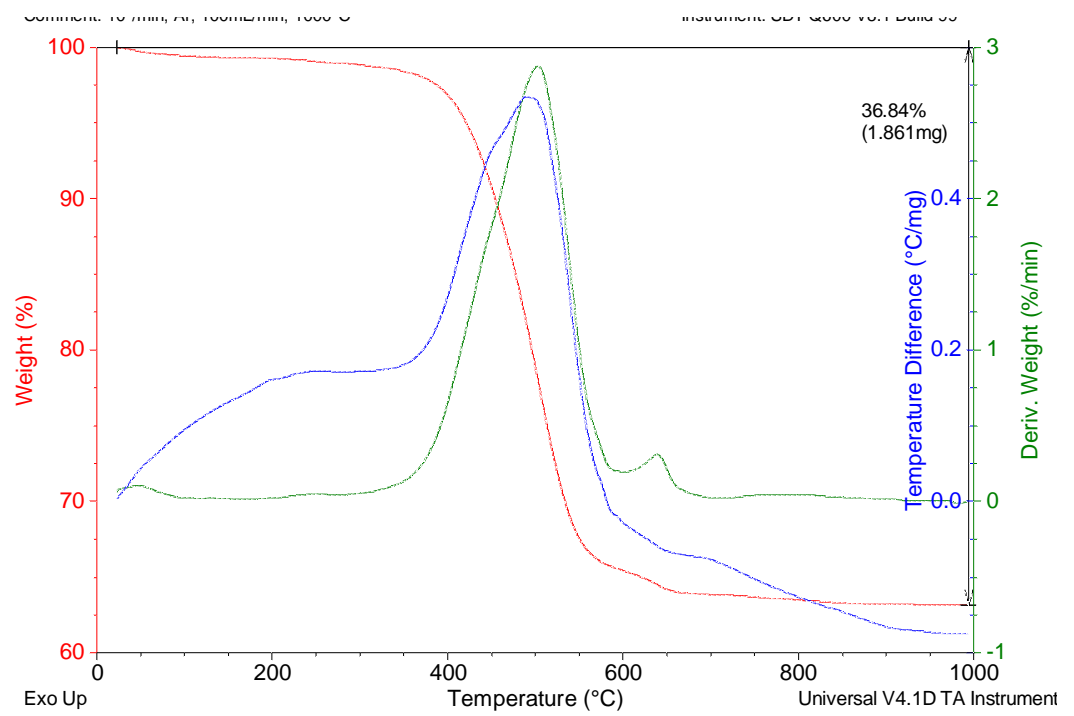

Figura 20 - amostra 14 (carvão ativado genérico 83\%), queimada a $750^{\circ} \mathrm{C}$ por 30 min.

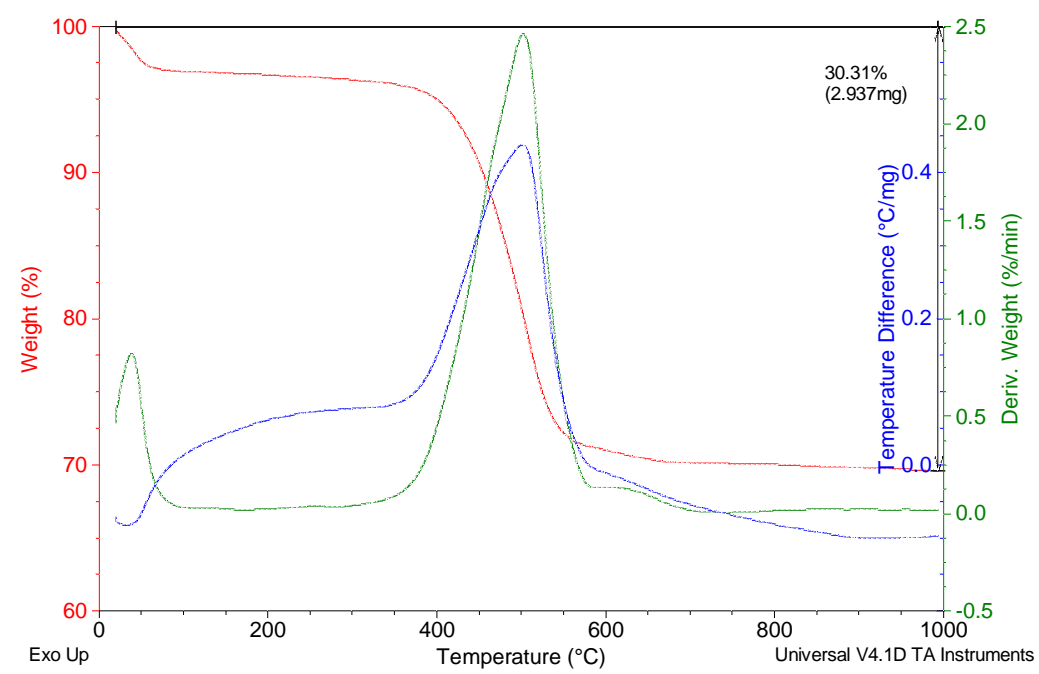

Figura 21 - amostra 18 (carvão ativado genérico 83\%), queimada a $900^{\circ} \mathrm{C}$ por $30 \mathrm{~min}$. 
Supondo-se que as amostras perderam 5\% de água de umidade e 5\% de água de desidroxilação, a amostra 3 (seca a $110^{\circ} \mathrm{C}$ ), continha $40 \%$ de matéria orgânica. A amostra 5 (queimada a 350) continha $41 \%$ de matéria orgânica. A amostra 10 (queimada a 500) continha $38 \%$ de matéria orgânica. A amostra 14 (queimada a 700) continha $27 \%$ de matéria orgânica. A amostra 18 (queimada a 900) continha $20 \%$ de matéria orgânica. Observa-se, pelos picos da derivada TG que a maior parte da queima do material carbonoso ocorre entre $300^{\circ} \mathrm{C}$ e $600^{\circ} \mathrm{C}$. Figuras 15 a 19.

\subsection{4 - Microscopia Eletrônica de Varredura}

São apresentadas as micrografias dos ensaios de Microscopia Eletrônica de Varredura (MEV) da argila chocolate, dos nanocompósitos de argila chocolate com amido de milho, sacarose e carvão ativado em pó (CAP).

\subsubsection{Argila Chocolate}

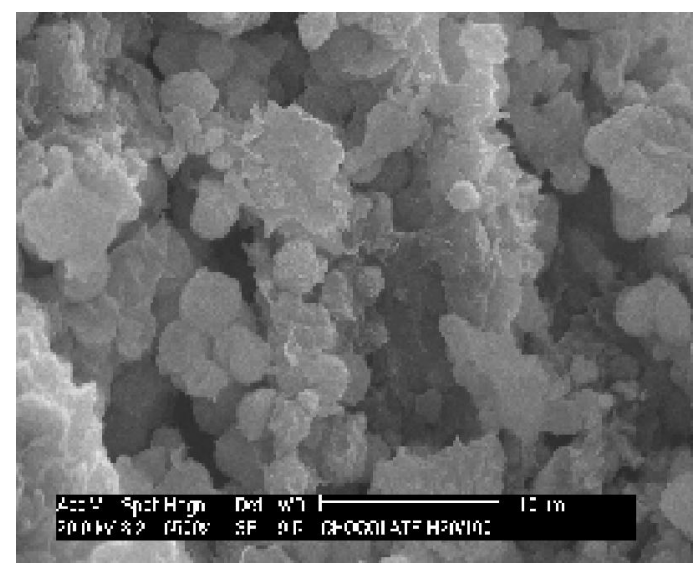

Figura 22 - micrografia da argila chocolate, seca a $60^{\circ} \mathrm{C}$ por 24 horas.

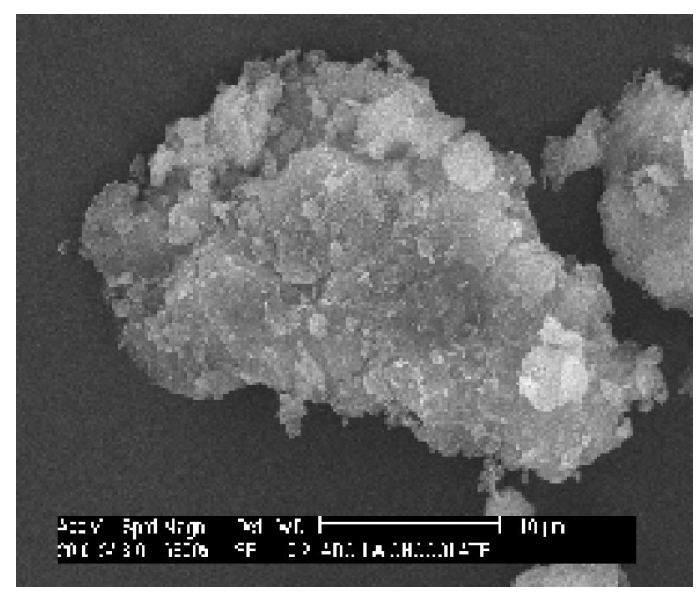


Figura 23 - micrografia da argila chocolate, seca a $100^{\circ} \mathrm{C}$ por 24 horas.

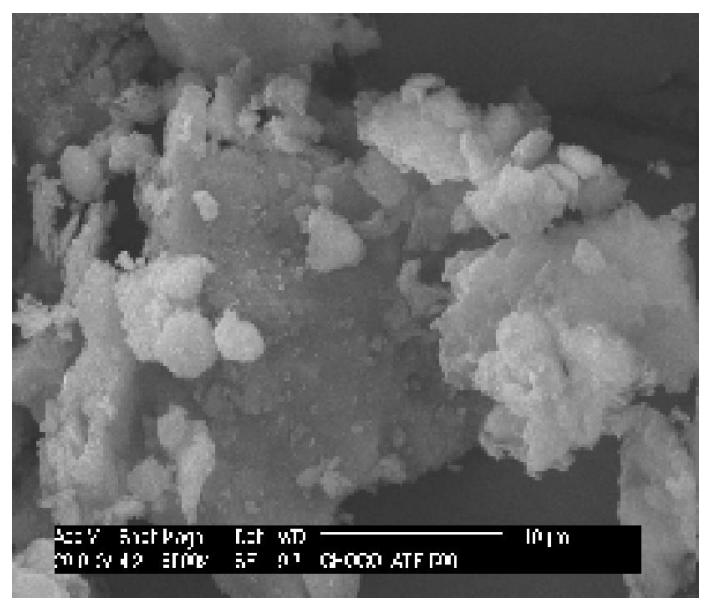

Figura 24 - micrografia da argila chocolate, queimada a $500^{\circ} \mathrm{C}$.

C:Whlunos PMȚNelmałcHoco.spc

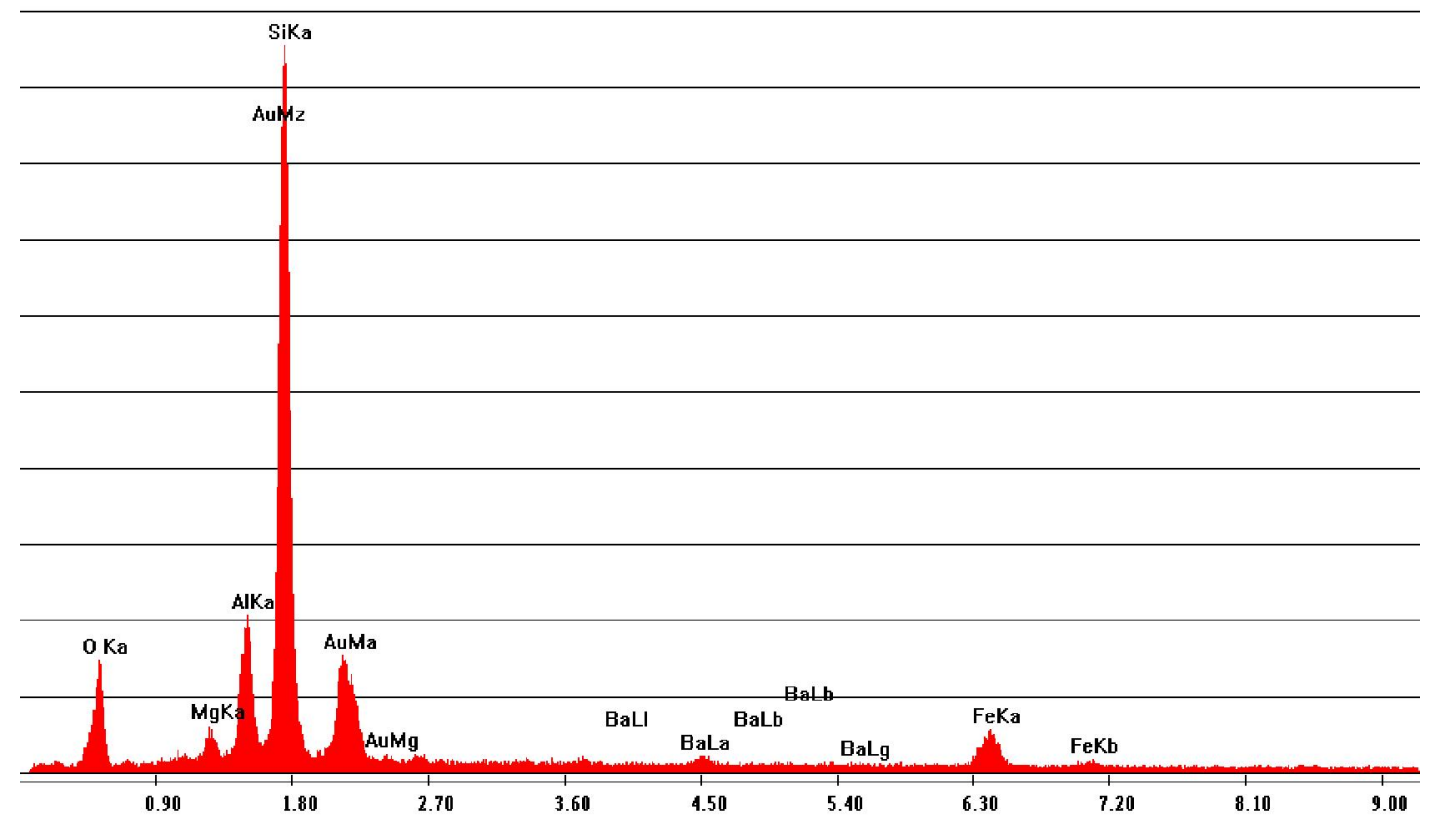

Figura 25 - difratograma de EDS da argila chocolate, natural, queimada a $500^{\circ} \mathrm{C}$.

4.1.4.2 - Nanocompósitos de argila chocolate com amido de milho 


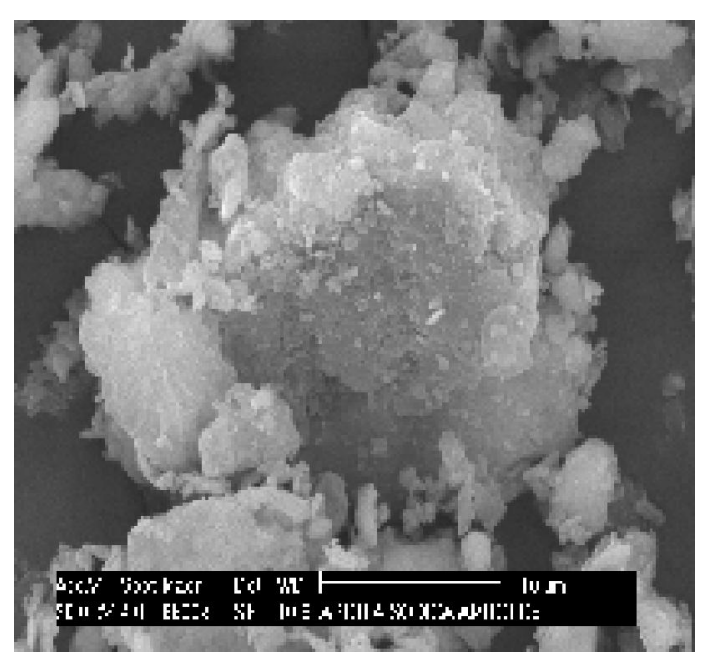

Figura 26 - micrografia do nanocompósito argila/amido de milho - amostra D-5 (10\% de amido em relação à massa de argila, queimada a $500^{\circ} \mathrm{C}, 30 \mathrm{~min}, 10^{\circ} / \mathrm{min}$.)

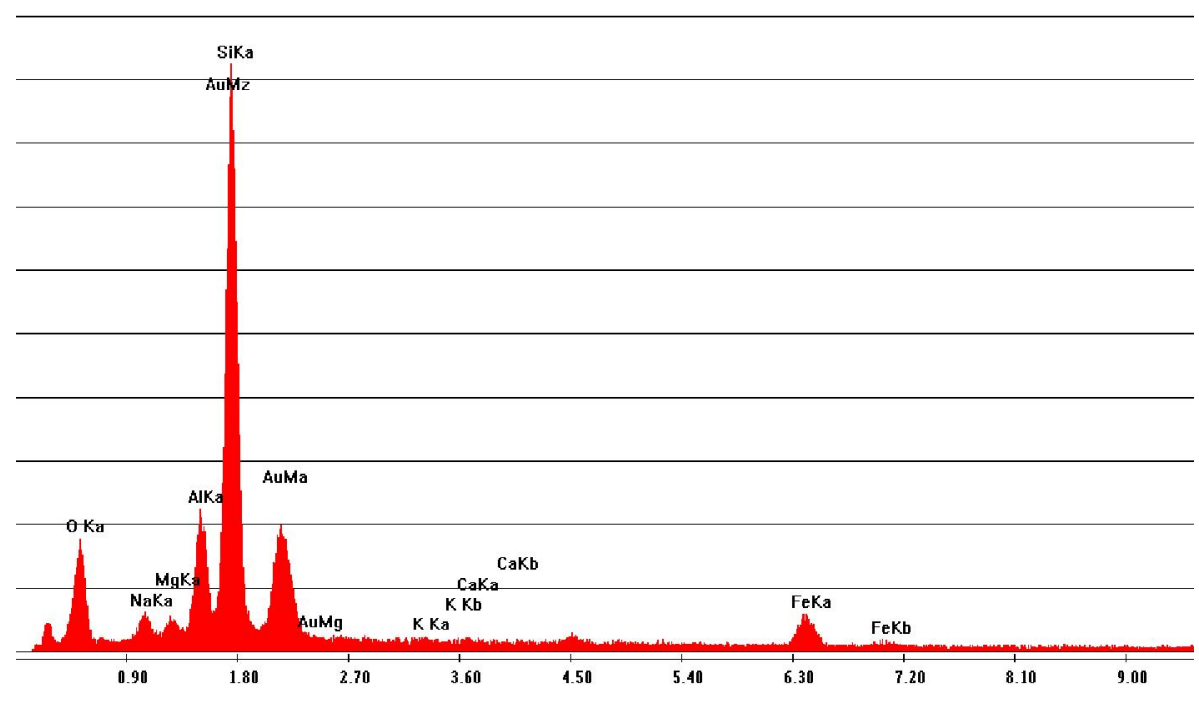

Figura 27 - difratograma de EDS do nanocompósito argila chocolate/amido de milho - amostra D-5 (10\% de amido em relação à massa de argila), queimada a $500^{\circ} \mathrm{C}$ por $30 \mathrm{~min}$. 


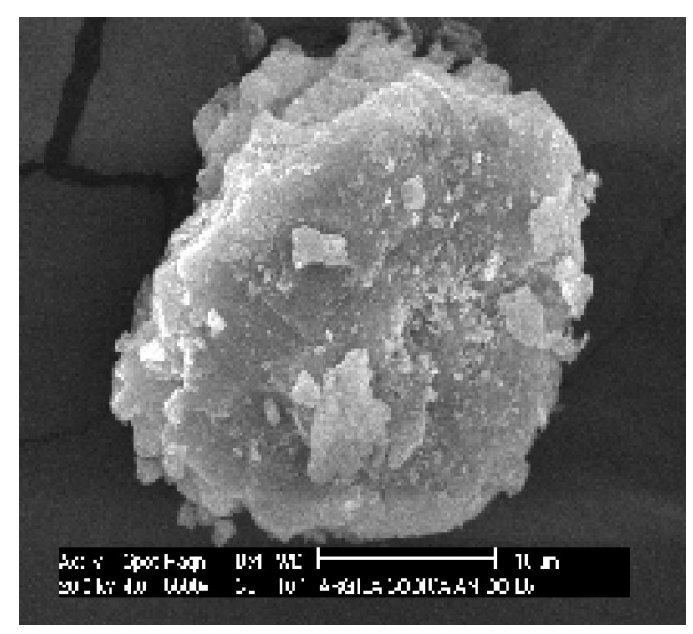

Figura 28 - micrografia do nanocompósito argila/amido de milho - amostra E-5 (20\% de amido em relação à massa de argila, queimada a $500^{\circ} \mathrm{C}, 30 \mathrm{~min}, 10^{\circ} / \mathrm{min}$.).

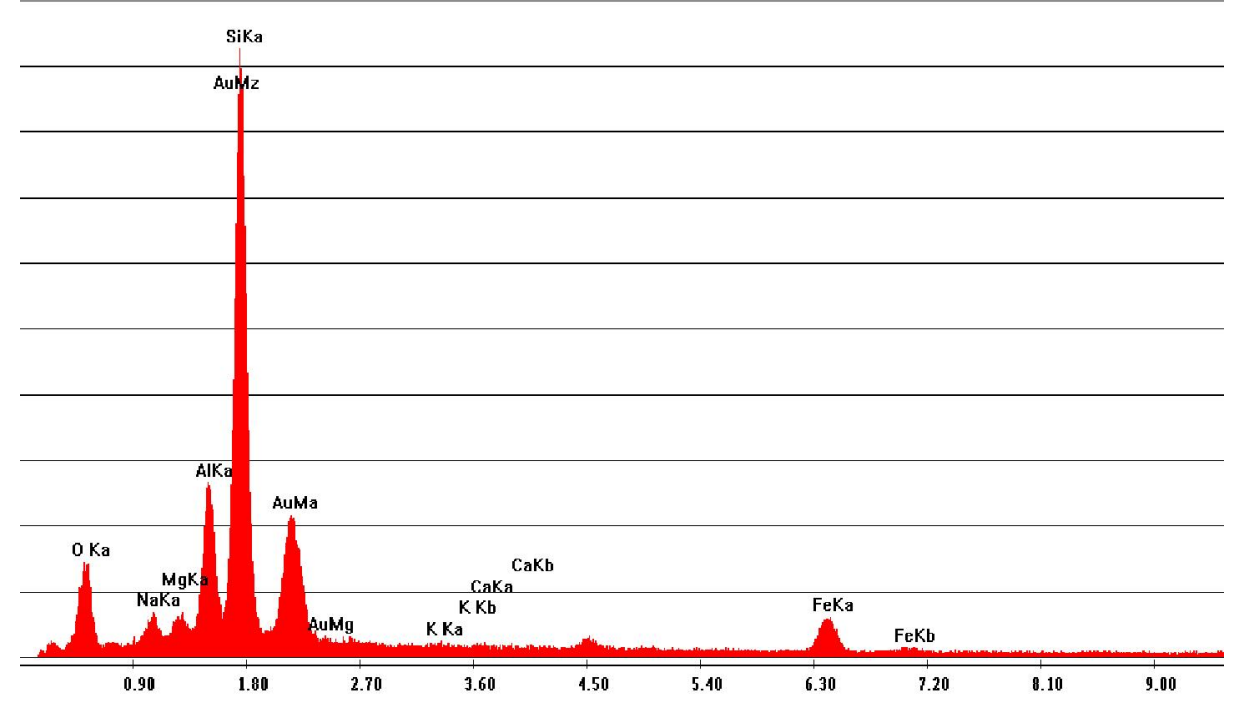

Figura 29 - difratograma de EDS do nanocompósito argila chocolate/amido de milho - amostra E-5 (20\% de amido em relação à massa de argila), queimada a $500^{\circ} \mathrm{C}$ por $30 \mathrm{~min}$.

\subsubsection{3 - N N Nanocompósitos de argila chocolate com sacarose}




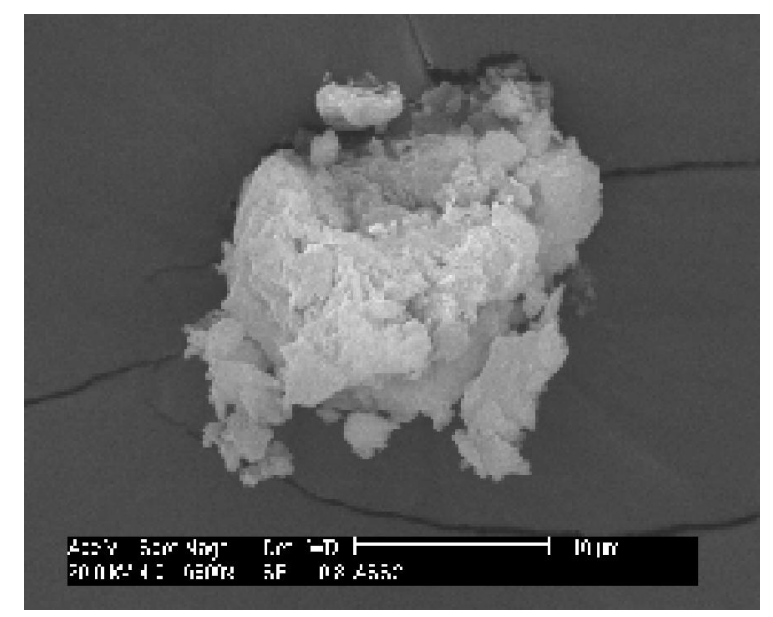

Figura 30 - micrografia do nanocompósito argila/sacarose - amostra ASS- B (5,0\% de sacarose em relação à massa de argila, queimada a $500^{\circ} \mathrm{C}, 30 \mathrm{~min}, 10^{\circ} / \mathrm{min}$.).

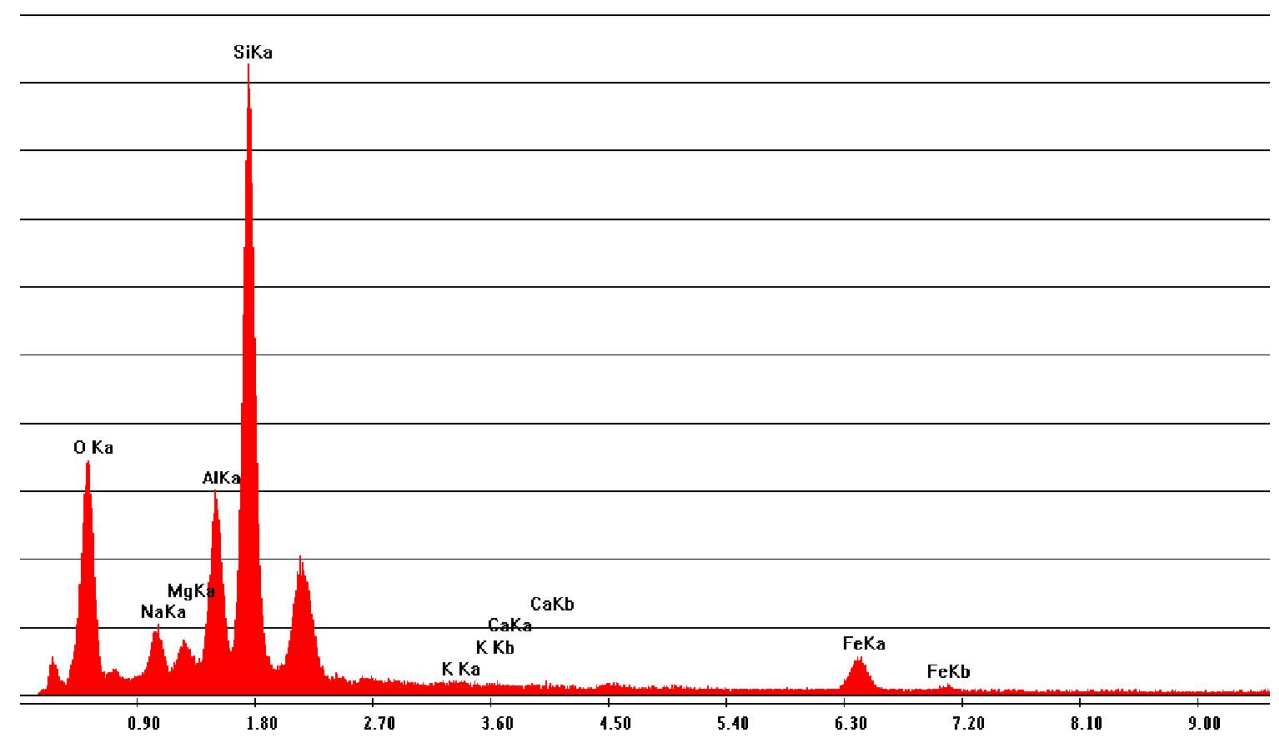

Figura 31 - difratograma de DRX do nanocompósito argila chocolate/sacarose amostra ASS-B (5\% de sacarose em relação à massa de argila), queimada a $500^{\circ} \mathrm{C}$ por $30 \mathrm{~min}$. 


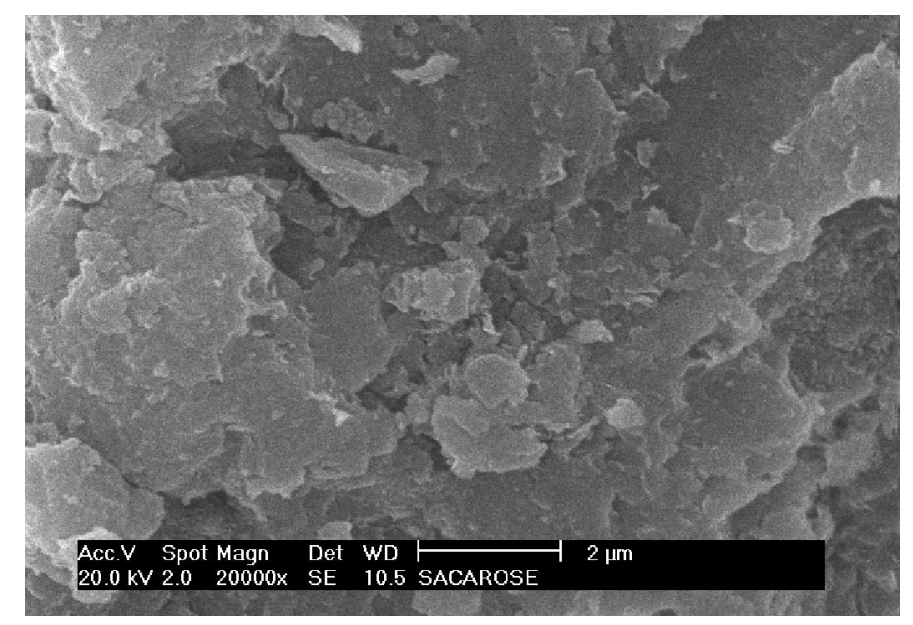

Figura 32 - micrografia do nanocompósito argila/sacarose - amostra ASS- D (10\% de sacarose em relação à massa de argila, queimada a $500^{\circ} \mathrm{C}, 30 \mathrm{~min}, 10^{\circ} / \mathrm{min}$.).

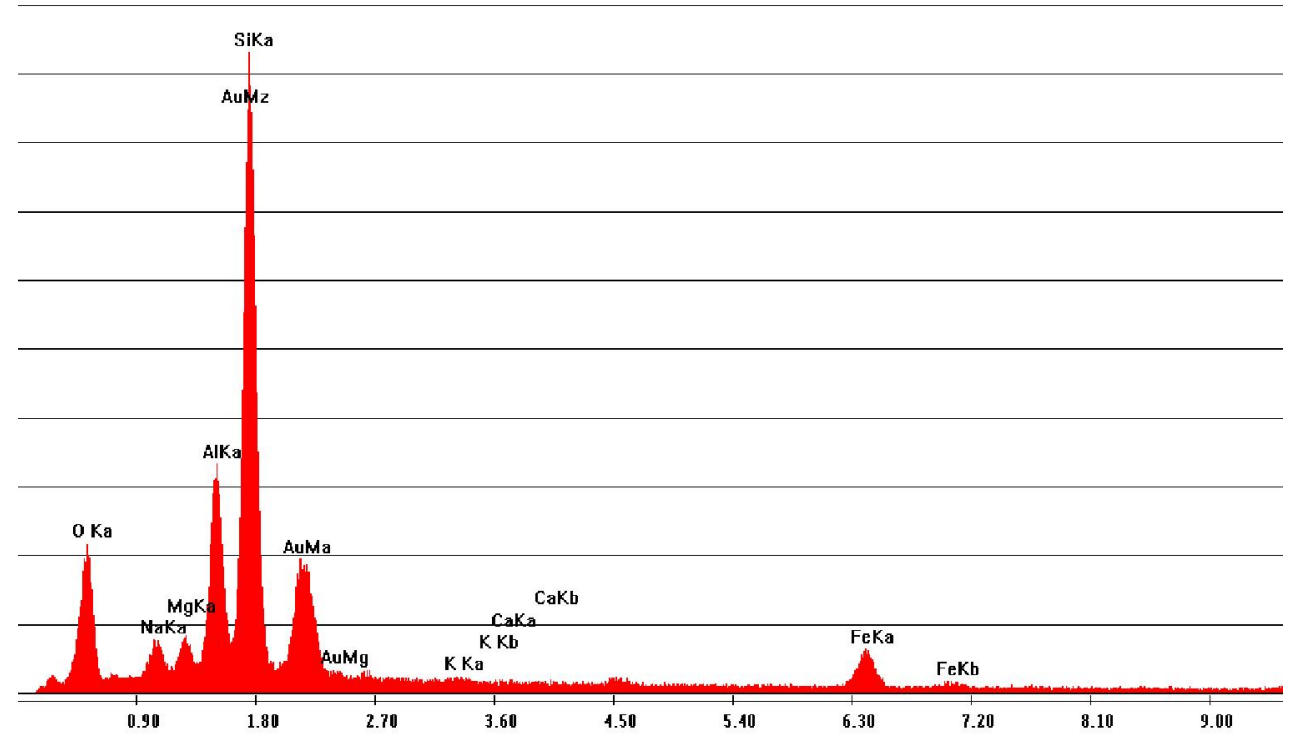

Figura 33 - difratograma de EDS do nanocompósito argila chocolate/sacarose - amostra ASS-D $\left(10 \%\right.$ de sacarose em relação à massa de argila), queimada a $500^{\circ} \mathrm{C}$ por $30 \mathrm{~min}$.

\subsubsection{4 - $\quad$ - Nanocompósitos de argila chocolate com carvão ativado}




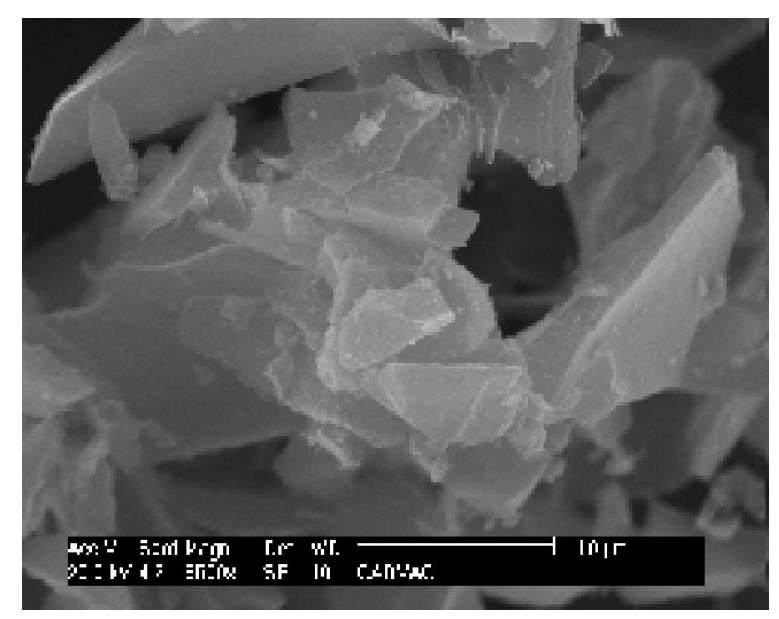

Figura 34 - micrografia do carvão ativado em pó, marca VETEC.

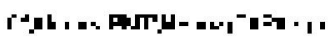

L:tri.,

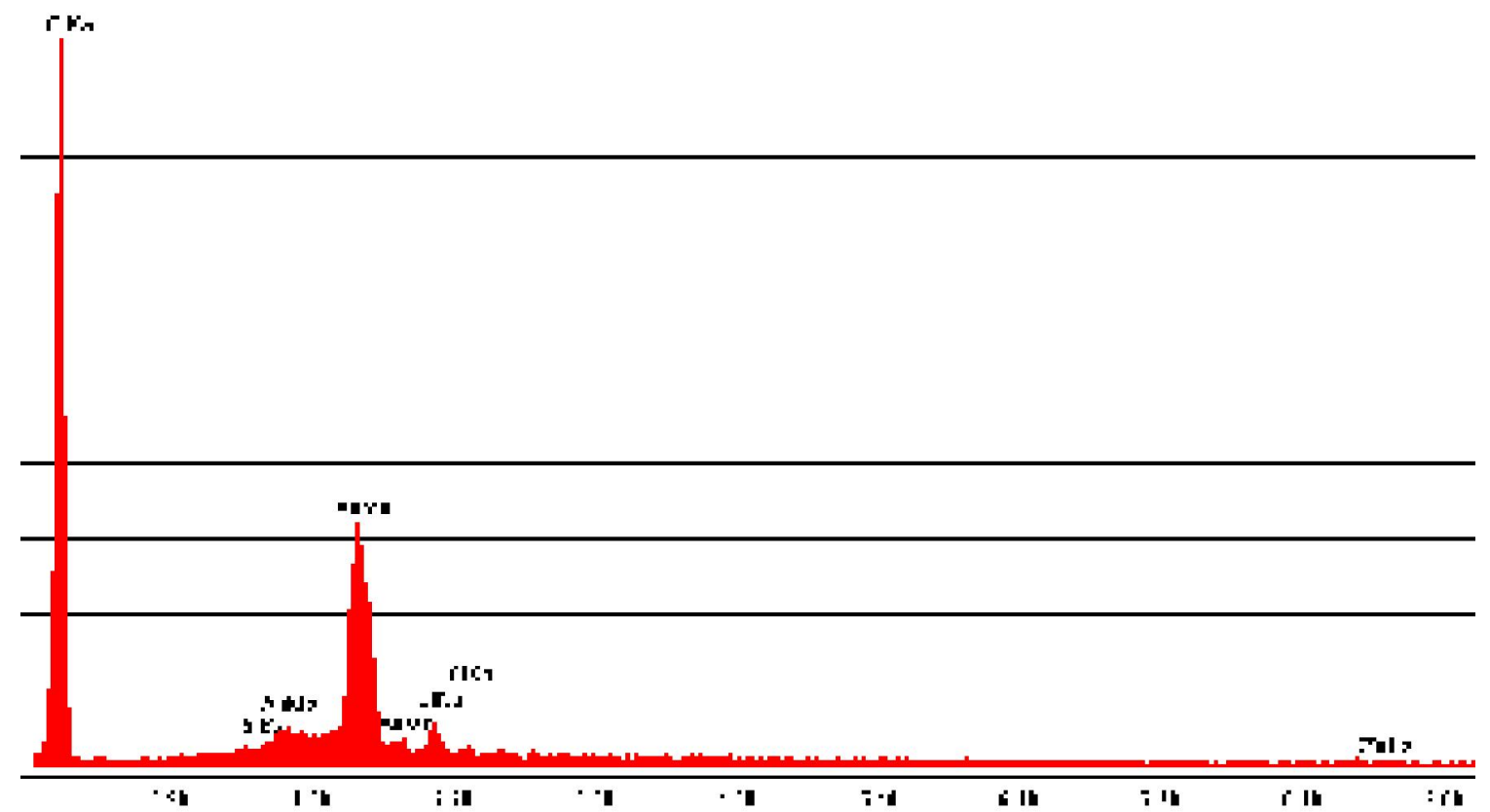

Figura 35 - difratograma de EDS do carvão ativado em pó, marca VETEC. 


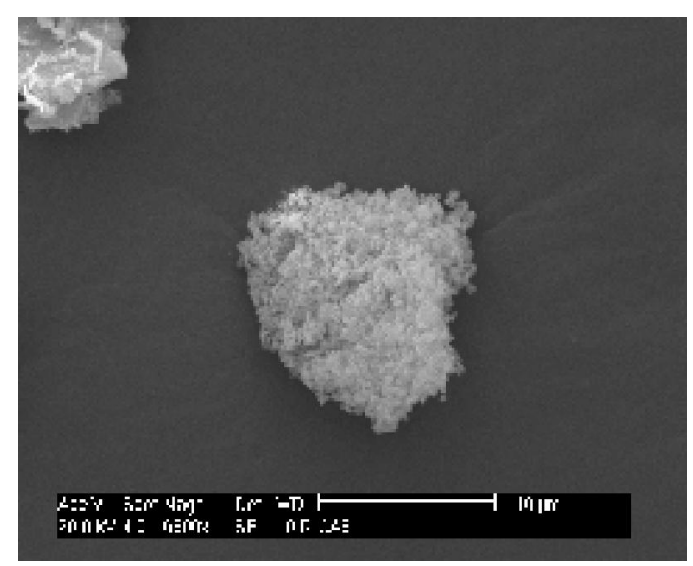

Figura 36 - micrografia do compósito argila/carvão ativado em pó - amostra 8 (83\% de carvão ativado em pó em relação à massa de argila, queimada a $350^{\circ} \mathrm{C}, 30 \mathrm{~min}$, $10 \%$ min.).

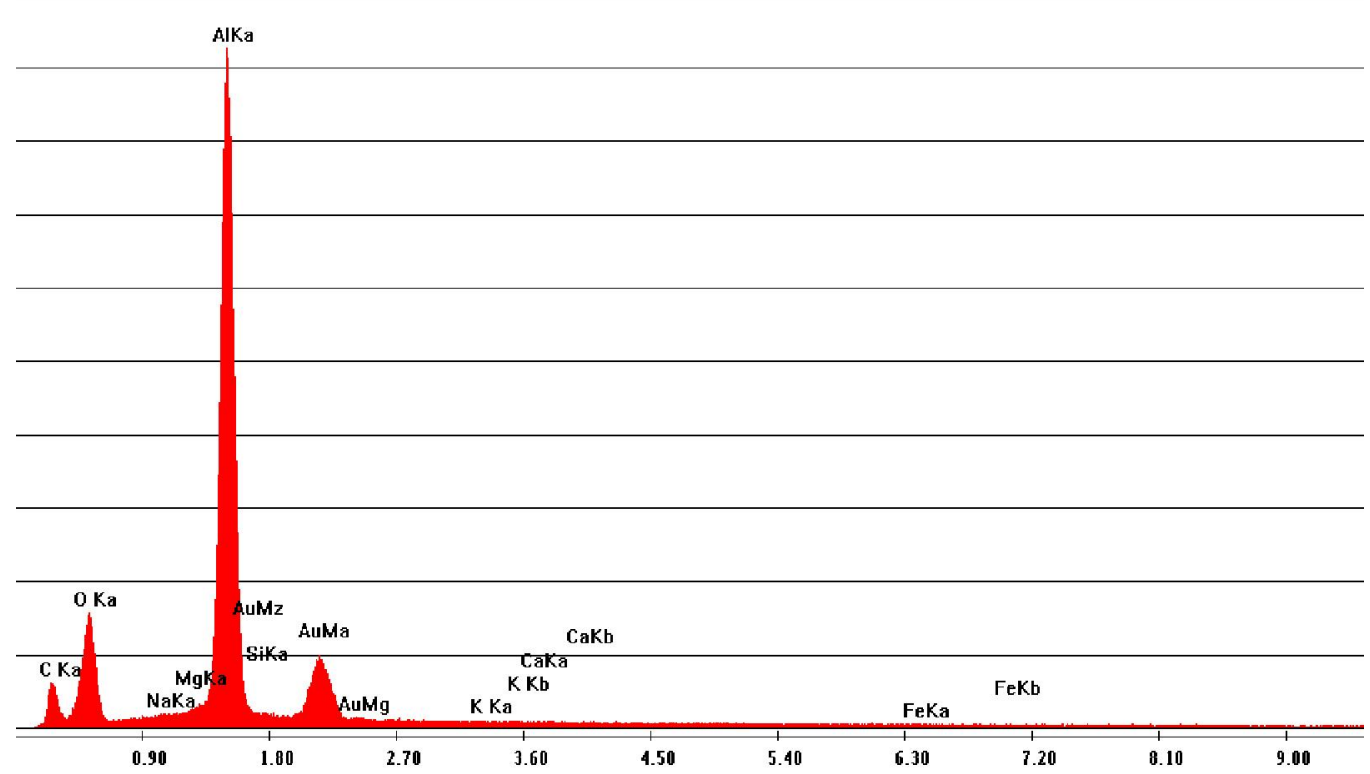

Figura 37 - difratograma de EDS do compósito argila chocolate/carvão ativado - amostra 8 (83\% de carvão ativado em relação à massa de argila), queimada a $350^{\circ} \mathrm{C}$ por $30 \mathrm{~min}$. 


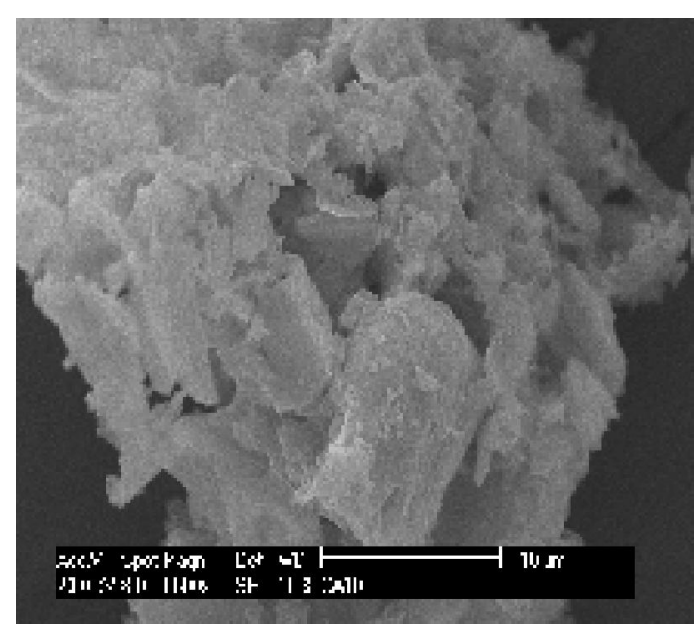

Figura 38 - micrografia do compósito argila/carvão ativado em pó - amostra 10 (83\% de carvão ativado em pó em relação à massa de argila, queimada a $500^{\circ} \mathrm{C}, 30 \mathrm{~min}$, $10 \%$ min.).

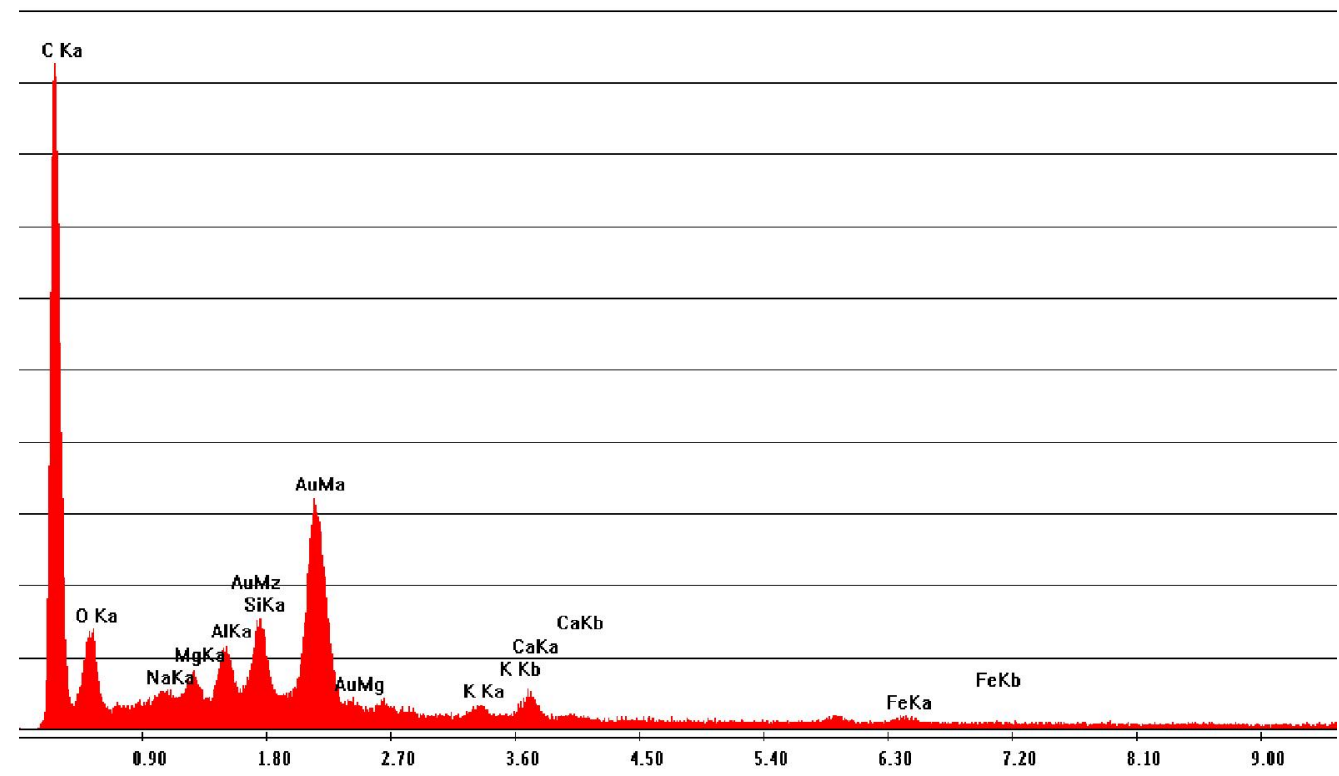

Figura 39 - difratograma de EDS do compósito argila chocolate/carvão ativado - amostra 10 (83\% de carvão ativado em relação à massa de argila), queimada a $500^{\circ} \mathrm{C}$ por $30 \mathrm{~min}$. 


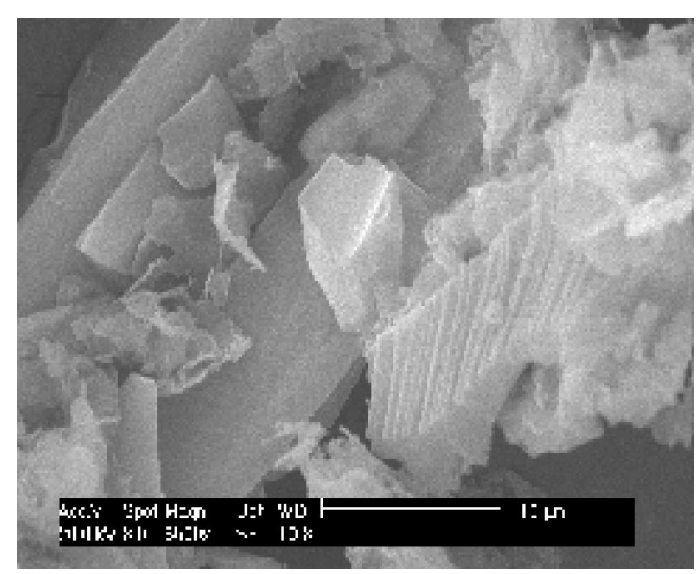

Figura 40 - micrografia do compósito argila/carvão ativado em pó - amostra 22 (75\% de carvão ativado em pó em relação à massa de argila, queimada a $500^{\circ} \mathrm{C}$, sem patamar, $10^{\circ} \mathrm{C} / \mathrm{min}$.).

F:|xx|\}USRIALUNOS|Nelmał020608\}22.spc

Label A:

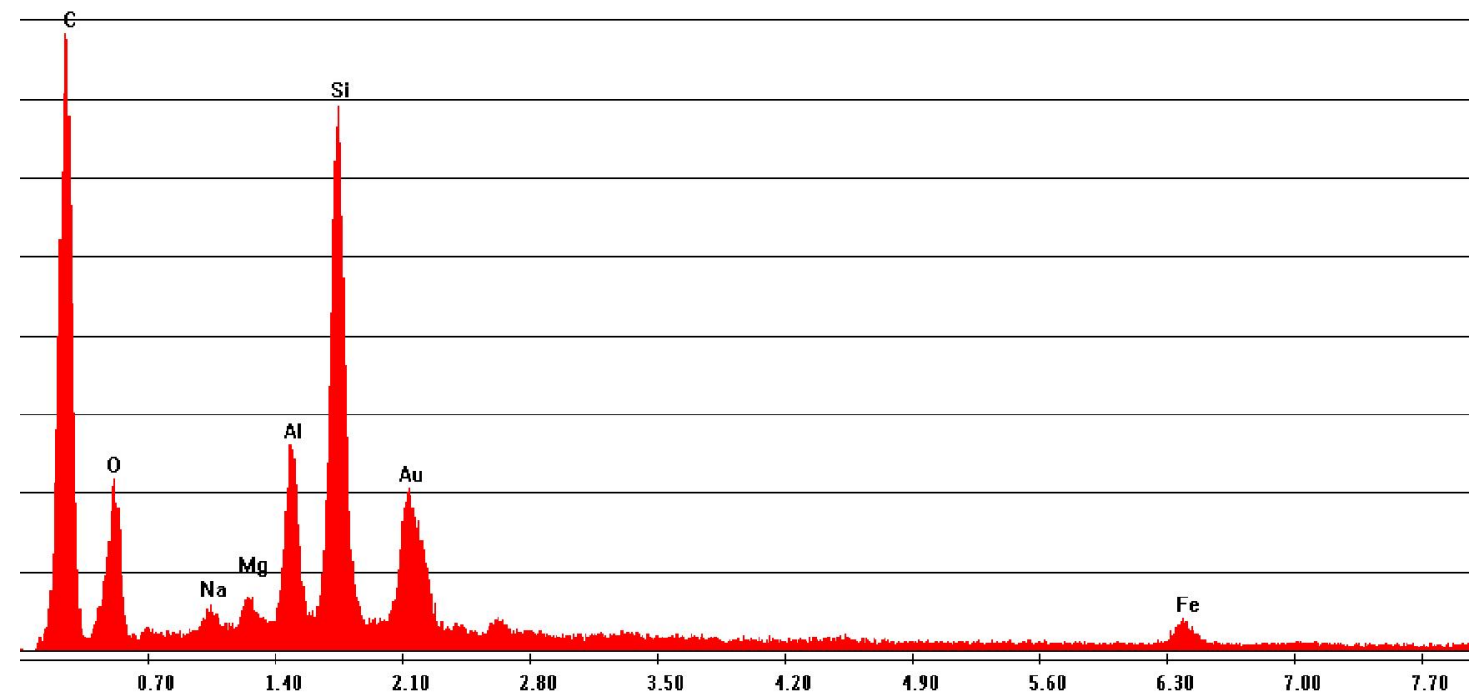

Figura 41 - difra togra ma de EDS do compósito argila/carvão ativado em pó amostra 22 (75\% de carvão ativado em pó em relação à massa de argila, queimada a $500^{\circ} \mathrm{C}$, sem patamar, $10^{\circ} \mathrm{C} / \mathrm{min}$.). 


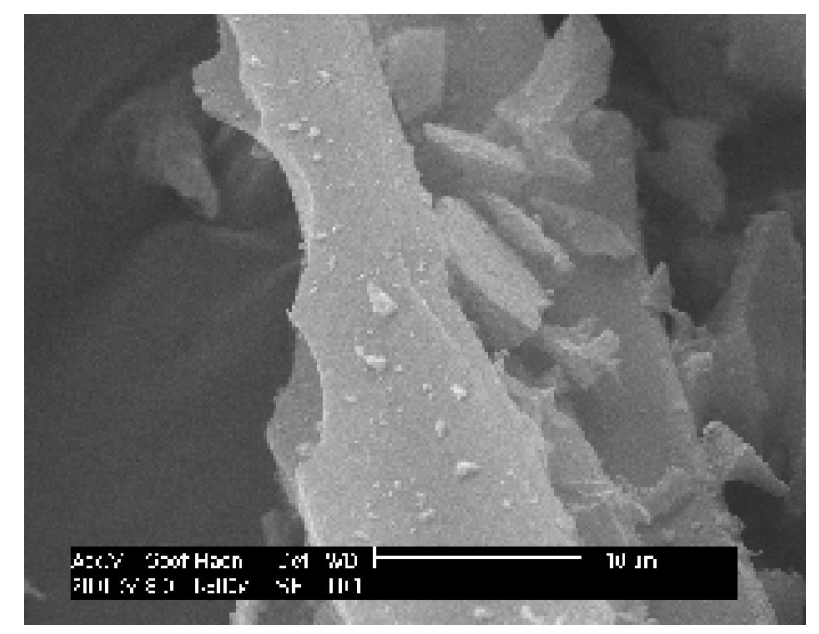

Figura 42 - micrografia do compósito argila/carvão ativado em pó - amostra 25 (75\% de carvão ativado em pó em relação à massa de argila, queimada a $750^{\circ} \mathrm{C}$, sem patamar, $10^{\circ} \mathrm{C} / \mathrm{min}$.).

F:|XIYUSRMLUNOSYNeIma\}020608\}25.spc

Label A:

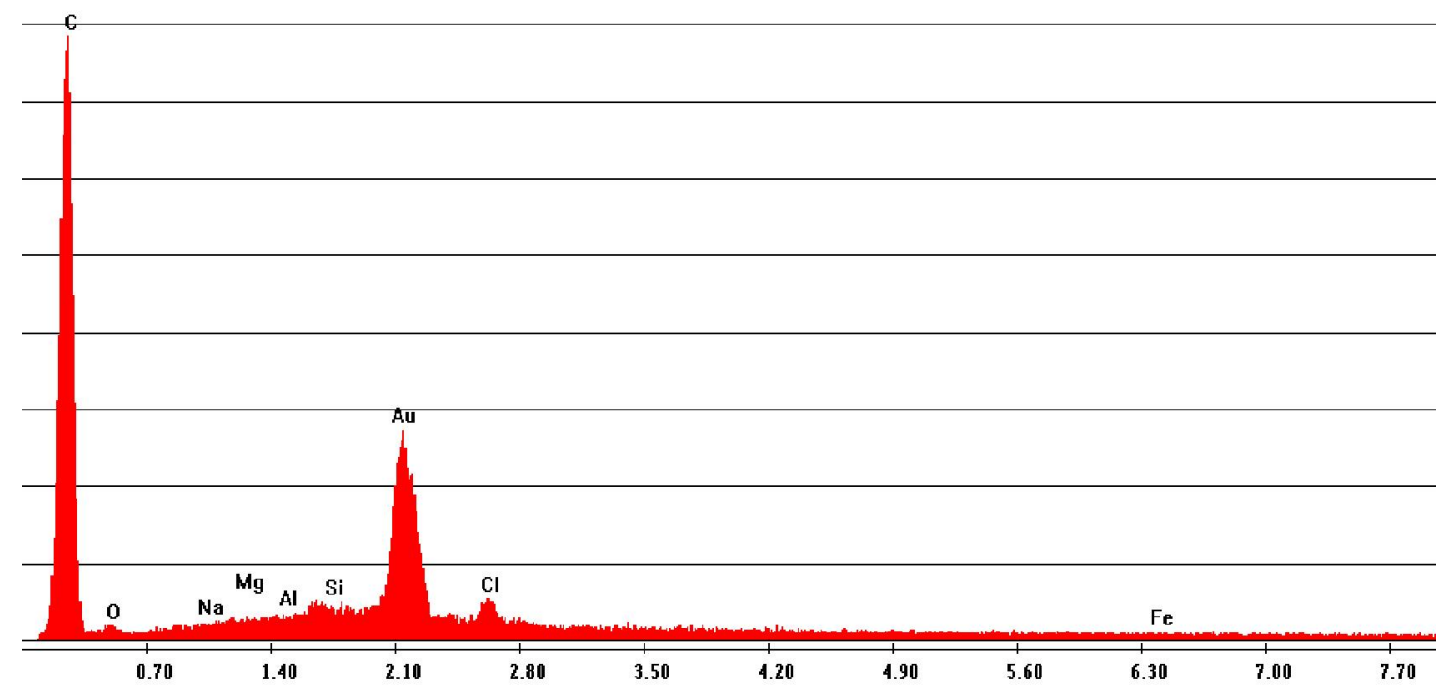

Figura 43 - difra togra ma de EDS do compósito argila/carvão ativado em pó amostra 25 (75\% de carvão ativado em pó em relação à massa de argila, queimada a $750^{\circ} \mathrm{C}$, sem patamar, $10^{\circ} \mathrm{C} / \mathrm{min}$.). 


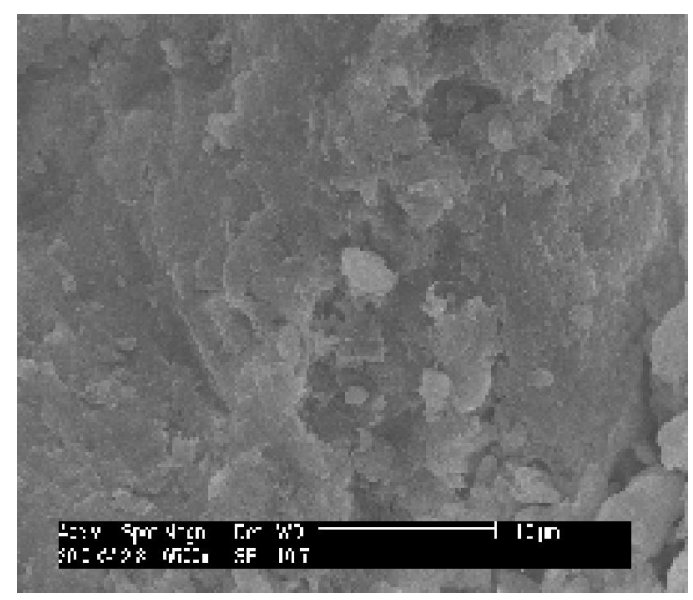

Figura 44 - micrografia do compósito argila/carvão ativado em pó - amostra 28 (75\% de carvão ativado em pó em relação à massa de argila, queimada a $900^{\circ} \mathrm{C}$, sem patamar, $10^{\circ} \mathrm{C} / \mathrm{min}$.).

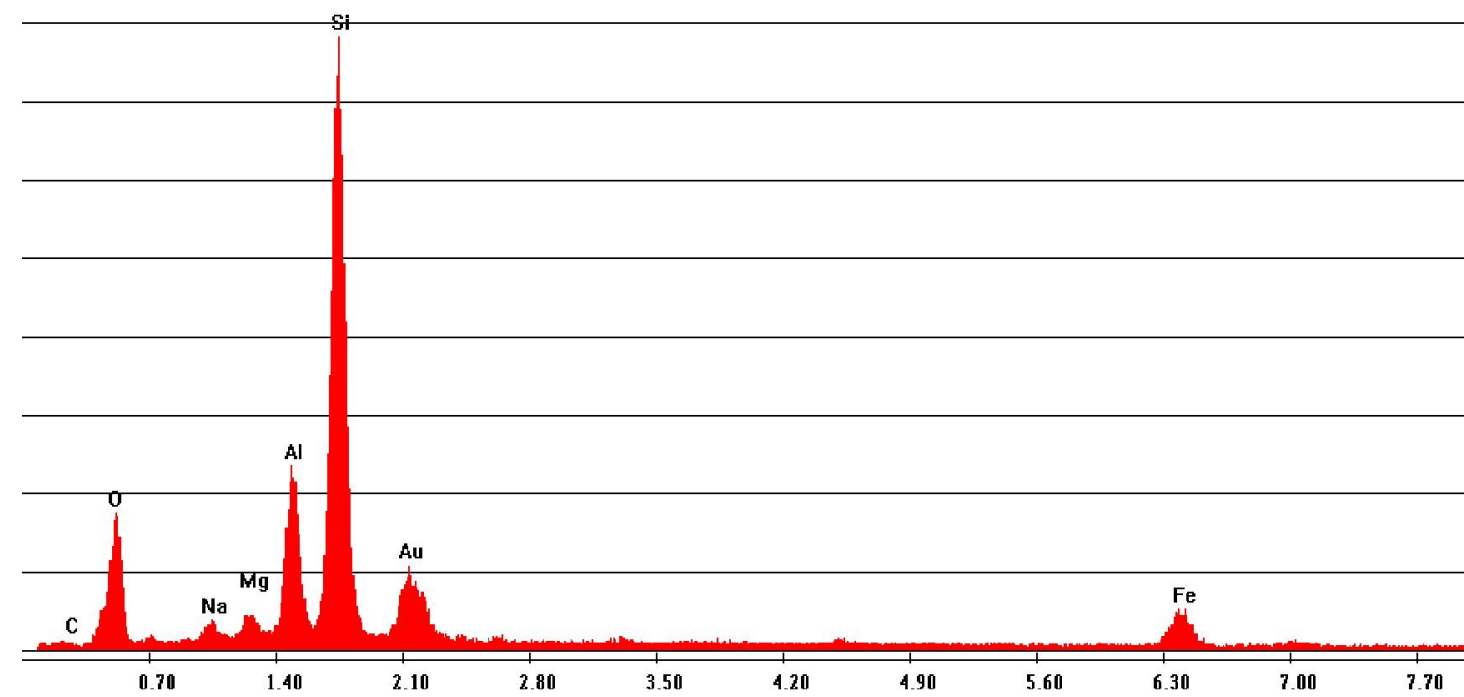

Figura 45 - difra togra ma de EDS do nanocompósito argila/carvão ativado em pó amostra 28 (75\% de carvão ativado em pó em relação à massa de argila, queimada a $900^{\circ} \mathrm{C}$, sem patamar, $10^{\circ} \mathrm{C} / \mathrm{min}$.).

Observa-se, em todas as micrografias (figuras 20 a 44), a morfologia lamelar típica dos argilominerais esmectíticos. Pressupõe-se dada a não observação de partículas de material carbonoso que o mesmo se distribui de forma homogênea sobre a superfície 
do argilomineral. Nos ensaios de EDS, observou-se, como era de se esperar, pela composição comun das bentonitas da Paraíba, a predominância de silício, oxigênio, sódio, cálcio, potássio e ferro. 


\subsection{5 - Sorção (ad/absorção) de Azul de Metileno (AM)}

4.1.5.1 - Nanocompósitos de argila chocolate com amido de milho

Tabela 19 - Resultados dos ensaios de adsorção de azul de metileno pela argila chocolate.

\begin{tabular}{ccc}
\hline Código & $\mathrm{T}\left({ }^{\circ} \mathrm{C} / 24 \mathrm{~h}\right)$ & Adsorção AM (mg AM/g amostra) \\
\hline Argila chocolate & 60 & 120 \\
\hline Argila chocolate & 110 & 12 \\
\hline
\end{tabular}

Tabela 20 - Resultados dos ensaios de adsorção de azul de metileno, referentes ao procedimento $\mathrm{A}$ (amido em gel).

\begin{tabular}{cccc} 
Código & $\%$ amido & $\mathrm{T}\left({ }^{\circ} \mathrm{C} / 30 \mathrm{~min}\right)$ & Adsorção AM (mg AM/g amostra) \\
\hline B - 3 & - & 350 & 20 \\
\hline B - 5 & & 500 & 20 \\
\hline C - 3 & 5,0 & 350 & $<20$ \\
\hline C - 5 & & 500 & $<20$ \\
\hline D - 3 & 10,0 & 350 & $<20$ \\
\hline D - 5 & & 500 & $\cong 20 \mathrm{mg}$ \\
\hline E - 3 & 20,0 & 350 & $<20$ \\
\hline E - 5 & & 500 & $32 \mathrm{mg}$ \\
\hline F - 3 & 30,0 & 350 & $<20$ \\
\hline F - 5 & & 500 & $<20$ \\
\hline K - 3 & 100,0 & 350 & 20 \\
\hline K - 5 & & 500 & 20
\end{tabular}


Tabela 21 - Resultados dos ensaios de adsorção de azul de metileno, referentes ao procedimento $B$ (amido em pó).

\begin{tabular}{cccc}
\hline Código & $\%$ amido & $\mathrm{T}\left({ }^{\circ} \mathrm{C} / 30 \mathrm{~min}\right)$ & $\begin{array}{c}\text { Adsorção AM }(\mathrm{mg} \mathrm{AM} / \mathrm{g} \\
\text { amostra })\end{array}$ \\
\hline ASA - 2 & 20,0 & 350 & 200 \\
\hline ASA - 2 & & 500 & 200 \\
\hline ASA - 5 & 20,0 & 350 & 200 \\
\hline ASA - 5 & & 500 & 200 \\
\hline
\end{tabular}

Para o procedimento A obtiveram-se baixos valores de sorção de azul de metileno, principalmente quando comparados com o da argila natural seca a 60C.

Comparando-se os valores de adsorção obtidos para as amostras referentes ao procedimento $B$ (amido em pó), $200 \mathrm{mg} \mathrm{AM/g}$ amostra) percebese que houve uma melhora significativa para a adsorção do Azul de Metileno. É necessário salientar as diferenças entre os dois procedimentos. Além da temperatura de secagem da argila, mudou-se também a maneira de se misturar o amido na dispersão. No primeiro, misturou-se o amido em gel, isto é, o grânulo do amido já estava inchado, enquanto no segundo o amido inchou durante a adição na dispersão aquosa. Assim é possível que o menor volume da molécula de amido (pó) favoreça a sua incorporação na argila e este seja um dos fatores que contribui para a melhor adsorção do corante.

É importante salientar, assim, o efeito deletério que a temperatura de secagem pode ter causado na capacidade de sorção dos complexos argila/material carbonoso obtidos pelo Procedimento A. 


\subsubsection{2 - $\quad$ Nanocompósitos de argila chocolate com sacarose}

Tabela 22 - Resultados dos ensaios de adsorção de azul de metileno pelos nanocompósitos argila chocolate/sacarose.

\begin{tabular}{|c|c|c|c|}
\hline Código & $\%$ sacarose & $\begin{array}{c}\mathrm{T}\left({ }^{\circ} \mathrm{C} / 30\right. \\
\min )\end{array}$ & adsorção AM (mg AM/g amostra) \\
\hline \multirow[t]{2}{*}{ ASS - A } & 2,5 & 350 & $<20$ \\
\hline & & 500 & $<20$ \\
\hline \multirow[t]{2}{*}{ ASS - B } & 5,0 & 350 & $<20$ \\
\hline & & 500 & $<20$ \\
\hline \multirow[t]{2}{*}{ ASS - C } & 7,5 & 350 & $<20$ \\
\hline & & 500 & $<20$ \\
\hline \multirow[t]{2}{*}{ ASS - D } & 10,0 & 350 & $<20$ \\
\hline & & 500 & $<20$ \\
\hline \multirow[t]{2}{*}{ ASS - E } & 20,0 & 350 & 200 \\
\hline & & 500 & 200 \\
\hline
\end{tabular}

Para o procedimento A - amostras ASS-A, ASS-B, ASS-C, ASS-D formadas por argila chocolate seca a $110^{\circ} \mathrm{C}$ e sacarose apresentaram baixos valores de adsorção, independente da porcentagem de sacarose em relação à argila. Para o preparo destas amostras utilizou-se a argila chocolate seca a $110^{\circ} \mathrm{C}$ e a sacarose estava na forma de xarope aquoso. Ao se comparar estes resultados com os obtidos pelas amostras de argila e amido de milho - obtidas nas mesmas condições, percebe-se que os valores de adsorção foram próximos.

A amostra ASS-E foi obtida a partir da argila chocolate seca a $60^{\circ} \mathrm{C}$ e a sacarose foi adicionada na dispersão na forma natural. Assim como nos compósitos formados entre a argila chocolate e o amido, a adsorção foi significativamente maior. Desta maneira, acredita-se que tanto a temperatura 
de secagem da argila chocolate como a forma de adição do material carbonoso sejam fatores preponderantes para a adsorção do corante azul de metileno.

\subsubsection{3 - C Compósitos de argila chocolate com carvão ativado}

Tabela 23 - Resultados dos ensaios de adsorção de azul de metileno por carvão ativado.

\begin{tabular}{cc}
\hline Amostras & Adsorção (mg de AM/g amostra) \\
\hline CAPV & 400 \\
\hline CAP & 20 \\
\hline
\end{tabular}

O carvão ativado PA (Vetec) apresentou uma alta capacidade de sorção de azul de metileno (400 mg/g carvão), substancialmente maior ao do carvão genérico $(20 \mathrm{mg} / \mathrm{g})$. Os complexos preparados com o carvão genérico (tabela 23) apresentaram também baixos valores de sorção de azul de metileno (40mg/g). 
Tabela 24 - Resultados dos ensaios de adsorção de azul de metileno pelos compósitos argila chocolate/carvão ativado genérico, procedimento $A$.

\begin{tabular}{|c|c|c|c|}
\hline \multirow[t]{2}{*}{ Temperatura $(\stackrel{\circ}{ } \mathrm{C})$} & \multirow[t]{2}{*}{ Amostras } & \multicolumn{2}{|c|}{ Adsorção (mg de AM/g amostra) } \\
\hline & & $t=24 h$ & $t=48 h$ \\
\hline \multirow[t]{2}{*}{110} & 3 & 40 & 40 \\
\hline & 4 & 40 & 40 \\
\hline \multirow[t]{3}{*}{350} & 7 & 40 & 40 \\
\hline & 8 & 40 & 40 \\
\hline & 10 & 32 & 40 \\
\hline \multirow[t]{3}{*}{500} & 11 & 32 & 40 \\
\hline & 12 & 32 & 40 \\
\hline & 14 & 20 & 40 \\
\hline \multirow[t]{3}{*}{750} & 15 & 20 & 40 \\
\hline & 16 & 20 & 40 \\
\hline & 18 & 20 & 40 \\
\hline \multirow[t]{2}{*}{900} & 19 & 20 & 40 \\
\hline & 20 & 20 & 40 \\
\hline
\end{tabular}


Tabela 25 - Resultados dos ensaios de adsorção de azul de metileno pelos compósitos argila chocolate/carvão ativado Vetec, procedimento B.

\begin{tabular}{|c|c|c|}
\hline Temperatura & Amostras & $\begin{array}{c}\text { Adsorção (mg de AM/g } \\
\text { amostra) }\end{array}$ \\
\hline \multirow{3}{*}{ 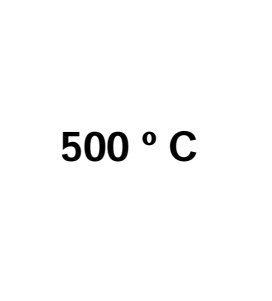 } & 21 & 400 \\
\hline & 22 & 400 \\
\hline & 23 & 400 \\
\hline \multirow{3}{*}{$750 \cong \mathrm{C}$} & 24 & 400 \\
\hline & 25 & 400 \\
\hline & 26 & 400 \\
\hline \multirow{3}{*}{ 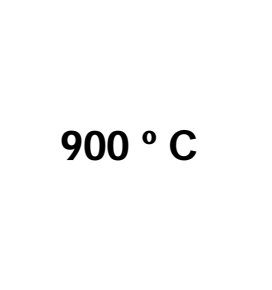 } & 27 & 400 \\
\hline & 28 & 400 \\
\hline & 29 & 400 \\
\hline
\end{tabular}

Analisando-se os valores da adsorção do azul de metileno pelos compósitos argila chocolate/carvão ativado genérico e compósitos argila chocolate/carvão ativado Vetec, percebe-se a influência do tipo de carvão utilizado no preparo dos materiais. A diferença é muito grande. Deve-se observar que os compósitos que apresentam os maiores resultados de adsorção (21 a 29), a porcentagem de carvão ativado foi menor (83\% com o genérico e $75 \%$ no carvão PA). Este fato pode ser indicativo de que a temperatura de secagem da argila pode ser outro fator que contribua para a melhor adsorção do corante azul de metileno.

Comparando-se os resultados de sorção obtidos para os complexos argila/material carbonoso, especificamente para o procedimento $\mathrm{B}$, deste trabalho - tanto do amido $\left(200 \mathrm{~m}^{2} / \mathrm{g}\right)$, quanto da sacarose $\left(200 \mathrm{~m}^{2} / \mathrm{g}\right)$ e do 
carvão ativado Vetec $\left(400 \mathrm{~m}^{2} / \mathrm{g}\right)$ - com os valores obtidos para os complexos argila/material carbonoso dos trabalhos de Franco (valores de sorção entre e $25 \mathrm{mgAM} / \mathrm{g}$ de complexo a $102 \mathrm{mgAM} / \mathrm{g}$ de complexo, para os compósitos formados por argila e sacarose) e Raimundo(valores de sorção entre e $20 \mathrm{mgAM} / \mathrm{g}$ de complexo a $120 \mathrm{mgAM} / \mathrm{g}$ de complexo, para os compósitos formados por argila e sacarose) percebe-se que ocorreu uma aumento dos mesmos.

Deve-se observar que o valor de sorção obtido com os compósitos contendo carvão PA foi igual ao do carvão PA, com ganhos possíveis, assim, no custo, uma vez que as bentonitas são mais baratas que os carvões ativados. Outro ganho possível de suma importância seria o potencial ganho em resistência mecânica dos complexos dado o caráter ligante da argila e o reconhecido caráter frágil dos carvões ativos. [Leboda 2000]. 


\subsection{6 - Resistência à compressão}

São mostrados na tabela 21 os resultados da resistência à compressão das amostras preparadas com argila chocolate transformada em sódica e carvão ativado em pó genérico (CAP).

Tabela 26 - valores para a resistência à compressão das esferas compostas por argila chocolate sódica e carvão ativado em pó.

\begin{tabular}{|c|c|c|c|c|c|}
\hline AMOSTRA & T queima & $\begin{array}{c}\text { Carga } \\
(\mathrm{N})\end{array}$ & $\begin{array}{c}\text { Diâmetro } \\
(\mathrm{mm})\end{array}$ & $\begin{array}{l}\text { Área } \\
\left(\mathrm{mm}^{2}\right)\end{array}$ & $\begin{array}{c}\text { Tensão de } \\
\text { ruptura (MPa) }\end{array}$ \\
\hline 3 & \multirow{2}{*}{$110^{\circ} \mathrm{C}$} & 648 & 22,84 & 409,716 & 1,58 \\
\hline 4 & & 628 & 24,36 & 466,064 & 1,35 \\
\hline 7 & \multirow{2}{*}{350} & 488 & 23,26 & 424,923 & 1,15 \\
\hline 8 & & 747 & 24,78 & 482,274 & 1,55 \\
\hline 10 & \multirow{3}{*}{500} & 638 & 23,92 & 449,379 & 1,42 \\
\hline 11 & & 538 & 23,95 & 450,507 & 1,19 \\
\hline 12 & & 608 & 24,23 & 461,103 & 1,32 \\
\hline 14 & \multirow{3}{*}{700} & 429 & 24,39 & 467,213 & 0,53 \\
\hline 15 & & 418 & 23,90 & 448,628 & 0,93 \\
\hline 16 & & 428 & 24,65 & 477,227 & 0,90 \\
\hline 18 & \multirow{3}{*}{900} & 408 & 24,37 & 466,447 & 0,87 \\
\hline 19 & & 339 & 24,62 & 476,066 & 0,71 \\
\hline 20 & & 488 & 24,73 & 480,329 & 1,02 \\
\hline
\end{tabular}

Examinando-se os dados referentes aos testes de resistência a compressão (tabela 21 e figura 35), nota-se um decréscimo e um aumento constante. Entretanto, no geral a resistência relativa à compressão diminui com o aumento de temperatura do tratamento térmico das amostras. 


\subsection{7 - $\quad$ Espectrofotometria}

A figura 46 apresenta a curva da absorbância das soluções de azul de metileno obtida para várias concentrações $(0,0 ; 0,1 ; 0,2 ; 0,3 ; \mathrm{e} 0,4 ; \mathrm{g} / \mathrm{L}$ de Azul de metileno). Comprimento de onda entre 665 e $670 \mathrm{~nm}$.

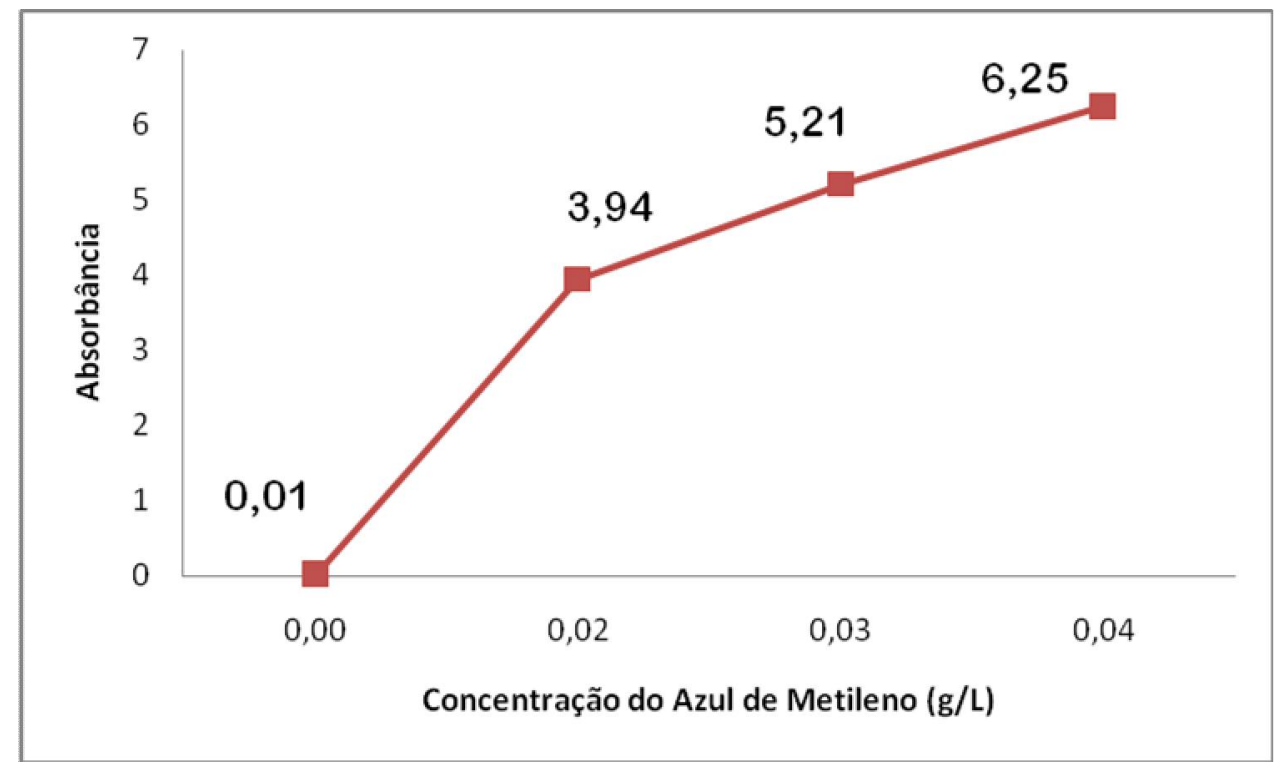

Figura 46 - valores da absorbância do azul de metileno.

A tabela 26 apresenta os valores de absorbância dos sobrenadantes das soluções obtidas no ensaio de adsorção, (descrito no item 4.1.5) medidos para algumas das amostras deste trabalho. 
Tabela 27 - valores da absorbância da argila chocolate e de alguns compósitos argila chocolate/amido, argila chocolate/sacarose e argila chocolate/carvão ativado.

Argila chocolate

\begin{tabular}{c|c}
\hline Amostra & Absorbância \\
\hline $\begin{array}{c}\text { Argila chocolate, } 60^{\circ} \mathrm{C}(120 \mathrm{mgAM} / \mathrm{g} \\
\text { composto })\end{array}$ & 0,138 \\
\hline $\begin{array}{c}\text { Argila chocolate }, 100^{\circ} \mathrm{C}(20 \mathrm{mgAM} / \mathrm{g} \\
\text { composto })\end{array}$ & 0,019 \\
\hline
\end{tabular}

Nanocompósitos de argila chocolate com amido

\begin{tabular}{c|c}
\hline $\begin{array}{c}\text { Argila chocolate/ amido } 10 \%(\mathrm{D}-5) \\
\text { (20mgAM/g composto) }\end{array}$ & 0,067 \\
\hline $\begin{array}{c}\text { Argila chocolate/ amido } 20 \%(\mathrm{ASA}-2) \\
\left(200 \mathrm{mgAM} / \mathrm{g} \text { composto) } 500^{\circ} \mathrm{C}\right.\end{array}$ & 0,026 \\
\hline
\end{tabular}

Nanocompósitos de argila chocolate com sacarose

\begin{tabular}{c|c}
\hline $\begin{array}{c}\text { Argila chocolate/ sacarose } 10 \%(\text { ASS-D) } \\
\text { (20mgAm/g composto) } 500^{\circ} \mathrm{C}\end{array}$ & 0,578 \\
\hline $\begin{array}{c}\text { Argila chocolate/ sacarose } 20 \%(\text { ASS-E) } \\
\text { (200mgAM/g composto) } 500^{\circ} \mathrm{C}\end{array}$ & 0,628 \\
\hline \multicolumn{2}{c}{ Compósitos de argila chocolate com carvão (400mgAM/g de complexo) } \\
\hline 21 & 0,026 \\
\hline 24 & 0,016 \\
\hline 25 & 0,013 \\
\hline 27 & 0,014 \\
\hline 28 & 0,107 \\
\hline 29 & 0,109 \\
\hline
\end{tabular}

Comparando os valores de absorbância obtidos (entre os comprimentos de onda 665 e $675 \mathrm{~nm}$ ) para as amostras deste trabalho, com os valores para as diferentes concentrações das soluções aquosas de Azul de metileno (figura 46), percebe-se que a concentração do Azul de metileno é muito pequena, o que significa que ocorreu a adsorção do mesmo pelos compósitos acima citados, validando o método de avaliação da capacidade de sorção de azul de metileno utilizado neste trabalho. 


\subsection{8 - Área Superficial Específica}

A maioria dos artigos que discutem a área superficial especifica dos carvões apresenta faixas de valores, normalmente entre $300 \mathrm{~m}^{2} / \mathrm{g}$ e $1500 \mathrm{~m}^{2} / \mathrm{g}$. Nguyen-Thanh, 2006, obteve material carbonoso, a partir de moldes negativos, com área superficial específica de $793 \mathrm{~m}^{2} / \mathrm{g}$. Mediu-se, apenas a área superficial específica da amostra argila/carvão PA, $75 \%$ em carvão e queimada a $500^{\circ} \mathrm{C}$. O valor obtido foi de $695 \mathrm{~m}^{2} / \mathrm{g}$. O que mostra que o compósito formado entre a argila chocolate e o carvão apresenta uma alta área superficial específica, comparável a de muitos carvões ativos comerciais. 


\section{CONCLUSÕES}

Com base na análise dos resultados obtidos chegou-se as seguintes conclusões:

- Os melhores resultados de adsorção foram dos compósitos formados por argila chocolate sódica e carvão ativado P.A.

- Os compósitos formados por argila chocolate sódica e amido e por argila chocolate sódica e sacarose apresentaram um aumento significativo da capacidade de adsorção quando a argila utilizada foi submetida a temperatura menor, $60^{\circ} \mathrm{C}$, e, a adição.

- Assim, a análise dos resultados apresentados neste trabalho mostra que:

f É possível obter-se nanocompósitos partindo-se das matérias-primas argila chocolate sódica e amido, argila chocolate sódica e sacarose, argila chocolate sódica e carvão ativado em pó.

f A capacidade adsortiva dos complexos argila/material carbonáceo depende dos parâmetros utilizados durante o processo de obtenção do material.

- Com relação aos testes de resistência a compressão nos compósitos argila/carvão ativado, atingiu-se valores maiores que 1,0 MPa para a tensão de ruptura das esferas. Desta maneira, aliado ao seu poder de sorção similar ao de carvão ativo, pode-se acreditar que estes compósitos apresentam potencial de uso como materiais adsorventes e em filtros cerâmicos. 


\section{REFERÊNCIAS DA LITERATURA}

ALBANEZ, N. E. F. K. Obtenção de óxido de cério com alta área superficial específica. Dissertação de Mestrado. Área de Tecnologia Nuclear Básica. Instituto de Pesquisas Energéticas e Nucleares. IPEN/USP. 1996.

ALBANEZ, N. E. F. K.; DÍAZ, F. R. V. Preparação e caracterização de material compósito argila bentonita / carvão ativado. In: 4th International Conference on Science and Technology of Composite Materials. Rio de Janeiro. Dez, 912. 2007.

AVELLA, M.; DE VLIEGER, J. J.; ERRICO, M. E.; FISCHER, S.; VACCA, P.; VOLPE, M. G. Biodegradable Starch/Clay Nanocomposite Films for Food Packaging Applications. Food Chemistry, 93, 467-474 2005.

BAGREEV, A., BANDOSZ, T. J., LOCKE, D. C. Pore structure and surface characteristics of adsorbents obtained by pyrolisis of sewage sludge-derived fertilizer. Carbon, 39 (13), 1971-1979, 2001.

BANDOSZ, T. J., Carbon, 37, 483, 1999.

BATISTA, T. Estudo das interações entre o corante catiônico azul de metileno e partículas de argila em suspensão aquosa. Processos de migração entre partículas. Dissertação de mestrado apresentada ao Instituto de Química de São Carlos da Universidade de São Paulo. São Carlos. 2006.

BOLGER, R. Foundry Minerals. Industrial Minerals, 351. 29-39, 1996.

BRENNAN, J. K.; BANDOSZ, T. J.; THOMSON, K. T.; GUBBINS, K. E. Water in Porous Cabon. Colloids and Surface. A: Physicochemical and Engineering Aspects. 539-568, 2001.

BRUNAUER, S. EMMET, P. H. e TELLER, E. Adsorption of gases in multimolecular layer. J. Amer. Chem. Soc., 60. 309-319, 1938. 
CARR, L. G. Desenvolvimento de Embalagens Biodegradável tipo Espuma a partir de Fécula de Mandioca. Tese de Doutorado. Escola Politécnica da Universidade de São Paulo. São Paulo, 2007.

CHAARI, I., FAKHFAKH, E., CHAKROUN, S., BOUZID, J., BOUJELBEN, N, FEKI, M., ROCHA, F. JAMOUSSI, F. Lead Removal from Aqueous Solutions by a Tunisian Smectitic. J ournal of Hazardous Materials, 2007 (avaliado em 31/12/2007).

CHEN, B.; EVANS, J. R. G. Thermoplastic Starch-Clay Nanocomposites and their Characteristics. Carbohydrate Polymers, 61, 455-463, 2005.

CHEN, M.; CHEN, B.; EVANS, J. R. G. Novel Thermoplastic Starch-Clay Nanocomposites Foams. Nanotechnology, 16, 2334-2337, 2005.

CHIOU, B.; YEE, E.; GLENN, G. M.; ORTS, W. J. Rheology of starch-clay nanocomposites. Carbohydrate Polymers, 59, 467-475, 2005.

CORRADINI, E.; LOTTI, C.; MEDEIROS, E. S.; CARVALHO, A. J. F.; CURVELO, A. S.; MATTOSO, L. H. C. Estudo comparativo de amidos termoplásticos derivados do milho com diferentes teores de amilose. Polímeros, 15, 2005.

CORTÉS, G. R. M. Contribuição ao Conhecimento de Argilas de Cuba. Dissertação de Mestrado apresentada ao Departamento de Engenharia de Minas da Escola Politécnica de Engenharia da Universidade de São Paulo. São Paulo. 1998.

COSIN, S.: KOZIEVITCH, V.F.J.; SOUZA-SANTOS, P.; VALENZUELA-DÍAZ, F.R. Resistência à corrosão de compósitos mineral/material carbonoso.In: 47 Congresso Brasileiro de Cerâmica. 2352-2359. João Pessoa, PB. 2003. http://www.abceram.org.br/asp/47cbc artigo.asp?cod=476

DEAN, K.; YU, L.; WU, D. Y. Preparation and Characterization of MeltExtruded Thermoplastic Starch/Clay Nanocomposites. Composites Science and Technology, 67, 413-421, 2007. 
FAJULA F.; GALARNEAU, A. E DI RENZO, F. Advanced porous materials: New developments and emerging trends. Microporous and Mesoporous Materials, 82, 227-239, 2005.

FOSTER, M. D. The Relation between composition and swelling in clays. Proceedings of 3td Nat. Conf. On Clays and Clay Minerals, NAS Pub. 395, 205, 1955.

FRANCO, J. H. R. Obtenção e Caracterização de Complexos Mineral/Material Carbonoso Partindo-se de Refugo da Indústria de Óleos, de Argila Esmectítica e de Sílica Gel. Dissertação de Mestrado. Escola Politécnica da Universidade de São Paulo. São Paulo. 2003.

GOPINATH, T. R., CRUZ, V. C. A. E FREIRE, J. A. Estudo Comparativo da Composição Química e as variedades de argilas bentoníticas da região de Boa Vista, Paraíba. Revista de Geologia, 16 (1), 2003.

GRIM, R. E. Bentonites: Geology, Mineralogy, Properties and Uses. Elsevier, Amsterdam, 1978.

GUILARDUCI, V. V. S.; MESQUITA, J. P.; MARTELLI, P. B. E GORGULHO, H. F. Adsorção de fenol sobre carvão ativado em meio alcalino. Química Nova, 29, 1226-1232, 2006.

HARRIES-REES, K. Minerals in waste and effluent treatment. Industrial Minerals. 29-39. 1993.

JOSÉ, C. L. V. Obtenção e caracterização de argilas organofílicas preparadas em laboratório para adsorção de compostos fenólicos, visando seu uso no controle ambiental de poluentes industriais. Tese de doutorado apresentada ao Departamento de Engenharia Química da Escola Politécnica de Engenharia da Universidade de São Paulo. São Paulo, 2003.

KAMPEERAPAPPUM, P.; AHT-ONG, D.; PENTRAKOON, D.; SRIKULKITI. Preparation of Cassava Starch/Montmorillonite Composite Film. Carbohydrate, 67, 155-163, 2007.

LAROTONDA, F. S.; MATSUI, K. N.; SOLDI,V.; LAURINDO, J. B. Biodegradable Films made from raw and acetylated cassava starch. Brazilian Archivies of Biology and Technology, 47, 477-484, 2004. 
LEBODA R. Carbon mineral adsorbents- New type of sorbents. Surface properties and methods of their modification. Materials Chemistry and Physics, 34(2), 123-141, 1993.

LEBODA, R.; TUROV, V.V.; CHARMAS, B.; SKUBISZEWSKA-ZIEBA, J.; GUNKO, V.M. Surface properties of mesoporous carbon-silica gel adsorbents. J ournal of Colloid and Interface Science, 223, 112-125, 2000.

LEBODA, R.; CHARMAS, B. Evaluation of surface area of carbon component of model carbon-silica adsorbents from adsorption data of p-nitrophenol from aqueous solutions. Colloid and Surfaces. A. Physicochemical and Engineering Aspects, 135, 267-275, 1998.

LI, A .; Chang, J.; Wang, A. Utilization of Starch and Clay for the Preparation of Superabsorbent Composite. Bioresource Technoloy, 98, 327-332, 2007.

LUNA, F. J. E SCHUCHARDT, U. Argilas Pilarizadas - Uma Introdução. Química Nova, 22 (1) 1999.

MARCHETTO, M., FERREIRA Fo, S. S., Eng. Sanit. Ambient., 10, 243, 2005.

MELLO, P. H. Estudo teórico sobre corantes catiônicos e possíveis modelos que expliquem a interação com a agila do tipo montmorilonita. Tese de Doutorado apresentada ao Instituto de Química de São Carlos da Universidade de São Paulo. São Carlos. 2006.

NAMASIVAYAM, C., DINESH KUMAR, M., SELV I, K., ASHRUFFUNISSA BEGUM, R., VANATHI, T., YAMUNA, R. T., Biomass \& Bioenergy, 21, 477, 2001.

NAMASIVAYAM, C MARCHETTO, M., FERREIRA Fo, S. S. Eng. Sanit. Ambient, 10, $243,2005$.

NEUMANN, M. G., GeSSNER, F, CIONE, A. P. P., SARTORI, R. A. E CAVALHEIRO, C. C. S. Interações entre corantes e argilas em suspensão aquosa. Química Nova, 23(6), 2000. 
NGUYEN-THANH, D.; BANDOSZ, T. J. Metal-loaded carbonaceous adsorbents template from porous clay heterostructures. Microporous and Mesoporous Materials. 92, 47-55, 2006.

O'DRISCOLL, M. European Cat Litter. Industrial Minerals, 46-65, 1992.

OKADA, K., YAMAMOTO, N., KAMESHIMA, Y., YASUMORE, A. Adsorption properties of activated carbon from waste newspaper prepared by chemical and physical activation. J. of Colloid and Interface Science, 262(1), 194-199, 2003.

PATRICK J. W. Porosity in carbons: Characterization and application, John Wilwy \& Sons, New York, 1995.

PEREIRA, K. R. O. Estudo, em escala de laboratório, do uso de argilas do tipo bofe na obtenção de argilas organofílicas e ativadas. Tese de Doutorado. Escola Politécnica. Departamento de Engenharia Metalúrgica e de Materiais. Universidade de São Paulo. 2008.

PRENTICE, J. E. "Geology of Construction Materials". Topics in the Earth Science. Emeritus Profesor of Geology. University of London. 1990.

PIYPORN, K.; DUANGDAO, A.; DUANGHATHAI, P.; KAWEE, S. Preparation of cassava starch/montmorillonite composite film. Carbohydrate, 67 , 155-163, 2007.

RAIMUNDO, D. R. Obtenção e caracterização de nanocompósitos argilomineral/material carbonos. Dissertação de Mestrado. Escola Politécnica da Universidade de São Paulo. 2004.

RAY, S. S.; BOUSMINA, M. Biodegradable polymers and their layered silicate nanocomposites: In: Greening the 21 st century materials world. Progress in Materials Science, 50, 962-1079, 2005.

RECK, R. A. Quaternary ammonium compounds. Kirk Othmer's Encyclopedia of Chemical Technology, 3를 ed. V. 19, p. 521. 1992.

RODRIGUES, M. G. F., PEREIRA, K. R. O., VALENZUELA-DIAZ, F. R. Cerâmica, 5, 2006. 
RODRIGUES, M. G. F.; SILVA, M. L. P.; SILVA, M. G. C. Caracterização da Argila bentonítica para utilização na remoção de chumbo de efluentes sintéticos. Cerâmica. 50. 315. 2004.

RODRIGUES, S.; SANTOS, P. S.. O "Sistema Argila+Água”. Cerâmica. 24. 101. 1978.

ROMERO, M. G. Bentonita. Disponível em: www.ucm.es/info/crismine/ Acesso em 18/01/2006.

ROMERO, M. G. Bentonita. Disponível em: www.ucm.es/info/crismine/ Acesso em 18/01/2006.

SAEED, A. Bentonite in animal feed. Industrial Minerals, 346, 47-51, 1996.

SANTARÉM, J. European market development for absorbent clays. 304, 3547, 1993.

SAN MIGUEL-SAN MIGUEL, G., FOWLER, G. D., SOLLARS, C. J., A study of the characteristics of activated carbons produced by steam and carbon dioxide activation of waste tyre rubber. Carbon, 41(50), 1009-1016, 2003.

SCHETTINO JR. M. A. ; FREITAS, J. C. C.; CUNHA, A. G. E EMMERICH, F. G. Preparação e Caracterização de carvão ativado quimicamente a partir da casca de arroz. Química Nova, vol. XY, 1, 200, 2007.

SILVA, A. A. Estudo de Argilas Organofílicas Destinadas à Separação Óleo/Água. Dissertação de Mestrado. Centro de Ciências e Tecnologia. Universidade Federal de Campina Grande. Paraíba. 2005.

SOUZA, SANTOS, P. Ciência e Tecnologia de Argilas. 2 ed. São Paulo, Ed. Edgar Blucher Ltda, 1992.

TRINDADE, H. P. A. Bentonita, em Sumário Mineral Brasileiro, 2000, Departamento Nacional de Produção Mineral, Brasília,. p. 31-32, 2001.

SOUZA, SANTOS, P. Ciência e Tecnologia de Argilas. 2 ed. São Paulo, Ed. Edgar Blucher Ltda, 1992. 
TRINDADE, H. P. A. Bentonita, em Sumário Mineral Brasileiro, 2000, Departamento Nacional de Produção Mineral, Brasília,. p. 31-32, 2001.

VALENZUELA-DIAZ, F. R. Estudos Reológicos de Dispersões contendo Matérias-Primas Cerâmicas. Sistema Bentonita Sigma, Água - Sacarose. In: Congresso Brasileiro de Engenharia e Ciência dos Materiais, 14, São Paulo, 2001.

VALENZUELA-DIAZ, F. R. Preparação, a nível de laboratório, de algumas argilas esmectíticas organofílicas. Tese de Doutoramento. Departamento de Engenharia Química da Escola Politécnica da Universidade de São Paulo. 1994.

VALENZUELA-DIAZ, F. R. SANTOS, P. S E SANTOS, H. S.; A importância das argilas industriais brasileiras. Química Industrial, 44, 31 - 37, 1992.

WILHELM, H. M. SIERAKOWSKI, M. R. SOUZA, G. P.; WYPYCH, F. Starch Films Reinforced with Mineral Clay. Carbohydrate Polymers, 52, 101-110. 2003.

WRIGHT, F. B. Bentonites markets. Industrial Minerals, 43-52, 1992.

VALENZUELA-DIAZ, F. R. SANTOS, P. S E SANTOS, H. S.; A importância das argilas industriais brasileiras. Química Industrial, 42, 33-37, 1992

SITES:

Disponível em: www. quimica.ufpr.br. Acesso em 20/10/07

Disponível em http://en.wikipedia.org/wiki/charcoal. Acesso em 20/10/07.

Disponível em : http://pubs.usgs.gov/of/2001/of01-041/htmldocs/clays/smc.htm; acesso em 27/11/07.

Disponível em:

http://sbrtv1.ibict.br/upload/sbrt2992.pdf?PHPSESSID=6aa56910df57f5c60f1bee9de0d eeaf0. Acesso em 19/02/08. 
Disponível em: http://pubs.usgs.gov/of/2001/of01-041/htmldocs/clays/smc.htm. Acesso em 27/11/07.

Disponível em:

www.deq.ufpe.br/.../Processos\%20Químicos\%20de\%20Tratamento\%20de\%20Efluente s/Fundamentos\%20de\%20Adsorcao.doc. Acesso em 27/11/07. 


\section{SUGESTÕES PARA TRABALHOS FUTUROS}

Para continuação deste estudo, sugerimos as seguintes pesquisas:

- Aprofundar os estudos referentes à obtenção de nanocompósitos argila/amido de milho, variando os parâmetros de processo, como as condições de adição do amido e adição de outras substâncias (plastificante).

- Estudar outras porcentagens de carvão ativado em relação à massa de argila e os parâmetros de adição do pó na dispersão de argila, como tempo, temperatura e proporção de água na dispersão.

- Fazer ensaios de adsorção de poluentes orgânicos de compostos fenólicos industriais.

- Estudar a obtenção de nanocompósitos com a argila chocolate e outros compostos carbonosos, como por exemplo, lodo de tratamento de águas residuárias. 